Kis Boglárka Mercedesz (Orcid ID: 0000-0003-4458-1639)

Caracausi Antonio (Orcid ID: 0000-0003-2510-2890)

Palcsu László (Orcid ID: 0000-0002-6542-7537)

Sciarra Alessandra (Orcid ID: 0000-0003-3767-3105)

\title{
Noble gas and carbon isotope systematics at the seemingly inactive Ciomadul volcano (Eastern-Central Europe, Romania): evidence for volcanic degassing
}

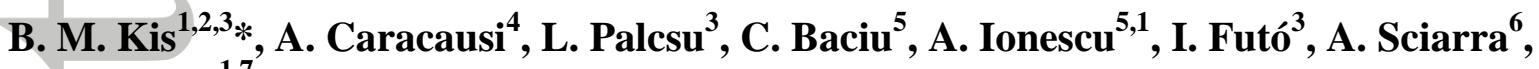 \\ Sz. Harangi ${ }^{1,7}$
}

1. MTA-ELTE Volcanology Research Group, H-1117 Budapest, Pázmány sétány 1/C,

Hungary, szabolcs.harangi@geology.elte.hu

2. Babes-Bolyai University, Faculty of Biology and Geology, Kogalniceanu 1, Romania, kis.boglarka@ubbcluj.ro

3. Isotope Climatology and Environmental Research Centre, Institute for Nuclear Research,

Hungarian Academy of Sciences, H-4026 Debrecen, Bem tér 18/C, Hungary,

palcsu.laszlo@atomki.mta.hu, futo.istvan@atomki.mta.hu

4. Istituto Nazionale di Geofisica e Vulcanologia, Sezione Palermo, IT-90146 Palermo, Via Ugo La Malfa 153, Italy, antonio.caracausi@ingv.it;

5. Babes-Bolyai University, Faculty of Environmental Science and Engineering, RO-400294

Cluj-Napoca, Fântânele 30, Romania, artur.ionescu@ubbcluj.ro, calin.baciu@ubbcluj.ro

6. Istituto Nazionale di Geofisica e Vulcanologia, Sezione Roma 1, IT-00143 Roma, Via V.

Murata 605, Italy, alessandra.sciarra@ingv.it

7. Department of Petrology and Geochemistry, Eötvös Loránd University, Budapest, Hungary

Correspondingauthor:B.M. Kis (kis.boglarka@ubbcluj.ro, kisboglarka85@gmail.com)

Key Points:

- $\mathrm{CO}_{2}$ emissions at Ciomadul, Eastern-Central Europe, suggest a still-active plumbing system beneath the volcano in spite of long dormancy.

- The $\mathrm{CO}_{2}$ and $\mathrm{He}$ isotope compositions provide evidence for significant contribution of magma-derived volatiles, up to $80 \%$.

- Isotopic signatures of gases indicate that primary magmas could have derived from a mantle source modified by subduction-related fluids.

This article has been accepted for publication and undergone full peer review but has not been through the copyediting, typesetting, pagination and proofreading process which may lead to differences between this version and the Version of Record. Please cite this article as doi: $10.1029 / 2018 \mathrm{GC008153}$

(C) 2019 American Geophysical Union. All rights reserved. 


\section{Abstract}

Ciomadul is the youngest volcano in the Carpathian-Pannonian Region, Eastern-Central Europe, which last erupted $30 \mathrm{ka}$. This volcano is considered to be inactive, however, combined evidence from petrologic and magnetotelluric data, as well as seismic tomography studies suggest the existence of a subvolcanic crystal mush with variable melt content. The volcanic area is characterized by high $\mathrm{CO}_{2}$ gas output rate, with a minimum of $8.7 \times 10^{3} \mathrm{t} \mathrm{yr}^{-}$ ${ }^{1}$. We investigated 31 gas emissions at Ciomadul to constrain the origin of the volatiles. The $\delta^{13} \mathrm{C}^{-} \mathrm{CO}_{2}$ and ${ }^{3} \mathrm{He} /{ }^{4} \mathrm{He}$ compositions suggest the outgassing of a significant component of mantle-derived fluids. The He isotope signature in the outgassing fluids (up to $3.10 R_{a}$ ) is lower than the values in the peridotite xenoliths of the nearby alkaline basalt volcanic field $\left(\mathrm{R} / \mathrm{R}_{\mathrm{a}}\right.$ 5.95Ra \pm 0.01$)$ which are representative of a continental lithospheric mantle and significantly lower than MORB values.

Considering the chemical characteristics of the Ciomadul dacite, including trace element and $\mathrm{Sr}-\mathrm{Nd}$ and $\mathrm{O}$ isotope compositions, an upper crustal contamination is less probable, whereas the primary magmas could have been derived from an enriched mantle source. The low $\mathrm{He}$ isotopic ratios could indicate a strongly metasomatized mantle lithosphere. This could be due to infiltration of subduction-related fluids and postmetasomatic ingrowth of radiogenic He.

The metasomatic fluids are inferred to have contained subducted carbonate material resulting in a heavier carbon isotope composition $\left(\delta^{13} \mathrm{C}\right.$ is in the range of -1.4 to $-4.6 \%$ ) and an increase of $\mathrm{CO}_{2} / 3 \mathrm{He}$ ratio. Our study shows the magmatic contribution to the emitted gases.

\section{Plain Language Summary}

Determining the fluxes and composition of gases in active and dormant volcanoes could help to constrain their origin. Ciomadul is the youngest volcano of the Carpathian-Pannonian Region, Eastern-Central Europe, where the last eruption occurred $30 \mathrm{ka}$. Its eruption chronology is punctuated by long quiescence periods (even $>100$ kyrs) separating the active phases; therefore, the long dormancy since the last eruption (30 ka) does not unambiguously indicate inactivity. Knowing if melt-bearing magma resides in the crust is fundamental to evaluate the nature of the volcano. Isotopic compositions of helium $\left({ }^{3} \mathrm{He} /{ }^{4} \mathrm{He}\right)$ and carbon $\left(\delta^{13} \mathrm{C}_{\mathrm{CO} 2}\right)$ are important tools for the study of the origin of the gases. We show that the isotope variation of the emitted gases suggests a metasomatised lithospheric mantle origin for the primary magmas. This is consistent with a degassing deep magma body existing beneath Ciomadul and that this long-dormant volcano cannot be considered as extinct.

\section{Introduction}

Gas emissions are often associated with active or dormant volcanic areas and regions affected by extensional tectonics (e.g., O'Nions \& Oxburgh, 1988, Oppenheimer et al., 2014). Monitoring of fluids (chemical and isotopic compositions and physical properties) in volcanic regions provides important information concerning the processes occurring at depth (e.g., Edmonds, 2008; Fischer, 2008; Christopher et al., 2010; Mazot et al., 2011; Ruzié et al., 2012; Agusto et al., 2013; Barry et al., 2013, 2014; Caliro et al., 2015; Roulleau et al., 2016; Tassi et al., 2010, 2011, 2016; Wei et al., 2016). The chemical and isotopic composition of the emitted fluids in active volcanoes is primarily controlled by magmatic processes, such as the injection of new magma into the plumbing system or degassing of deep mafic magma in the lower crust, or interaction with the volcanic hydrothermal systems, among others (e.g., 
Caracausi et al., 2003, 2013; Edmonds, 2008; Christopher et al., 2010; Paonita et al., 2012, 2016; Sano et al., 2015). Furthermore , compositional change of the fluids may also correlate with the seismicity at regional scale (e.g., Chiodini et al., 2004; Bräuer et al., 2008; 2018; Melián et al., 2012, Cardellini et al., 2017).

There has been major progress in understanding the factors controlling gas emissions in active and dormant volcanic areas during the last two decades (Aiuppa et al., 2007; Edmonds, 2008; Oppenheimer et al., 2014; Lee et al., 2016; Moussallam et al., 2018); however, much less attention has been given to seemingly inactive volcanic areas (Roulleau et al., 2015). These are volcanoes that last erupted more than $10 \mathrm{ka}$ and at the surface there are no signs of reawakening. The Tatun volcanic complex in Taiwan is an example of such a volcanic system. Although the last eruption occurred $20 \mathrm{ka}$, geophysical data indicates a stillactive magma storage. The composition of emitted gases is consistent with this interpretation, as they contain significant magmatic components (Roulleau et al., 2015). The importance and the potential hazard of such volcanoes are shown by the case of the Ontake volcano in Japan. There were no proven records of historical and even Holocene eruptions before the phreatic eruptive event in 1979 and therefore, there were no detailed studies and monitoring on this volcano. In 2014, another phreatic eruption occurred, causing serious fatalities (Kato et al., 2015) and pointed to the requirement to better understand such long-dormant volcanoes. Sano et al., (2015) demonstrated that regular monitoring of volcanic gases is fundamental to understand the behaviour of these apparently inactive volcanoes. In this regard, detection of a magmatic chamber containing some melt fraction could mean the potential for reactivation even after several tens of kyrs dormancy. Emission of gases with isotopic signatures in the range of magmatic values can be evidence of magma intrusions at depth (Farrar et al., 1995; Sorey et al., 1998; Pizzino et al., 2002; Carapezza et al., 2003, 2012; Carapezza \& Tarchini, 2007; Bräuer et al., 2008; 2018; Caracausi et al., 2013, 2015; Fischer et al., 2014; Rouwet et al., 2014, 2017; Sano et al., 2015), in addition to recognition of geophysical anomalies reflecting melt pockets at depth (Comeau et al., 2015; 2016; Harangi et al., 2015a).

Ciomadul is the youngest volcano within the Carpathian-Pannonian Region, EasternCentral Europe, where the last eruption occurred 30 ka (Harangi et al., 2010; 2015b; Molnár et al., 2019). Thus, it is usually considered as an inactive volcano. In spite of its long dormancy, combined evidence from petrologic and magnetotelluric data (Kiss et al., 2014; Harangi et al., 2015a), as well as seismic tomography (Popa et al., 2012) suggest the presence of a melt-bearing crystal mush beneath the volcano. This is consistent with the local high heat flow $\left(85-120 \mathrm{~mW} / \mathrm{m}^{2}\right)$ compared to the Carpathian Range where this value decreases to $40-60$ $\mathrm{mW} / \mathrm{m}^{2}$ (Demetrescu \& Andreescu, 1994, Horváth et al., 2006), the high flux of carbondioxide of $8.7 \times 10^{3} \mathrm{t} \mathrm{yr}^{-1}$ (Kis et al., 2017) the presence of mineral and thermal waters up to $78^{\circ} \mathrm{C}$ (Jánosi, 1980; Rădulescu et al., 1981) and the geodynamically active region (Wenzel et al., 1999; Ismail-Zadeh et al., 2012). The eruption chronology of the Ciomadul lava dome field (Molnár et al., 2018) is characterized by prolonged quiescence periods between the active phases, often exceeding 100 kyrs.

There are a number of sites at Ciomadul, where significant amount of $\mathrm{CO}_{2}$ gases are emitted (Kis et al., 2017). Althaus et al. (2000), Vaselli et al. (2002), Frunzeti (2013) and Sarbu et al (2018) studied the composition of gases collected from a few locations and concluded that they could indicate a deep-seated magma body below the volcano. Here, we present a comprehensive helium isotope signature (hereafter ${ }^{3} \mathrm{He} /{ }^{4} \mathrm{He}$ ) and carbon isotope (hereafter $\delta^{13} \mathrm{C}_{\mathrm{CO} 2}$ ) systematics of the volatile degassing from Ciomadul based on a detailed sampling of all the main known locations of gas emissions to constrain the origin of fluids and to characterize the nature of a seemingly inactive volcano. 


\section{Geological setting}

\subsection{Ciomadul Volcanic Dome Field}

Ciomadul volcano is located at the southeastern edge of the Carpathian-Pannonian Region, at the southern end of the Călimani-Gurghiu-Harghita volcanic chain (Szakács et al, 1993, Szakács \& Seghedi, 1995; Pécskay et al., 2006; Figure 1). It is part of a postcollisional volcanic belt, which comprises a series of andesitic to dacitic volcanoes, developed parallel with the Carpathian orogeny. The volcanism occurred well after the continent-continent collision between the Tisza-Dacia microplate and the western margin of the Eurasian plate (Csontos et al., 1992; Matenco and Bertotti 2000, Cloetingh et al, 2004; Seghedi et al., 2004; 2005; 2011; Matenco et al, 2007). Ciomadul is part of a lava dome field and this central volcanic complex involves $8-14 \mathrm{~km}^{3}$ of high-K dacitic lavas (Karátson \& Timár, 2005, Szakács et al, 2015; Molnár et al., 2019). The volcano developed on the Early Cretaceous clastic flysch sedimentary unit of the Eastern Carpathians that forms several nappes. It consists of binary alternation of sandstones, calcareous sandstones, limestones and clays/marls from the Sinaia Formation of the Ceahlau nappe and the Bodoc flysch (Băncilă, 1958; Ianovici \& Radulescu, 1968; Nicolăescu, 1973; Grasu et al., 1996). The flysch unit has a thickness up to $2500 \mathrm{~m}$.

The Ciomadul volcanic complex is made up by amalgamation of several lava domes truncated by two explosion craters called Mohos and Saint Anna (Szakács et al., 2015). This central volcano is surrounded by further isolated lava domes (Baba Laposa, Haramul Mic, Dealul Mare, Büdös-Puturosul and Bálványos; Molnár et al., 2018, Figure 2). Volcanism at the Ciomadul volcanic dome field started around $1 \mathrm{Ma}$, while the most voluminous Ciomadul volcanic structure has developed over the last ca. 160 kyr (Molnár et al., 2018; 2019). During the first volcanic stage, the intermittent lava dome extrusions were separated by relatively long dormant periods even exceeding $100 \mathrm{kyr}$. The second volcanic stage was characterized by initial lava dome effusion and then, after ca. 40 kyrs of quiescence, a more explosive volcanic activity occurred (from 57 to 30ka, Moriya et al, 1995, 1996; Vinkler et al, 2007; Harangi et al., 2010, 2015b; Karátson et al., 2016; Molnár et al., 2018; 2019). This stage involved lava-dome collapse events, vulcanian and sub-plinian to plinian explosive eruptions (Vinkler et al, 2007; Harangi et al., 2015b; Karátson et al., 2016). The eruptive products are relatively homogeneous K-rich dacites (Szakács and Seghedi, 1987; Szakács et al., 1993; Vinkler et al., 2007; Molnár et al., 2018; 2019). Petrogenetic and thermobarometric studies on amphiboles as well as combined U-Th/He and U/Th zircon dating suggest the presence of a long-lasting (up to $350 \mathrm{kyrs}$ ) crystal mush body in the crust. This appears to be mostly at relatively low-temperature just above the solidus $\left(700-750^{\circ} \mathrm{C}\right)$ and is periodically partly remobilized by injections of fresh basaltic magmas that could rapidly trigger volcanic eruptions (Kiss et al., 2014; Harangi et al., 2015a; 2015b).

The Ciomadul volcano is located near $(\sim 50 \mathrm{~km})$ the Vrancea seismic region (Wenzel et al., 1999; Ismail-Zadeh et al., 2012) located at the arc bend between the Eastern and the Southern Carpathians. Frequently occurring earthquakes have deep hypocentres (70-170 km) delineating a narrow, vertical region. This is consistent with a high-velocity seismic anomaly interpreted as a cold lithosphere slab descending slowly into the asthenospheric mantle (Wortel \& Spakman, 2000). Further crustal and subcrustal earthquakes $(M<4)$ occur occasionally around the Perșani basalt volcanic field and the Ciomadul volcano (Popa et al., 2012). The seismic tomographic model indicates a vertically-extended low-velocity anomaly beneath Ciomadul. This can be interpreted as trans-crustal magma storage with an upper melt-dominated magma chamber (Popa et al., 2012). The seismic tomographic model is supported by the result of combined petrologic and magnetotelluric studies which 
demonstrated the existence of a low-resistivity anomaly and the depth of 5-20 km beneath the volcanic centers of Ciomadul, inferred to be a melt-bearing crystal mush (Harangi et al., 2015a). In addition, a deeper low-resistivity anomaly was also detected at a depth of 30-40 $\mathrm{km}$, possibly related to a deeper magma accumulation zone at the crust-mantle boundary.

Another Pleistocene monogenetic basalt volcanic field is approximately $40 \mathrm{~km}$ from the Ciomadul, at the southeastern part of the Carpathian-Pannonian Region (Figure 1), at the boundary between the Perşani Mts. and the Transylvanian basin (Seghedi \& Szakács, 1994; Downes et al., 1995; Harangi et al., 2013; Seghedi et al., 2016). Basaltic volcanism occurred here between 1.14 Ma and $683 \mathrm{ka}$ (Panaiotu et al., 2004, 2013) and formed several volcanic centers accompanied by maars, scoriacones and lava flows. The erupted basaltic magma carried significant amount of ultramafic xenoliths from the lithospheric mantle (peridotites and amphibole pyroxenites) revealing the nature of the uppermost mantle of this region (Vaselli et al., 1995; Falus et al., 2008).

\subsection{Gas emissions and mineral water springs at Ciomadul volcanic area}

Gas emanations in the form of bubbling pools and low-temperature $\left(\mathrm{T} \sim 8-10^{\circ} \mathrm{C}\right)$ dry mofettes are characteristic of the Ciomadul volcano. $\mathrm{CO}_{2}$-bubbling peat bogs can be also found, mainly at the north-eastern (Buffogó peat bog) and southern parts of the Puturosul Mts. (Zsombor-Valley, Jánosi et al., 2011). The minimum total $\mathrm{CO}_{2}$ flux was estimated to be $8.7 \times 10^{3} \mathrm{t} \mathrm{yr}^{-1}$ (Kis et al., 2017). The aquifers of this area are represented by $\mathrm{CO}_{2}$-rich sparkling mineral water, with temperature up to $22.5^{\circ} \mathrm{C}$ (Berszán et al., 2009; Jánosi et al., 2011; Italiano et al., 2017).

\section{Sampling and analytical methods}

A total of 31 sites were selected for this study, including bubbling pools, dry gas emissions (mofettes) and one drilling (Figure 2 and Table 1). We collected fluids during two field campaigns carried out in the spring and autumn of 2016 respectively. In the $1^{\text {st }}$ field campaign, gas samples were collected for $\delta^{13} \mathrm{C}-\mathrm{CO}_{2}$ and ${ }^{3} \mathrm{He} /{ }^{4} \mathrm{He}$ composition in 11 evacuated Pyrex glass tubes with a vacuum stop-cock, while for chemical composition, gas samples were collected in $150 \mathrm{ml}$ glass tubes with two vacuum stop-cocks. Chemical compositions were analyzed at the Istituto Nazionale di Geofisica e Vulcanologia, Rome, Italy, whereas chemical and isotopic composition of water, noble gas compositions $(\mathrm{He}, \mathrm{Ne})$ and $\delta^{13} \mathrm{C}-\mathrm{CO}_{2}$ of gas samples were measured at the Isotope Climatology and Environmental Research Centre (ICER), Institute for Nuclear Research, Hungarian Academy of Sciences, Debrecen, Hungary. During the $2^{\text {nd }}$ field campaign, the samples were collected in glass and steel samplers equipped with two valves. These samples were analyzed for their elemental composition ( $\mathrm{He}, \mathrm{Ne}, \mathrm{Ar}, \mathrm{H}_{2}, \mathrm{O}_{2}, \mathrm{~N}_{2}, \mathrm{CO}, \mathrm{CH}_{4}$ and $\left.\mathrm{CO}_{2}\right), \delta^{13} \mathrm{C}\left(\mathrm{CO}_{2}\right),{ }^{3} \mathrm{He} /{ }^{4} \mathrm{He}$ ratios and, ${ }^{20} \mathrm{Ne}$ abundances at the Istituto Nazionale di Geofisica e Vulcanologia, Palermo, Italy.

We also separated clinopyroxene mineral grains (> $3 \mathrm{~g}$ in weight) from one of the lherzolite xenoliths collected at the foot of the Gruiu scoria cone, in the Persani volcanic field. The noble gas composition of the fluid inclusions were analysed at Istituto Nazionale di Geofisica e Vulcanologia, Palermo, Italy. 


\subsection{Chemical and isotopic composition of gases}

The chemical composition of the samples from the $1^{\text {st }}$ campaign was analysed with a Portable Varian CP4900 Micro Gas Chromatograph. This Micro GC is configured for the analysis of $\mathrm{He}, \mathrm{Ne}, \mathrm{H}_{2}, \mathrm{O}_{2}, \mathrm{~N}_{2}$ by means of a molecular sieve 5A (20 meter unheated) column and $\mathrm{CO}_{2}, \mathrm{CH}_{4}$ and $\mathrm{H}_{2} \mathrm{~S}$ by means of a PoraPlot (PPQ 10 meter heated) column. The instrument is equipped with a micro thermal conductivity detector (TCD) responding to the difference in thermal conductivity between the carrier gas (argon) and the sample composition. The detection limit is $1 \mathrm{ppm}$, operating range is from $1 \mathrm{ppm}$ to $100 \%$ level concentrations, and repeatability is $<0.5 \% \mathrm{RSD}$ in peak area at constant temperature and pressure.

For the analysis of $\delta^{13} \mathrm{C}_{\mathrm{CO} 2}$, carbon dioxide was cryogenically removed from the gas samples by liquid nitrogen and measured by Thermo Finnigan Delta ${ }^{\text {PLUS }}$ XP isotope ratio mass spectrometer. Isotope ratios are given in the standard $\delta$ notation in permil (\%o) versus VPDB. Errors for $\delta^{13} \mathrm{C}$ are $0.5 \%$.

Noble gas isotopic ratios $\left({ }^{3} \mathrm{He} /{ }^{4} \mathrm{He}\right.$ and $\left.{ }^{4} \mathrm{He} /{ }^{20} \mathrm{Ne}\right)$ were measured from each gas sample that was inserted into the preparation line of the VG5400 noble gas mass spectrometer. The argon and the other chemically active gases $\left(\mathrm{N}_{2}, \mathrm{CO}_{2}\right.$ etc.) were separated in a cryogenic cold system consisting of two cold traps and were adsorbed in an empty trap at $25 \mathrm{~K}$. The $\mathrm{Ne}$ and $\mathrm{He}$ were adsorbed in a charcoal trap at $10 \mathrm{~K}$. He was desorbed at $42 \mathrm{~K}$ and neon at $90 \mathrm{~K}$ and measured sequentially. The measurement procedure was calibrated with known air aliquots. The analytical uncertainties are $1 \%$ for $\mathrm{He}$ concentrations and $5 \%$ for $\mathrm{Ne}$ concentrations and $2.5 \%$ for ${ }^{3} \mathrm{He} /{ }^{4} \mathrm{He} .{ }^{3} \mathrm{He} /{ }^{4} \mathrm{He}$ ratio is expressed as $\mathrm{R} / \mathrm{Ra}$ (being $\mathrm{Ra}$ the $\mathrm{He}$ isotope ratio of air and equal to $1.384 \cdot 10^{-6}$. He isotopic composition was corrected for the atmospheric He contamination $\left(\mathrm{R} / \mathrm{R}_{\mathrm{ac}}\right)$ considering the ${ }^{4} \mathrm{He} /{ }^{20} \mathrm{Ne}$ ratio; $\mathrm{R} / \mathrm{R}_{\mathrm{ac}}=\left[\mathrm{R} / \mathrm{R}_{\mathrm{a}}{ }^{*}(\mathrm{X}-\right.$ 1) $] /(\mathrm{X}-1)$ where $\mathrm{X}$ is the air-normalized ${ }^{4} \mathrm{He} /{ }^{20} \mathrm{Ne}$ ratio taken as 0.318 (Sano \& Wakita, 1985).

For the samples of the second analysis campaign, the chemical and isotopic composition of $\mathrm{He}-\mathrm{Ne}$ and ${ }^{13} \mathrm{C}_{\mathrm{CO} 2}$ was determined in the laboratories of INGV-Palermo.

The concentrations of $\mathrm{CO}_{2}, \mathrm{CH}_{4}, \mathrm{O}_{2}$ and $\mathrm{N}_{2}$ were analysed using an Agilent 7890B gas chromatograph with Ar as carrier and equipped with a 4-m Carbosieve S II and PoraPlot$\mathrm{U}$ columns. A TCD detector was used to measure the concentrations of $\mathrm{He}, \mathrm{O}_{2}, \mathrm{~N}_{2}$ and $\mathrm{CO}_{2}$ and a FID detector for $\mathrm{CO}$ and $\mathrm{CH}_{4}$. The analytical errors were $10 \%$ for $\mathrm{He}$ and $5 \%$ for $\mathrm{O}_{2}$, $\mathrm{N}_{2}, \mathrm{CO}, \mathrm{CH}_{4}$ and $\mathrm{CO}_{2}$. More details on the analytical procedures used during this analysis are given in Liotta \& Martelli (2012).

The carbon isotopic composition of $\mathrm{CO}_{2}\left(\delta^{13} \mathrm{C}_{\mathrm{CO} 2}\right)$ was determined using a Thermo Delta XP IRMS equipped with a Thermo Scientific ${ }^{\mathrm{TM}}$ TRACE ${ }^{\mathrm{TM}}$ Ultra Gas Chromatograph, and a $30 \mathrm{~m}$ Q-plot column (i.e. of $0.32 \mathrm{~mm}$ ). The resulting $\delta^{13} \mathrm{C}_{\mathrm{CO} 2}$ values are expressed in \%o with respect to the international V-PDB (Vienna Pee Dee Belemnite) standard and analytical uncertainties are $\pm 0.15 \%$. The method for the $\delta^{13} \mathrm{C}$ determination of Total Dissolved Carbon (TDC) is based on chemical and physical $\mathrm{CO}_{2}$ stripping (Capasso et al., 2005a). Isotopic ratios were measured using a Finnigan Delta Plus Mass Spectrometer. The results are expressed in \%o of the international V-PDB standard. The standard deviations of the ${ }^{13} \mathrm{C} /{ }^{12} \mathrm{C}$ ratios are $\pm 0.2 \%$.

${ }^{3} \mathrm{He},{ }^{4} \mathrm{He}$ and ${ }^{20} \mathrm{Ne}$ and the ${ }^{4} \mathrm{He} /{ }^{20} \mathrm{Ne}$ ratios were determined by separately inserting $\mathrm{He}$ and $\mathrm{Ne}$ into a split flight tube mass spectrometer (GVI-Helix SFT, for He analysis) and into a multi-collector mass spectrometer (Thermo-Helix MC plus, for Ne analysis), after standard purification procedures (Rizzo et al., 2015). The analytical reproducibility was $<0.1 \%$ for ${ }^{4} \mathrm{He}$ and ${ }^{20} \mathrm{Ne}$. However, the estimation of $\mathrm{He}$ and $\mathrm{Ne}$ concentration agrees within $10 \%$ uncertainty respect to GC measurements. In this study, the time from sampling to analysis was lower than 
two weeks and results are fully reliable. The analytical error for $\mathrm{He}$ and $\mathrm{Ne}$ concentration measurements is generally below $0.3 \%$.

\subsection{Noble gas isotope data for the Perşani clinopyroxene}

The chosen xenolith is a fresh spinel lherzolite with about $12 \%$ clinopyroxene content. Here, we performed new noble gas analyses. The preparation, single-step crushing and analysis of fluid inclusions was the same as described by Correale et al. (2012) and references therein. Helium $\left({ }^{3} \mathrm{He}\right.$ and $\left.{ }^{4} \mathrm{He}\right)$ isotopes were measured separately by two different split-flight-tube mass spectrometers (Helix SFT-Thermo). The analytical uncertainty of the determination of the TGC and the He, Ne, abundances was $\sim 10 \%$. Error in the ${ }^{3} \mathrm{He} /{ }^{4} \mathrm{He}$ ratios is reported at the $1 \sigma$ level.

\section{Results}

The site, sample names and geographical locations with their GPS coordinates (WGS84, Geographical Coordinates), source type (mofettes or bubbling pools), temperature, $\mathrm{pH}$ and electrical conductivity for bubbling pool samples are presented in Table 1, chemical and isotopic composition are listed in Table 2 and 3. Noble gas isotopic compositions of clinopyroxenes from mantle xenoliths are shown in Table 4.

\subsection{Chemical and isotopic composition of gases}

The $\mathrm{CO}_{2}$ concentration in the collected gases ranges from 6.40 to $98.36 \%$. Besides $\mathrm{CO}_{2}$, $\mathrm{H}_{2} \mathrm{~S}\left(2.7 \times 10^{-4}\right.$ to $\left.1.72 \times 10^{-1} \%\right), \mathrm{He}\left(5.91 \times 10^{-5}\right.$ to $\left.1.66 \times 10^{-2} \%\right), \mathrm{Ne}\left(6.39 \times 10^{-7}\right.$ to $\left.5.80 \times 10^{-3} \%\right)$, $\mathrm{H}_{2}\left(1 \times 10^{-5}\right.$ to $\left.2.3 \times 10^{-1} \%\right) \mathrm{CO}\left(6 \times 10^{-5}\right.$ to $\left.5 \times 10^{-4} \%\right), \mathrm{CH}_{4}\left(3.5 \times 10^{-2}\right.$ to $\left.1.69 \%\right), \mathrm{N}_{2}\left(1.5 \times 10^{-1}\right.$ to $74.5 \%)$, and $\mathrm{O}_{2}\left(2 \times 10^{-3}\right.$ to 18.99$)$ are present in the gas samples. The ternary diagram $\mathrm{CO}_{2} / 50-\mathrm{N}_{2}-\mathrm{O}_{2}$ (Figure 3) shows a progressive enrichment in $\mathrm{N}_{2}$ and $\mathrm{O}_{2}$ of the samples, indicating a variable amount of air.

The ${ }^{3} \mathrm{He} /{ }^{4} \mathrm{He}$ ratios range between 0.77 to $3.10 \mathrm{R}_{\mathrm{a}}$ and the ${ }^{4} \mathrm{He} /{ }^{20} \mathrm{Ne}$ ratios from 0.36 and 1700, which show that some of the collected gases are affected by air contamination (Table 3). The ${ }^{3} \mathrm{He} /{ }^{4} \mathrm{He}$ ratios after corrections for the air contamination $\left(\mathrm{R} / \mathrm{R}_{\mathrm{ac}}\right)$ are up to 3.25 . The $\delta^{13} \mathrm{C}_{\mathrm{CO} 2}$ ranges between $-1.40 \%$ and $-17.2 \%$ vs. V-PDB (Table 3).

\subsection{Noble gas ratios of fluid inclusions from Persani clinopyroxenes}

Helium content in the fluid inclusions in clinopyroxenes ranged between $4.06 \times 10^{-12}$ and $3.81 \times 10^{-12} \mathrm{~mol} / \mathrm{g}$, Ne content between $2 \times 10^{-15}$ and $2.74 \times 10^{-15} \mathrm{~mol} / \mathrm{g}$, so the He/ $\mathrm{Ne}$ ratios ranged between 1390 and 2030. The He isotopic signature in fluid inclusions was $5.95 \mathrm{Ra} \pm$ 0.01 (Table 4).

\section{Discussion}

\subsection{Crustal assimilation vs. mantle metasomatism}

Helium comes from three different sources (mantle, crust and air), which can be readily distinguished based on their characteristic isotopic ratios (Sano \& Wakita, 1985). Helium 
isotopes are useful tracers for detecting deep fluids and their possible origin (crust, mantle or atmosphere) (Ozima and Podosek 2002). It has been demonstrated that in the case of quiescent volcanoes, the active degassing of deep volatiles can occur for a long time after the last volcanic activity (Carapezza et al., 2007; Tassi et al., 2013; Caracausi et al., 2009 and 2015).

The last eruption in Ciomadul occurred 30 ka (Harangi et al., 2010; 2015b; Molnár et al., 2019), yet there is an intense $\mathrm{CO}_{2}$ degassing with a minimum flux of $8.7 \times 10^{3} \mathrm{t} \mathrm{yr}^{-1}$ (Kis et al., 2017), which is comparable to other dormant volcanic areas such as Panarea $\left(1.72 \times 10^{4} \mathrm{t}\right.$ $\left.\mathrm{yr}^{-1}\right)$ and Roccamonfina $\left(7.48 \times 10^{3} \mathrm{t} \mathrm{yr}^{-1}\right)$ from Italy or Jefferson $\left(7.92 \times 10^{3} \mathrm{t} \mathrm{yr}^{-1}\right)$ from the USA.

In addition, previous investigations (Althaus et al., 2000; Vaselli et al., 2002) highlighted the outgassing of mantle-derived volatiles at Ciomadul volcano. He isotopic ratios in the fluids collected in this study are up to $3.1 \mathrm{R}_{\mathrm{a}}$ similar to those obtained from previous studies (Figure 4, Table 3). These values are higher than those obtained from the surrounding areas such as in the Carpathian Foredeep and the Transylvanian Basin where He isotopic ratios are between 0.02 and $0.03 R_{\mathrm{a}}$ (Vaselli et al., 2002; Italiano et al., 2017; Baciu et al., 2017, Figure 4).

These latter values are typical of crustal fluids dominated by ${ }^{4} \mathrm{He}$ produced by decay of $\mathrm{U}$ and Th (e.g., Ozima and Podosek, 2002). The higher $\mathrm{R}_{\mathrm{a}}$ values measured at Ciomadul could imply a higher contribution of magmatic He. Nevertheless, the $3.1 \mathrm{R}_{\mathrm{a}}$ value is significantly lower than the MORB and SCLM value (Sano \& Marty, 1995) requiring addition of radiogenic ${ }^{4} \mathrm{He}$ that decreased the pristine isotopic signature.

The mantle xenoliths of the Perşani volcanic field (ca. $40 \mathrm{~km}$ from the Ciomadul area) could provide the $\mathrm{He}$ isotopic signature of the lithospheric mantle beneath the region. The $\mathrm{He}$ isotopic ratios in fluid inclusions of the Persani clinopyroxenes are 5.95 \pm 0.01 (Table 4) and these are lower than those of of previous measurements, from 6.5 to $7.3 \mathrm{R}_{\mathrm{a}}$, obtained by Althaus et al. (1998), but consistent with the values of the Subcontinental Lithospheric Mantle (SCLM, R/R $\mathrm{R}_{\mathrm{a}}=6.1 \pm 0.9 \mathrm{R}_{\mathrm{a}}$, Gautheron \& Moreira, 2002). The continental crust $\left(\mathrm{R} / \mathrm{R}_{\mathrm{a}}=0.02\right.$, Ozima and Podosek, 2002) and atmosphere $\left(\mathrm{R} / \mathrm{R}_{\mathrm{a}}=1\right)$ have distinct isotopic values and ${ }^{4} \mathrm{He} /{ }^{20} \mathrm{Ne}$ can be used to infer how mixing between the three possible endmembers can support the He isotopic signature of the fluids that outgass in the Ciomadul region (Figure 4). Most Ciomadul samples indicate a possible trend between air and a magmatic source, where the He ratio of the magmatic end-member $\left(3.1 R_{a}\right)$ is lower than that of the ECLM and the Perşani clinopyroxene. This is also supported by the trend line in the ${ }^{3} \mathrm{He}-\mathrm{CO}_{2}-{ }^{4} \mathrm{He}$ ternary diagram (Figure 5), where the Ciomadul samples are along a trend showing variable amounts of $\mathrm{CO}_{2}$ and $\mathrm{R} / \mathrm{R}_{\mathrm{ac}}$ values between 2 and 3 . This trend reflects the dominance of radiogenic $\mathrm{He}$ in the fluids outgassing from the Ciomadul volcano. We have now to assess the possible processes that can add the radiogenic He component to the mantle component.

Such a relatively low He isotope ratio of the magma source is not uncommon in volcanic arc settings (e.g., Hilton et al., 1992; Allard et al., 1997; Inguaggiato et al., 1998; Martelli et al., 2004) and can be due to several processes involving the addition of radiogenically-produced ${ }^{4} \mathrm{He}$, such as magma aging, crustal assimilation, mixing between mantle and crustal-derived fluids, among others (Torgersen et al., 1995; Kennedy et al., 2006). Unfortunately, there are no undifferentiated mantle-derived mafic rocks in the region of the Ciomadul volcano, so we cannot investigate the He isotope composition of the mantle directly below the volcano. In Ciomadul, only high-K dacitic volcanic products are found (Mason et al., 1996; Vinkler et al., 2007; Molnár et al., 2018; 2019), although occurrence of high-Mg minerals such as 
olivine and clinopyroxene in the dacites suggest involvement of primitive mafic magmas in the magma evolution of Ciomadul (Vinkler et al., 2007; Kiss et al., 2014).

Magma aging and crustal assimilation are two mechanisms that could account for the addition of the radiogenic He component to the mantle-derived melts. Both these processes have been invoked to explain low He isotopic ratios (< MORB and SCLM) in different volcanic regions, worldwide, such as Aeolian Island, Italy (Mandarano et al., 2015) and Iceland (Condomines et al., 1993). The magma-aging mechanism considers an addition of ${ }^{4} \mathrm{He}$ by radiogenic decay in the magma itself. In constrast, crustal assimilation furnishes ${ }^{4} \mathrm{He}$ by interaction between magma and the whole rock. First, we investigated the likelihood that the magma aging model can interpret the low He isotopic signature in the fluids that outgas at Ciomadul volcano.

The ${ }^{3} \mathrm{He} /{ }^{4} \mathrm{He}$ ratio of the fluid inclusions of the Persani clinoproxene (5.95Ra \pm 0.01$)$ can be assumed to represent the mantle end-member value beneath of the region. Thus, the primary magmas of Ciomadul could be also characterized by such isotope ratio. The Ciomadul dacites have $U$ and Th concentrations of 3 and 15 ppm respectively (Vinkler et al., 2007; Molnár et al., 2018; 2019). Using these data, the magma-aging model calculation yield ${ }^{3} \mathrm{He} /{ }^{4} \mathrm{He}$ ratio around $4.65 \mathrm{R}_{\mathrm{a}}$ after $30 \mathrm{kyr}$ (Figure 6). Thus, this process alone cannot be responsible for the low $\mathrm{He}$ (ca. 3.1 $\mathrm{R}_{\mathrm{a}}$ ) isotopic signature of the Ciomadul fluids. Furthermore, if we assume the $\mathrm{U}(1.5 \mathrm{ppm})$ and Th (5.5 ppm) contents of the Persani basalts (Harangi et al., 2013), the magma-aging model is still not a viable process to provide the required ${ }^{4} \mathrm{He}$ addition and generate the low ${ }^{3} \mathrm{He} /{ }^{4} \mathrm{He}$ for Ciomadul gases.

The relatively low He isotopic ratio can also be explained by high-level crustal assimilation (e.g., van Soest et al., 2002), which has to also be evaluated. Assuming the U and Th amount of the typical upper crust, 2.7 and 10.5 ppm, respectively (Rudnick and Gao, 2014) and an age of $5 \mathrm{Ma}, 3 \%$ of crustal assimilation could be sufficient to achieve the observed low He isotopic ratios. The $\mathrm{Sr}-\mathrm{Nd}-\mathrm{O}$ isotope compositions of the erupted magmas sensitively reflect such a process. Mason et al. (1996) published isotopic data for three samples of the Ciomadul volcanic system. They have distinct isotopic features compared to the calc-alkaline volcanic suite of the Calimani-Gurghiu-Harghita chain. Although the Sr-Nd isotopic data could suggest an AFC process with 10-35\% assimilation of flysch sediment, such a high crustal contamination is not feasible, based on the fairly low $\delta^{18} \mathrm{O}$ values (6.3-7.1 per mil) of the phenocrysts from the dacites (Mason et al., 1996). Instead, they suggested that these isotopic characteristics could also be explained by source contamination from subduction-related fluids. In fact, the bulk-rock composition of the Ciomadul dacites has unique characteristics with high $\mathrm{Sr}$, Ba (both showing typically $>1000 \mathrm{ppm}$ ) and high $\mathrm{K}$ compositions and low concentrations of heavy rare-earth elements (Seghedi et al., 1987; Vinkler et al., 2007; Molnár et al., 2018; 2019). Furthermore, the high-Mg pargasitic amphiboles thought to have derived from the less differentiated magmas have also relatively high Ba content (Kiss et al., 2014). Thus, these peculiar compositional characters can be due to the nature of the magma source rather than magma differentiation processes. The elevated K, $\mathrm{Sr}$ and $\mathrm{Ba}$ contents of the assumed mantle source of the Ciomadul primary magmas can be due to metasomatism and this is in contrast what the peridotite xenoliths from the Persani volcanic field show (Vaselli et al., 1995). In fact, the He signature of the outgassed volatiles at Ciomadul resembles the values in fluids from other subduction-related volcanic systems (i.e., Italy, Greece, Indonesia; Hilton et al., 1992; Martelli et al., 2004; Shimizu et al., 2005), where the mantle source regions seem to be contaminated by crustal material which added radiogenic ${ }^{4} \mathrm{He}$ and decreased the pristine He isotopic signature (Hilton et al., 2002).

Such a small-scale spatial heterogenity of the lithospheric mantle beneath this area can be explained by the closer location of Ciomadul to the collision front, where subduction is 
expected to have occurred during the Miocene up to around $11 \mathrm{Ma}$ (Royden et al., 1982; Cloetingh et al. 2004; Matenco et al., 2007; Seghedi et al., 2011). Such a scenario is not unique, Martelli et al. (2004) suggested that the relatively low He isotopic ratio in the volcanic rocks of Central Italy can be explained by magma source features (i.e., contribution of radiogenic $\mathrm{He}$ from metasomatic, subduction-related fluids and ingrowth of ${ }^{4} \mathrm{He}$ in the lithospheric mantle). We note that the ${ }^{87} \mathrm{Sr} /{ }^{86} \mathrm{Sr}$ isotopic ratio of the Ciomadul dacites and the highest ${ }^{3} \mathrm{He} /{ }^{4} \mathrm{He}$ isotopic values of the emitted gases plot into the same trend (Figure. 5 in Martelli et al., 2004) what the Central Italian volcanic areas form.

In summary, considering the petrology of the Ciomadul volcanic products, the relatively low He isotope magmatic end-member of the Ciomadul gases can be interpreted as due to magma-source characteristics, where the radiogenic He was added via subduction-related fluids and increased radioactive ingrowth following the metasomatism. However, a mixing between mantle-derived fluids with and SCLM He isotopic signature and ${ }^{4} \mathrm{He}$-rich crustal fluids coming from shallow crustal layers should still be further explored as a possible process responsible of the low He isotopic ratios in the Ciomadul fluids. This likelihood will be discussed in the next section.

\subsection{Sources and origin of carbon-dioxide}

The carbon isotopic composition of $\mathrm{CO}_{2}\left(\delta^{13} \mathrm{C}_{\mathrm{CO} 2}\right)$ from the studied fluids range between $1.40 \%$ and $-4.61 \%$ vs. VPDB, consistent with previous measurements in the area (-2.77 to 4.70\%; Vaselli et al., 2002; Frunzeti, 2013; Sarbu et al., 2018). In the Pannonian Basin (central Europe), the carbon isotopic composition of $\mathrm{CO}_{2}$ gases shows values in a narrow range between -3 to $-7 \%$ with an average value of $-5 \%$ V-PDB based on hundreds of measurements (Cornides, 1993; Sherwood-Lollar et al., 1997; Palcsu et al., 2014; Bräuer et al., 2016). These values are consistent with a mantle origin. In contrast, crustal-derived $\mathrm{CO}_{2}$ is characterized by a $\delta^{13} \mathrm{C}$ of about $-25 \%$ in case of biogenic sedimentary source and around 0 $\%$ considering thermo-metamorphism of limestone (Sano\&Marty, 1995 and references therein). The Ciomadul gases overlap the range of mantle composition, even if some samples have more positive values that cannot be explained by the addition of a crustal biogenic component (table 3 and Figures 7 and 8). To constrain the origin of $\mathrm{CO}_{2}$ in the fluids emitted by the Ciomadul volcano, we used the relationship between the elemental ratio $\mathrm{CO}_{2} /^{3} \mathrm{He}$ and the isotopic signature $\delta^{13} \mathrm{C}_{\mathrm{CO} 2}$ (Sano and Marty, 1995; Figure 7). The $\mathrm{CO}_{2} /{ }^{3} \mathrm{He}$ ratios of the Ciomadul gases are higher than $2 \times 10^{9}$, the expected mantle ratio (Marty and Jambon, 1987) and which suggests an addition of a crustal component. It is interesting that these ratios fall into the same trend as shown by volcanic and fumarolic gases measured at volcanic arcs, worldwide (Mason et al., 2017; Figure 8a and b). Almost all the Ciomadul samples fall close the mixing line between a mantle component and a limestone end-member suggesting that mixing of the two sources could be the main process that controls the $\mathrm{CO}_{2-}{ }^{3} \mathrm{He}$ systematics in these fluids. In contrast, $\mathrm{CO}_{2}$ fluids in the Transylvanian Basin, (Baciu et al., 2007, 2017) west of the volcano have distinct character and fall closer to the mantle - organic sediment mixing line. Rayleigh-type fractionation due to gas exsolution from water is not a plausible process to produce the carbon isotopic signature and the $\mathrm{CO}_{2}{ }^{3} \mathrm{He}$ of the studied fluids (Figure 7) (Holland\&Gilfilland, 2013; Roulleau et al., 2015). However, the ${ }^{13} \mathrm{C}_{\mathrm{CO} 2}$ values of most of the samples fall in the narrow range of -2 and $-5 \%$, which is a typical signature for mantle-derived carbon. We obtain the same trend in the $\mathrm{He}$ isotopic ratios $\left(\mathrm{R} / \mathrm{R}_{\mathrm{a}}\right)$ vs. ${ }^{13} \mathrm{C}_{\mathrm{CO} 2}(\mathrm{~V}-\mathrm{PDB})$ plot (Figure 8a and $\left.\mathbf{b}\right)$, where the Ciomadul samples clearly approach the mantle end-member and overlap the isotopic values of many other volcanic systems related to subduction areas. Remarkably the Ciomadul samples show 
similarities in He-C isotopic composition with active and dormant volcanic regions (e.g., Italy and Indonesia).

The involvement of carbonatic component can be explained by mixing with fluids derived from thermometamorphic decomposition of carbonates in the flysch sedimentary pile or by mantle source contamination via subducted carbonatic material The mantle source of the Ciomadul magmas is considered to be a metasomatic lithospheric mantle based on the compositional features of the dacitic rocks. The relatively low He isotopic ratio can due to these source characteristics, whereas metasomatism was the result of slab-derived fluids during the Miocene subduction along the Eastern Carpathians followed by ingrowth of radiogenic He by radioactive decay. The $\mathrm{Sr}-\mathrm{Nd}-\mathrm{O}$ isotope data of the volcanic rocks do not support significant upper-level crustal contamination, but rather crustal component addition to the source region via slab-derived fluid metasomatism (Mason et al., 1996). The combination of $\mathrm{He}$ and $\mathrm{C}$ isotopic data suggests that this crustal component consisted of decomposed subducted carbonate material as suggested also for the volcanic rocks in Italy, although addition of fluids from carbonate decomposition at shallow crustal level cannot be unambiguously excluded.

\subsection{Relationship with the deep magmatic system}

Dormant volcanoes pose a particular hazard to society since there is much less awareness about a possible eruption event. However, the scientific community is giving increased attention to these volcanoes and the surrounding areas that are generally characterized by intense gas emissions (Burton et al., 2013 and references therein). Recent investigations highlighted the presence of an active plumbing system even below volcanoes which last erupted >10 kyr (e.g., Colli Albani, Italy; Trasatti et al., 2018; Uturuncu, Bolivia; Sparks et al., 2008; Comeau et al., 2015; Tatun, Taiwan; Konstantinou et al., 2007; Lin \& Pu, 2016). Harangi et al. (2015a) suggested the term PAMS volcano, i.e. volcano with Potentially Active Magma Storage for these long-dormant volcanoes, which have clear implication for a subvolcanic melt-bearing magma plumbing system. Ciomadul belongs to this category, since there are a number of observations suggesting that a melt-bearing magma body could still exist beneath it (Popa et al., 2012; Szakács and Seghedi, 2013; Harangi et al., 2015a). The isotopic composition of the emitted gases coupled to the high localized heat flow in the area of the Ciomadul vocano gives additional support to this interpretation.

This involves the similarities in the isotope composition of $\mathrm{CO}_{2}$, and $\mathrm{He}$ of the gases emitted at the Ciomadul with those found in other active and dormant volcanic arc systems worldwide and their proposed high magmatic component. Furthermore, the Ciomadul volcanic system is characterized by relatively high $\mathrm{CO}_{2}$ gas fluxes (Kis et al., 2017). This is consistent with the presence of a still-degassing magma below the Ciomadul system as inferred by geophysical investigations that recognized a low-resistivity and low-velocity anomaly in the crust, below the volcano (Popa et al., 2012; Harangi et al., 2015a) as well as petrologic observations suggesting the involvement of a mafic magma in the petrogenesis of the erupted dacite (Kiss et al., 2014). The measurements of U-Th and U-Pb spot ages on zircons suggest a long-standing magma storage that could go back as far as about $350 \mathrm{ka}$ (Harangi et al. 2015b; Lukács et al., 2018). Molnár et al. (2018; 2019) presented a detailed eruption chronology for the Ciomadul lava dome field involving the Ciomadul volcanic complex and emphasized that volcanic activity could be renewed even after long ( $>100 \mathrm{kyr})$ repose times. Several 10's kyr quiescence periods between the active phases have also been pointed out also during the evolution of the Ciomadul volcanic complex (Harangi et al., 2015b; Molnár et al., 2019). However, the zircon U-Th and U-Pb ages suggest that 
crystallization was on-going also during the long quiescence periods, i.e. there was an active magma storage beneath the apparently inactive volcano This suggests a long-standing felsic upper-crustal crystal mush system underlain by a mafic hot zone in the lower crust, as has already been suggested by petrologic interpretations (Kiss et al. 2014). The diverse amphibole compositions in the dacites are consistent with a polybaric magma evolution, i.e. with transcrustal magma storage (Cashman et al., 2017; Sparks \& Cashman, 2017) comprising ephemeral melt-dominated bodies, i.e. magma chambers at various depths. In addition, fluid-gas accumulation zones can also have developed within this magma storage (Christopher et al., 2015; Sparks \& Cashman, 2017). Thus, a possible source of the $\mathrm{CO}_{2}$ gases could be these fluid entrapment zones within the crystal mush during quiescent period. However, gas emission is more common around the Ciomadul volcanic complex and significantly lower within the volcano itself (Kis et al. 2017). Allard et al. (1991) and Edmonds (2008) pointed out that stronger degassing around the volcanic edifice is not uncommon in volcanic regions. An alternative source of the $\mathrm{CO}_{2}$ gases could be mafic magma residing at deeper level, possibly at the lower crust. Indeed, the occurrence of highMg minerals, such as olivine, clinopyroxene and orthopyroxene in the dacites (Vinkler et al., 2007; Kiss et al., 2014) suggests that mafic magma also played an important role in the magma evolution. Harangi et al. (2015a) detected a lower crustal low resistivity anomaly, which might represent the mafic magma accumulation. Thus, we propose that most of the $\mathrm{CO}_{2}$ gases could come directly from the presumed mafic-magma accumulation zone at the lower crust through fractures (Kis et al., 2017), whereas only limited amount of gases are derived from the mushy magma storage.

Vaselli et al. (2002) already suggested that the emitted gases in Southern Harghita could have a magmatic component. Based on our new measurements, we support this interpretation, particularly in the area of Ciomadul volcano. Assuming that a deep-seated mafic magma body can be the main source of the $\mathrm{CO}_{2}$ gases and considering that it is characterized by relatively low ${ }^{3} \mathrm{He} /{ }^{4} \mathrm{He}$ isotope signature $\left(3.1 \mathrm{R}_{\mathrm{a}}\right)$ inherited by the mantle source region, we can use this value to calculate the relative magmatic component of the emitted gases (Sano \& Wakita, 1985). If no interaction with crustal fluids occurred, the magmatic component in the gases could exceed even the $80 \%$. Remarkably, we obtained such high values for the areas having a larger diffusive $\mathrm{CO} 2$ flux. This high magmatic He content of the gases is not unique and resembles what Trasatti et al. (2018) proposed for Colli Albani volcanic complex, another long-dormant volcanic field, where they assumed more than $80 \%$ mantle-derived component in the emitted $\mathrm{CO}_{2}$ gases. However, the magmatic component can be lower, if interaction between the ascending gases with crustal gases occurred at shallow crustal depth, a possibility what we cannot test at this stage, but requires further studies.

\section{Conclusions}

We investigated 31 gas emissions at the Ciomadul volcano, a long-dormant PAMS volcano in eastern-central Europe, to constrain the origin of the emitted volatiles and the possible processes that modify their chemistry during the transfer of these fluids towards the surface. The carbon and helium isotopic compositions provide evidence for a significant magmatic component. Our study shows a clear magmatic component in the emitted fluids and the highest values correspond to the area characterized by the highest $\mathrm{CO}_{2}$ flux from soil, so the high fluxes can be associated with the highest contribution of volatiles derived from a magma body.

The relatively large $\mathrm{CO}_{2}$ gas emission and significant magmatic component of the gases are consistent with geophysical and petrologic models (Popa et al., 2012; Harangi et al., 2015a, 2015b), that a degassing magmatic intrusion could still exist beneath Ciomadul. A long- 
standing silicic crystal mush body should be developed in the shallow crust, while a mafic magma accumulation zone is inferred at the lower crustal level. The magmatic gases could be derived either from a deep mafic magma and/or from the volatile accumulation zones developed in the shallow crustal felsic-crystal mush body. Petrology and geochemistry of the erupted dacitic magma imply that upper crustal contamination played no or subordinate role and the primary magmas could have derived from a mantle source contaminated by subduction-related fluids that is consistent with the He and $\mathrm{C}$ isotope composition of the gases emitted at Ciomadul volcano. Thus, a magma source with relatively low He isotope value $\left(3.10 \mathrm{R}_{\mathrm{a}}\right)$, similar what was proposed for volcanic systems in central Italy and Greece seems to be viable beneath Ciomadul. This differs from the SCLM value detected at the nearby Persani volcanic field (Althaus et al. 1998; this study) and also in the Pannonian basin (Cornides, 1993; Palcsu et al., 2014; Bräuer et al., 2016) and requires a spatially-variable modified lithospheric mantle even a small scale. The isotopic composition $\left(\mathrm{He}\right.$ and $\left.\mathrm{CO}_{2}\right)$ of the emitted volatiles implies interaction of crustal gases to varying degrees, although some of them could reach the surface without major modification.

\section{Acknowledgements}

Information regarding the support of the conclusions of this work can be found in the tables and within the text.

This research on the Ciomadul volcano was initiated during the MTA Postdoctoral Fellowship of Boglárka-Mercedesz Kis and belongs to the scientific project supported by the OTKA (Hungarian National Research Fund) No. K116528. The research was also supported by the European Union and the State of Hungary, co-financed by the European Regional Development Fund in the project of GINOP-2.3.2-15-2016-00009 'ICER' and we acknowledge the support of the Deep Energy Community of the Deep Carbon Observatory. Thorough reviews and constructive comments provided by Emilie Roulleau and Daniele Pinti helped considerably to clarify the ideas described in the paper. We thank Timothy Jull who provided a final polishing of the English of the manuscript.

\section{References}

Aguilera, F., Tassi, F., Darrah, T., Moune, S. \& Vaselli, O. (2012).Geochemical model od magmatic-hydrothermal system at the Lastarria volcano, Northern Chile. Bulletin of Volcanology, 74, 119-134. doi:1m.1007/s00445-011-0489-5

Agusto M., Tassi F., Caselli A.T., Vaselli O., Rouwet D., Capaccioni B., Caliro S., Chiodini G. \& Darrah T. (2013).Gas geochemistry of the magmatic-hydrothermal fluid reservoir in the Copahue-Cavihue Volcanic Complex (Argentina). Journal of Volcanology and Geothermal Research, 257, 44-56. 10.1016/j.jvolgeores.2013.03.003

Allard, P. (1983). The origin of hydrogen, carbon, suplhur, nitrogen and rare gases in volcanic exhalations: evidence from isotope geochemisty. In H. Tazieff, J.C. Sabroux, (Eds.) Forecasting Volcanic Events, (pp.337-386), Amsterdam, Elsevier.

Allard, P., Carbonelle, J., Dajlevic, D., Le Bronec, J., Morel, P., Robe, M.C., Maurenas, J.M., Faivre-Pierret, R., Martin, D., Sabroux, J.C., Zettwoon, P. (1991). Eruptive and diffuse emissions of $\mathrm{CO}_{2}$ from Mount Etna,Nature, 351, 387-391, doi:10.1038/351387a0 
Allard, P., Jean-Baptiste, P., D’Alessandro, W., Parello, F., Parisi, B. \& Flehoc, C. (1997). Mantle-derived helium and carbon in groundwaters and gases ofMount Etna, Italy.Earth and Planetary Science Letters, 148, 501-516

Althaust, A., Niedermann, S. \& Erzinger, J.(1998). Noble gas in ultramafic mantle xenoliths in the Persani Mountains, Transylvanian Basin, Romania.Mineralogical Magazine, 62A, 4344

Althaus, T., Niedermann, S., Erzinger, J. 2000. Noble gas studies of fluids and gas exhalations in the East Carpathians, Romania. Chemie der Erde. 60:189-207.

Aiuppa, A., Moretti, R., Federico, C., Giudice, G., Gurrieri, S., Liuzzo, M., Papale, P. Shinohara, H. \& Valenza, M. (2007). Forecasting Etna eruptions by real-time observation of volcanic gas composition. Geology, 35(12), 1115-1118, doi:10.1130/G24149A.1

Baciu, C., Caracausi, A., Etiope, G., Italiano, F. (2007). Mud volcanoes and methane seeps in Romania: main features and flux, Annals of Geophysics, 50, 4, doi: 10.4401/ag-4435

Baciu, C., Ionescu, A., Etiope, G., (2017). Hydrocarbon seeps in Romania: Gas origin and release to the atmosphere, Marine and Petroleum Geology, 89, 1, 130-143, doi: 10.1016/j.marpetgeo.2017.06.015

Băncilă I.(1958).Geology of the Eastern Carpathians.Bucharest, Editura Stiintifica

Barry, P.H., Hilton, D.R., Füri, E., Halldórsson, S.A. \& Grönvold, K. (2014). Carbon isotope and abundance systematics of Icelandic geothermal gases, fluids and subglatial basalts with implications from mantle plume-related $\mathrm{CO}_{2}$ fluxes.Geochimica et Cosmochimica Acta, 134, 74-99. doi:10.1016/j.gca.2014.02.038

Barry, P.H., Hilton, D.R., Fischer, T.P., de Moor, J.M., Mangasini, F.\& Ramirez, C.(2013). Helium and carbon isotope systematic of cold "mazucu" $\mathrm{CO}_{2}$ vents and hydrothermal gases and fluid from Rungwe Volcanic Province, southern Tanzania.Chemical Geology, 339, 141156.doi: 10.1016/j.chemgeo.2012.07.003

Berszán J., Jánosi Cs., Jánosi K., Kristály F., Péter É., Szakáll S.\& Ütő G.(2009).The mineral waters of Szeklerland.Miercurea Ciuc, Tipographic (In Hungarian)

Bräuer, K., Geissler, W.H., Kämpf, H., Niedermann, S., Rman, N. (2016). Helium and carbon isotope signatures of gas exhalations in the westernmost part of the Pannonian Basin (SE Austria/NE Slovenia): Evidence for active litospheric mantle degassing. Chemical Geology, 422, 60-70, doi: 10.1016/j.chemgeo.2015.12.016

Bräuer, K., Kämpf, H., Niedermann, S., Strauch, G. \& Tesar J.(2008). Natural laboratory NW Bohemia: Comprehensive fluid studies between 1992 and 2005 used to trace geodynamic processes.Geochemistry, Geophysics, Geosystems, 9(4), 1-30. doi: 10.1029/2007GC001921

Bräuer, K., Kämpf, H., Niedermann, S. \& Strauch, G. (2018). Monitoring of helium and carbon isotopes in the western Eger Rift area (Czech Republic): Relationships with the 2014 seismic activity and indications for recent (2000-2016) magmatic unrest. Chemical Geology, 482, 131-145. 10.1016/j.chemgeo.2018.02.017 
Caliro, S., Viveiros F., Chiodini, G. \& Ferreira, T. (2015).Gas geochemistry of hydrothermal fluids of the S.Miguel and Terceira Islands, Azores. Geochimica et Cosmochimica Acta, 168, 43-57. doi: 10.1016/j.gca.2015.07.009

Capaccioni, B., Aguilera, F., Tassi, F., Darrah, T., Poreda, R. \& Vaselli, O.

(2011).Geochemical and isotopic evidences od magmatic inputs in the hydrothermal reseryoirs feeding the fumarolic discharges on Tacora volcano (Northern Chile). Journal of Volcanology and Geothermal Research, 208, 77-85. doi:10.1016/j.jvolgeores. 2011.09.015

Capasso, G., Carapezza, M., Federico, C., Inguaggiato, S. \& Rizzo, A.(2005b).Geochemical monitoring of the helium isotopic composition of fumarole gases and thermal waters. Bulletin of Volcanology, 68, 118-134. doi:10.1007/s00445-005-0427-5

Capasso, G., Favara, R., Grassa, F., Inguaggiato, S. \& Longo, M.(2005a). On-line technique for preparation and measuring stable carbon isotope of total dissolved inorganic carbon in water samples ( $\left.\delta^{13} \mathrm{C}_{\mathrm{TDIC}}\right)$. Annals of Geophysics, 48(1), 159-166. doi:10.1.1.1002.372

Caracausi A., Nuccio P.M., Favara R., Nicolosi M.\& Paternoster M. (2009).Gas hazard assessment at the Monticchio crater lakes of Mt. Vulture, a volcano in southern Italy. Terra Nova, 21,8387,doi:10.11111/1365-3121.200800858

Caracausi, A., Favara, R., Giammanco, S., Italiano, F., Paonita, A., Pecoraino,G.\& RizzoA.(2003).Mount Etna: Geochemical signals of magma ascentand unusually extensive plumbing system. Geophysical Research Letters, 30(2),1057, doi:10.1029/2002GL015463

Caracausi A., Martelli, M., Nuccio, P.M., Paternoster, M.\& Stuart, F.M. (2013).Active degassing of mantle-derived fluid: A geochemical study along the Vulture line, southern Apenninnes (Italy). Journal of Volcanology and Geothermal Research, 253, 65-74, 10.1016/j.jvolgeores.2012.12.005

Caracausi, A., Paternoster M.\& Nuccio P.M. (2015). Mantle $\mathrm{CO}_{2}$ degassing at Mt. Vulture volcano (Italy): Relathionhip between $\mathrm{CO}_{2}$ outgassing of volcanoes and the time of their last eruption. Earth and Planetary Science Letters, 411,268-280, doi:10.1016/j.epsl.2014.11.049

Carapezza, M. L., Badalamenti, B., Cavarra, L.\& Scalzo, A. (2003).Gas hazard assessment in a densely inhabited area of Colli Albani Volcano (Cava dei Selci, Roma).Journal of Volcanology and Geothermal Research, 123, 81-94, doi: 10.1016/S0377-0273(03)00029-5

Carapezza, M.L., Barbieri, F., Ranaldi, M., Ricci, T., Tarchini, L., Barrancos, J., Fischer, C., Granieri, D., Lucchetti, C., Melian, G., Perez, N., Tuccimei, P., Vogel, A. \& Weber, K. (2012).Hazardous gas emissions from the flanks of the quiescent Colli Albani volcano (Rome, Italy).Applied Geochemistry, 27, 1767-1782, doi: 10.1016/j.apgeochem.2012.02.012

Carapezza, M.L.\& Tarchini, L. (2007).Accidental gas emission from shallow pressurized aquifers at Alban Hills volcano (Rome, Italy): Geochemical evidence of magmatic degassing? Journal of Volcanology and Geothermal Research, 165, 5-16. doi:10.1016/j.jvolgeores.2007.04.008 
Cardellini, C., Chiodini, G., Frondini, F., Avino, R., Bagnato, E., Caliro, S., Lelli, S. \& Rosiello, A. (2017). Monitoring diffuse volcanic degassing during volcanic inrest: the case of Campi Flegrei (Italy).Scientific Reports, 7, 6757,doi:10.1038/s41598-017-06941-2

Cashman, K.V., Sparks, S., Blundy, J.D. (2017). Vertically extensive and unstable magmatic systems: An unified view of igneous processes.Science, 355, 6331, doi: 10.1126/eaay3055

Ciotoli, G., Etiope, G., Florindo, F., Marra, F., Ruggiero, L. \& Sauer, P.E. (2013).Sudden deep gas eruption nearby Rome's airport of Fiumicino.Geophysical Research Letters, 40, 15, doi:10.1002/2013GL058132

Christopher, T.E., Blundy, J., Cashman, K., Cole, P., Edmonds, M., Smith, P.J., Sparks, R.S.J., Stinton, A. (2015). Crustal-scale degassing due to magma system destabilization and magma-gas decoupling at Soufriere Hills Volcano, Montserrat, Geohemistry, Geophysics, Geosystems, 16, 9, 2797-2811, doi: 10.1002/2015GC005791

Christopher, T., Edmonds, M., Humphreys, M.C.S. \& Herd, R.A. (2010). Volcanic gas emissions from Soufriere Hills Volcano, Montserrat 1995-2009, with implications for mafic magma supply and degassing. Geophysical Research Letters, 37, L00E04, doi: 10.1029/2009GL041325

Comeau, M.J., Unsworth, M.J., Ticona, F.\& Sunagua, M. (2015). Magnetotelluric images of magma distribution beneath Volcano Uturuncu, Bolivia: Implications for magma dynamics.Geology, 43(3), doi:10.1130/G36258.1

Comeau, J.M., Unsworth, M.J.\& Cordell, D.(2016). New constraints on the magma distribution and composition beneath Volcan Uturuncu and the southern Bolivian Altiplano from magnetotelluric data, Geosphere, 12(5), 1391-1421, doi: 10.1130/GES01277.1

Condomines, M., Gronvold K., Hooker P.J., Muehlenbachs, O’Nions R.K., Oskarsson N. \&Oxburgh E.R., (1983). Helium, oxygen, strontium and neodymium isotopic relationships in Iceland volcanics. Earth Planet. Sci. Lett., 66, 125-136.

Cornides I. (1993). Magmatic carbon dioxide at the crust's surface in the Carpathian Basin, Geochemical Journal, 27, 241-249, 10.2343/geochemj.27.241

Correale, A., Martelli,M., Paonita, A., Rizzo,A., Brusca, L.\& Scribano, V.(2012).New evidence of mantle heterogeneity beneath the Hyblean Plateau (southeast Sicily, Italy) as inferred from noble gases and geochemistry of ultramafic xenoliths. Lithos, 132-133, 70-81, 10.1016/j.lithos.2011.11.007

Csontos, L., Nagymarosy, A., Horváth, D.\& Kovác, M.(1992). Tertiary evolution of the intra Carpathian area: a model. Tectonophysics, 208, 221-241

Cloetingh, S.A.P.L., Burov, E., Matenco, L., Toussaint, G., Bertotti, G., Andriessen, P.A.M., Wortel, M.J.R. \& Spakman, W. (2004). Thermo-mechanical controls on the mode of continental collision in the SE Carpathians (Romania). Earth and Planetary Science Letters. 218 (1-2): 57-76. doi: 10.1016/S0012-821X(03)00645-9 
de Leeuw, G., Hilton, D., Fischer, T.P. \& Walker, J. (2007). The $\mathrm{He}-\mathrm{CO}_{2}$ isotope and relative abundance characteristics of geothermal fluids in El Salvador and Honduras: new constraints on volatile mass balance of the Central American Volcanic Arc. Earth and Planetary Science Letters, 258, 132-146, doi: 10.1016/j.epsl.2007.03.028

Demetrescu, C. \& Andreescu, M. (1994). On the thermal regime of some tectonic units in a continental collision environment in Romania. Tectonophysics, 230(3-4), 265-276, 10.1016/0040-1951(94)90140-6

Downes, H., Seghedi, I., Szakács, A., Dobosi, G., James, D.E., Vaselli, O., Rigby, I.J., Ingram,G.A., Rex, D.\& Pécskay, Z.(1995). Petrology and geochemistry of late Tertiary/Quaternarymafic alkaline volcanism in Romania. Lithos 35(1-2), 65-81, 10.1016/0024-4937(95)91152-Y

Edmonds, M.(2008). New geochemical insights into volcanic degassing, Phil. Trans.R.Soc.A, 366, 4559-4579, doi:10.1098/stra.2008.0185

Falus Gy., Tommasi, A., Ingrin, J. \& Szabó Cs. (2008). Deformation and seismic anisotropy of the lithospheric mantle in the southeastern Carpathians inferred from the study of mantle xenoliths. Earth and Planetary Science Letters, 272, 50-64, doi:10.1016/j.epsl.2008.04.035

Farrar, C.D., Sorey,M.L.,Evans, W.C., Howle,J.F., Kerr,B.D., Kennedy,B.M., King,C.Y.\&Southon, J.R.(1995).Forest Killing diffuse $\mathrm{CO}_{2}$ emission at Mammoth Mountain as a sign of magmatic unrest.Nature, 376, 675-677, doi: 10.1038/376675a0

Favara, R., Giammanco, S., Inguaggiato, S. \& Pecoraino, G. (2001).Preliminary estimate of $\mathrm{CO}_{2}$ output from Pantelleria Island volcano (Sicily, Italy): evidence for active mantle degassing. Applied Geochemistry, 16, 883-894,

Fischer, T., Horalek, J, Hrubcova, P., Vavrycuk, V., Bräuer, K. \& Kämpf, H.(2014). Intracontinental earthquake swarms in West-Bohemia and Vogtland: A review.Tectonophysics, 611, 1-27, doi: 10,1016/j.tecto.2013.11.001

Fischer, T.P., Giggenbach, W.F., Sano, Y.\& Williams, S.N. (1998). Fluxes and sources of volatiles discharged from Kudryavy, a subduction zone volcano, Kurile Islands.Earth and Planetary Science Letters, 160, 81-96, doi: 10.1016/S0012-821X(98)00086-7

Fischer, T.P. 2008. Fluxes of volatiles $\left(\mathrm{H}_{2} \mathrm{O}, \mathrm{CO}_{2}, \mathrm{~N}_{2}, \mathrm{Cl}, \mathrm{F}\right)$ from arc volcanoes. Geochemical Journal, 42 (1), 21-38, 10.2343/geochemj.42.21

Frunzeti, N. (2013).Geogenic emissions of greenhouse gases in the Southern part of the Eastern Carpathians, (Doctoral dissertation), Retrieved from Faculty of Environmental Science and Engineering. Cluj-Napoca. Babes-Bolyai University (In Romanian)

Gautheron, C. \&Moreira, M. (2002). Helium signature of the subcontinental lithospheric mantle, Earth and Planetary Science Letters, 199, 39-47, 10.1016/S0012-821X(02)00563-0 Grasu, C., Catana, C.\& Bobos, I. (1996).Petrology of the flysch formations in the inner Carpathians.Bucharest, Editura Tehnica 
Harangi Sz., Molnár M., Vinkler A.P., Kiss B., Jull A.J.T.\& Leonard A.E. (2010).

Radiocarbon dating of the last volcanic eruptions of Ciomadul volcano, Southeast

Carpathians, eastern-central Europe.Radiocarbon, 52(3), 1498-1507,

$10.1017 / \mathrm{S} 0033822200046580$

Harangi, S., Sági, T., Seghedi, I. \& Ntaflos, T.(2013). Origin of basaltic magmas of Perşani volcanic field, Romania: a combined whole rock and mineral scale investigation. Lithos 180 181,43-57. doi:10.1016/j.lithos.2013.08.025

Harangi Sz., Novák A., Kiss B., Seghedi I., Lukács R., Szarka L., Wesztergom V., Metwaly M.\& Gribovszki K. (2015a). Combined magnetotelluric and petrologic constrains for the nature of the magma storage system beneath the Late Pleistocene Ciomadul volcano (SE Carpathians).Journal of Volcanology and Geothermal Research, 290, 82-96, 10.1016/j.jvolgeores.2014.12.006

Harangi, Sz., Lukács, R., Schmitt, A.K., Dunkl, I., Molnár, K., Kiss, B., Seghedi, I., Novothny, A., Molnár M. (2015b). Constraints on the timing of Quaternary volcanism and duration of magma residence at Ciomadul volcano, east-central Europe, from combined U$\mathrm{Th} / \mathrm{He}$ and U-Th zircon geochronology. Journal of Volcanology and Geothermal Research, 301, 66-80, doi: 10.1016/j.jvolgeores.2015.05.002

Hilton, D.R., Hoogewerff, J.A., Van Bergen, M.J. \& Hammerschmidt, K. (1992). Mapping magma sources in the east Sunda-Banda arcs, Indonesia: constraints from helium isotopes, Geochimica et Cosmochimica Acta, 56, 851-859

Hilton, D. (1996). The helium and carbon isotope systematics of a continental geothermal system: results from monitoring studies at Long Valley caldera (California, U.S.A.).

Chemical Geology, 127, 269-295. doi: 10.1016/0009-2541(95)00134-4

Hilton, D.R., Fischer, T.P., Marty, B.(2002). Noble gases and volatile recycling at subduction zones. Rev. in Mineralogy and Geochemistry, 47, 1, 319-370, doi:10.2138/rmg.2002.47.9

Holland G. \& Gilfillan S., (2013). Application of the noble gases to the variability of $\mathrm{CO}_{2}$ storage. In: The noble gases as geochemical tracers, Pete Burnad Editor,177-223, Springer

Horváth, F., Bada, G., Windhoffer, G., Csontos, L., Dombradi, E., Dövényi, P., Fodor, L., Grenerczy, Gy., Síkhegyi, F., Szafián, P., Székely, B., Timár G., Tóth T., (2006). The geodynamic atlas of the Pannonian Basin: Euro-conform maps and explanations, Magyar Geofizika, 47, 4, 133-137 (In Hungarian).

Ianovici, V. and Rădulescu, D. (1968). Geological map 1:200000 L-35-XIV, $20^{\text {th }}$ SheetOdorhei. Geological Institute of Romania, Bucharest (In Romanian)

Ismail-Zadeh, A., Matenco, L., Radulian M., Cloetingh, S.\& Panza, S. (2012). Geodynamics and intermediate-depth seismicity in Vrancea (the south-eastern Carpathians): Current stateof-the art. Tectonophysics, 530, 50-79, doi: 10.1016/j.tecto.2012.01.016 
Italiano, F., Kis, B.M., Baciu, C., Ionescu, A., Harangi, Sz. \&Palcsu, L. (2017). Geochemistry of dissolved gases from the Eastern Carpathians-Transylvanian Basin boundary.Chemical Geology, 469, 117-128, 10.1016/j.chemgeo.2016.12.019

Jaffe, L.A., Hilton, D.R., Fischer, T.P.\& Hartono, U. (2004). Tracing magma sources in an arc-arc collision zone: Helium and carbon isotope and relative abundance systematics of theSanhihe Arc, Indonesia. Geochemistry, Geophysics, Geosystems, 5(4), Q04J10, doi: 10.1029/2003GC000660

Jánosi, Cs. (1980).The hydrogeology of the inferior part of the Ciuc Basin, with focus on the mineral water springs.(Doctoral dissertation). Retrieved from Faculty of Biology and Geology. Cluj-Napoca. Babes-Bolyai University. (In Romanian)

Jánosi Cs., Berszán J.\& Péter É.(2011). The mineral baths of Ciomadul Mountains, Acta Siculica 2011, Miercurea Ciuc, (pp.41-56) In Hungarian.

Karátson, D.\& Timár, G. (2005). Comparative volumetric calculations of two segments of the Carpathian Neogene/Quaternary volcanic chain using SRTM elevation data: implications for erosion and magma output rates.Zeitschrift fur Geomorphologie, 140, 19-35,Suppementary Issues

Karátson, D., Wulf, S., Veres, D., Magyari, E., Gertisser, R., Timár-Gabor A. et al. (2016). The latest explosive eruptions of Ciomadul (Csomád) volcano, East Carpathians-A tephrostratigrapic approach for the 51-29 ka BP time interval, Journal of Volcanology and Geothermal Research, 319, 29-51, 10.1016/j.jvolgeores.2016.03.005

Kato, A., Terakawa, T., Yamanaka, Y., Maeda, Y., Horikawa, S., Matsushiro, K. et al. (2015). Preparatory and precursory processes leading up to the 2014 phreatic eruption of Mount Ontake. Japan. Earth, Planets and Space, 67, 111, doi: 10.1186/s40623-015-0288-x

Kennedy, B.M., van Soest, M.C., (2006). A helium isotope perspective on the Dixie Valley, Nevada, hydrothermal system. Geothermics, 35(1), 26-43, doi:

10.1016/j.geothermics.2005.09.004.

Kiss, B., Harangi, Sz, Ntaflos, T., Mason, P. \& Pál-Molnár, E. (2014). Amphibole perspective to unravel pre-eruptive processes and conditions in volcanic plumbing systems beneath intermediate arc volcanoes: a case study from Ciomadul volcano (SE Carpathians). Contributions to Mineralogy and Petrology, 167(986). doi:10.1007/s00410-014-0986-6.

Kis B.M. , Ionescu, A., Cardellini, C., Harangi, Sz., Baciu, C., Caracausi,C. \& Viveiros, F. (2017). Quantification of carbon dioxide emissions of Ciomadul, the youngest volcano of the Carpathian-Pannonian Region (Eastern-Central Europe, Romania).Journal of Volcanology and Geothermal Research, 341, 119-130, doi: 10.1016/j.jvolgeores.2017.05.025

Konstantinou, K.I., Lin, C-H. \& Liang, W-T. (2007). Seismicity characteristics of a potentially active Quaternary volcano: The Tatun Volcano Group, northern Taiwan, Journal of Volcanology and Geothermal Research, 160, 300-318, doi:

10.1016/j.volgeores.2006.09.009. 
Lee, H., Muirhead, J., Fischer, T.P., Ebinger, C.J., Kattenhorn, S.A., Sharp, Z.D. et al. (2016). Massive and prolonged deep carbon emissions associated with continental rifting. Nature Geoscience, 9, 145-149. doi: 10.1038/ngeo2622.

Lewicki, J.L. Fischer, T.,Williams S.N. (2000). Chemical and isotopic compositions of fluid at Cumbal Volcani, Colombia: Evidence for magmatic contribution. Bulletin of Volcanology, 62, 347-361, doi:10.1007/s004450000100

Liotta,M.\& Martelli,M. (2012). Dissolved gases in brackish thermal waters: an improved analytical method.Geofluids, 12, 236-244, doi: 10.1111/j.1468-8123. 2012.00365.x.

Lin, C.H. \& Pu, H.C. (2016). Very-long-period seismic signals at the Tatun Volcano Group, northern Taiwan. Journal of Volcanology and Geothermal Research, 328, 230-236, doi: 10.1016/j.volgeores.2016.11.007

Lukács, R., Guillong, M., Schmitt A.K., Molnár K., Bachman O., Harangi Sz. (2018). LaICP-MS and SIMS U-Pb and U-Th zircon geochronological data of Late Pleistocene lava domes of the Ciomadul Volcanic Dome Complex (Eastern Carpathians). Data in Brief. 18, 808-813, doi: 10.16/j.dib.2018.03.100

Mandarano, M., Paonita, A., Martelli, M.,Viccaro, M., Nicotra, E. \&Millar I..L., (2016). Revealing magma degassing below closed-conduit active volcanoes: Geochemical features of volcanic rocks versus fumarolic fluids at Vulcano(Aeolian Islands, Italy). Lithos, 248-251, 272-287, doi: 10.1016/j.lithos.2016.01.026.

Martelli, M., Nuccio, P.M., Stuart, F.M., Burgessd, R., Ellamc R.M. \& Italiano F. (2004).Helium-strontium isotope constraints on mantle evolution beneath the Roman Comagmatic Province, Italy. Earth and Planetary Science Letters. 224, 295 - 308

Marty B. \& Giggenbach, W.F. (1990). Major and rare gases at White Island volcano, New Zealand: origin and flux of volatiles. Geophysical Research Letters, 17, 247-250, doi:10.1029/GL017i003p00247

Marty B. \& Jambon, A. (1987). C/3He in volatile fluxes from the solid Earth: Implications for carbon geodynamics. Earth and Planetary Science Letters, 83, 16-26, doi: 10.1016/0012$821 \mathrm{X}(87) 90047-1$

Mason, E., Edmonds, M., Turchyn, A. (2017). Remobilization of crustal carbon may dominate volcanic arc emissions, Science, 357, 290-294, doi: 10,1126/science.aan5049

Mason, P., Downes, H., Thirlwall, M.F., Seghedi, I., Szakács, A., Lowry, D., Mattey, D., (1996). Crustal assimilation as a major petrogenetic process in the East Carpathian Neogene and Quaternary Continental Margin Arc, Romania

Mațenco L. \& Bertotti G. (2000). Tertiary tectonic evolution of the external East Carpthians (Romania).Tectonophysics, 316(3-4), 255-286, 10.1016/S0040-1951(99)00261-9

Mațenco L., Bertotti G, Leever K., Cloething S, Schmidt SM, Tărăpoancă M.\& Dinu C. (2007). Large-scale deformation in a locked collisional boundary: interplay between 
subsidence and uplift, intraphase stress, and inherited litospheric structure in the large stage of the SE Carpathian evolution. Tectonics, 26(4), 1-29, doi: 10.1029/2006TC001951

Mazot, A., Rouwet, D., Taran, Y., Inguaggiato, S.\& Varley, N. (2011). $\mathrm{CO}_{2}$ and He degassing at El Chicón volcano, Chiapas, Mexico: gas flux, origin and relationship with local and regional tectonics.Bulletin of Volcanology, 73, 423-441, doi 10.1007/s00445-010-0443-y

Melián G., Tassi, F., Pérez, N., Hernández, P., Sortino, F., Vaselli, O. et al. (2012).A magmatic source for fumaroles and diffuse degassing from the summit crater of Teide Volcano (Tenerife, Canary Islands): a geochemical evidence for the 2004-2005 seismicvolcanic crisis.Bulletin of Volcanology, 74, 1465-1483, doi:10.1007/s00445-012-0613-1.

Molnár, K., Harangi, Sz., Lukács R., Dunkl I., Schmitt, A.K., Kiss B., Garamhegyi T. \& Seghedi I.(2018). The onset of the volcanism in the Ciomadul Volcanic Dome Complex (Eastern Carpathians): eruption chronology and magma type variation. Journal of Volcanology and Geothermal Research, 354, 39-56, doi10.1016/j.jvolgeores.2018.01.025

Molnár, K., Lukács, R., Dunkl, I., Schmitt, A.K., Kiss, B., Seghedi, I., Szepesi, J. and Harangi, S. (2019). Episodes of dormancy and eruption of the Late Pleistocene Ciomadul volcanic complex (Eastern Carpathians, Romania) constrained by zircon geochronology., 373: 133-147. (2019)

Moriya, I., Okuno, M., Nakamura, T., Ono, K. \& Seghedi, I. (1996). Radiocarbon ages of charcoal fragments from the pumice flow deposits of the last eruption of Ciomadul Volcano, Romania.Summaries of Researches Using AMS at Nagoya University, 3,252-255.

Moriya, I., Okuno, M., Nakamura, E., Szakács, A. \& Seghedi, I. (1995). Last eruption and its ${ }^{14} \mathrm{C}$ age of Ciomadul Volcano, Romania. Summaries of Researches Using AMS at Nagoya University, 6, 82-91.

Moussallam, Y., Bani, P., Schipper, C.I., Cardona, C., Franco, L., Barnie, T., Amigo, A., Curtis, A., Peters, N., Aiuppa, A., Giudice, G. \& Oppenheimer, C. (2018). Unrest and the Nevados de Chillan volcanic complex: a failed or yet to unfold magmatic eruption.

Volcanica, 1(1), 19-32, 10.30909/vol.01.01.1932

Nicolaescu, V. (1973). Contributions to the knowledge on the Cretaceous flysch of the western part of Bodoc Mts. Studii și cercetări Geologie Geofizica, Geografie, 18(2), 479-488, (In Romanian)

O'Nions, R.K.\& Oxburgh, E.R. (1988).Helium, volatile fluxes and the development of the continental crust.Earth and Planetary Science Letters, 90(3), 331-347. doi: 10.1016/0012821X(88)90134-3

Oppenheimer, C., Fischer, T. P. \& Scaillet, B. (2014). Volcanic degassing: process and impact. In H.D. Holland, \& K.K. Turekian (Eds.),Treatise on Geochemistry, 2nd Edition, Oxford, (pp. 111-179), Elsevier, doi: 10.1016/B978-0-08-095975-7.00304-1

Ozima, M.\& Podosek, FA. (2004). Noble gas geochemistry. Cambridge, Cambridge University Press 
Palcsu, L., Vető, I., Futó, I., Vodila, G., Papp, L., Major, Z. (2014). In-reservoir mixing of mantle-derived $\mathrm{CO}_{2}$ and metasedimentary $\mathrm{CH}_{4}-\mathrm{N}_{2}$ fluids. Noble gas and stable isotope study of two multistached fields (Pannonian Basin System, W-Hungary). Marine and Petroleum Geology, 54, 216-227, doi: 10.1016/j.marpetgeo.2014.03.013

Panaiotu, C.G., Jicha, B.R., Singer, B.S., Tugui, A., Seghedi, I., Panaiotu, A.G. \& Necula, C. (2013). ${ }^{40} \mathrm{Ar} /{ }^{39} \mathrm{Ar}$ chronology and paleomagnetism of Quaternary basaltic lavas from the Perşani Mountains (East Carpathians). Physics of the Earth and Planetary Interiors, 221, 124.10.1016/j.pepi.2013.06.007

Panaiotu, C.G., Pécskay, Z., Hambach, U., Seghedi, I., Panaiotu, C.E., Tetsumaru, I., Orleanu, M. \& Szakács, A. (2004). Short-lived Quaternary volcanism in the Persani Mountains (Romania) revealed by combined K-Ar and paleomagnetic data. Geologica Carpathica, 55(4), 333-339.

Paonita, A., Caracausi, A., Iacono-Marziano, G., Martelli, M. \& Rizzo, A. (2012).Geochemical evidence for mixing between fluids exsolved at different depths in the magmatic system of Mt.Etna (Italy).Geochimica et Cosmochimica Acta, 84, 380-394. doi:10.1016/j.gca.2012.01.028

Paonita, A., Longo, M., Bellomo, S., D’Alessandro, W. \& Brusca, L. (2016).Dissolved inert gases $\left(\mathrm{He}, \mathrm{Ne}\right.$ and $\mathrm{N}_{2}$ ) as markers of groundwater flow and degassing areas at Mt.Etna volcano (Italy).Chemical Geology, 443, 10-20, doi: 10.1016/j.chemgeo.2016.09.018

Parello, F., AllardP., D’AlessandroW., C.Federico, C.,Jean-BaptisteP. \&Catani, O. (2000). Isotope geochemistry of Pantelleria volcanic fluids, Sicily Channel rift: a mantle volatile endmember for volcanism in southern Europe, Earth and Planetary Science Letters, 180 (3-4), 325-339, 10.1016/S0012-821X(00)00183-7

Pécskay, Z., Lexa, J., Szakács, A., Seghedi, I., Balogh, K., Konecny, V., Zelenka, T., Kovacs, M., Póka, T., Fülöp, A., Márton, E., Panaiotu, C. \& Cvetkovic, V. (2006). Geochronology of Neogene magmatism in the Carpathian arc and intra-Carpathian area. Geologica Carpathica, 57 (6), 511-530.

Pedroni, A., Hammerschidt, K.\& Friedrichsen, H.(1999). He, Ne, Ar and C isotope systematics of geothermal emanations in the Lesser Antilles Islands Arc. Geochimicaet Cosmochimica Acta, 63, 515-532, doi:10.1016/S0016-7037(99)00018-6

Pik, R. \& Marty, B.(2008). Helium isotopic signature of modern and fossil fluids associated with the Corinth rift fault zone (Greece): Implication for fault connectivity in the lower crust. Chemical Geology, 266 (1), 67-75, 10.1016/j.chemgeo.2008.09.024

Pizzino, L., Galli, G., Mancini, C., Quattrocchi, F. \& Scarlato, P. (2002).Natural gas hazard $\left(\mathrm{CO}_{2}\right.$ and $\left.{ }^{222} \mathrm{Rn}\right)$ within a quiescent volcanic region and its relations with tectonics: the case of Ciampino-Marino Area, Albani Hills Volcano, Italy.Natural Hazards, 27, 257-287, 10.1023/A:1020398128649

Popa M., Radulian, M., Szakács A., Seghedi I. \& Zaharia B. (2012). New seismic and tomography data inthe southern part of the Harghita Mountains (Romania, Southeastern 
Carpathians): connection with recent volcanic activity.Pure Applied Geophysics, 169, 15571573, doi: 10.1007/s00024-011-0428-6

Poorter, R., Varekamp, J., Poreda, R., Van Bergen, M.\& Kreuen, R. (1991). Chemical and isotopic compositions of volcanic gases from the east Sunda and Banda arcs, Indonesia.Geochimica et Cosmochimica Acta, 55(12), 3798-3807, doi:10.1016/00167073(91)90075-G

Rădulescu, D., Peter, E., Stanciu, C., Stefanescu, M., \& Veliciu, S. (1981). Discussion on the geothermal anomalies within South Harghita Mountains.Studii si Cercetari Geologie.,

Geografie, Geofizica, Seria Geologie, 26(2), 169-184, In Romanian.

Rizzo, A. L., Barbieri, F., Carapezza, M.L., Di Piazza, A., Francalanci, L., Sortino, F. \& D'Alessandro, W. (2015).New mafic magma refilling a quiescent volcano: Evidence from He-Ne-Ar isotopes during the 2011-2012 unrest at Santorini, Greece. Geochemistry, Geophysics, Geosystems, 16, 798-814, 10.1002/2014GC005653

Royden, L.H., Horváth, F., Burchfiel, B.C. (1982). Transform faulting, extension and subduction in the Carpathian Pannonian Region, GSA Bulletin, 93, 8, 717-725, doi: 10.1130/0016-7606(1982)93

Roulleau, E., Sano, Y., Takahata, N., Yang, F.T., Takahashi, H.A. (2015). He, Ar, N and C isotope compositions in Tatun Volcanic Group (TVG), Taiwan: evidence for an important contribution of pelagic carbonates in the magmatic source. Journal of Volcanology and Geothermal Research, 303, 7-15, doi:10.1016/j.volgeores.2015.07.017

Roulleau, E., Tardani, D., Sano, Y., Takahata, N., Vinet, N., Bravo, et al. (2016). New insight from noble gas and stable isotopes of geothermal/hydrothermal fluids at Caviahue-Copahue Volcanic Complex: Boilingsteam separation and water-rock interaction at shallow depth, Journal of Volcanology and Geothermal Research, 328, 70-83, doi:

10.1016/j.jvolgeores.2016.10.007

Rouwet, D., Sandri, L., Marzocchi, W., Gottsmann, J., Selva, J., Tonini, R. et al. (2014).Recognizing and tracking volcanic hazards related to non-magmatic unrest: a review.Journal of Applied Volcanology, 3, 1-17, 10.1186/s13617-014-0017-3

Rouwet D., Hidalgo S., Joseph E.P., González-Ilama G. (2017).Fluid Geochemistry and Volcanic Unrest: Dissolving the Haze in Time and Space. In: Advances in Volcanology, Berlin, Heidelberg,Springer, doi:10.1007/11157_2017_12

Rudnick R.L. \&Gao S., (2003). Composition of the continental crust. Treatise in Geochemistry, 3:1-64, DOI: 10.1016/B0-08-043751-6/03016-4

Ruzié, L., Moreira, M.\& Crispi, O. (2012). Noble gas isotopes in hydrothermal volcanic fluids of La Soufriére volcano, Guadeloupe, Lesser Antilles arc.Chemical Geology, 304-305, 158-165, doi:10.1016/j.chemgeo.2012.02.012

Sano, Y., Hirabayashi, J.-I., Oba, T.\& Gamo, T.(1994).Carbon and helium isotopic ratios at Kusatsu-Shirane volcano, Japan, Applied Geochemistry, 9, 371-377 doi: 10.1016/088329274)90059-0 
Sano Y., Kagoshima T., Takahata N., Nishio Y., Roulleau, E., Pinti, D.L.\& Fischer, T.P. (2015).Ten-year helium anomaly prior to the 2014 Mt. Ontake eruption.Scientific Reports, 5, 13069, doi:10.1038/srep13069

Sano Y.\& Marty B.(1995). Origin of carbon in fumarolic gas from island arcs, Chemical Geology, 119, 265-214,doi: 10.1016/0009-2541(94)00097-R

Sano Y.\& Wakita H.(1985). Geographical distribution of 3He/4He ratios in Japan: Implications for arc tectonics and incipient magmatism, Journal of Geophysical Research, 90, 8729-8741, 10.1029/JB090iB10p08729F

Sano, Y.\& Williams S.N. (1996). Fluxes of mantle and subducted carbon along convergent plate boundaries.Geophysical Research Letters, 23, 2749-2752, doi: 10.1029/96GL02260

Sarbu, S., Aerts J.W., Flot, J.F., Van Spanning, R.J.M., Baciu C., Ionescu, A., Kis, B.M. et al. (2018). Sulfur Cave (Romania), an extreme environment with microbial mats in a $\mathrm{CO}_{2}-\mathrm{H}_{2} \mathrm{~S} / \mathrm{O}$ gas chemocline dominated by mycobacteria.International Journal of Speleology, 42(2), 173182, doi: 10.5038/1827-806X.47.2.2164

Seghedi, I., Mațenco, L., Downes, H., Mason, P.R.D., Szakács, A.\& Pécskay, Z. (2011). Tectonic significance of changes in post-subduction Pliocene-Quaternary magmatism in the south east part of the Carpathian-Pannonian Region.Tectonophysics, 502, 146-157, 10.1016/j.tecto.2009.12.003

Seghedi, I.\& Szakács, A.(1994). The Upper Pliocene-Pleistocene effusive and explosive basalticvolcanism from the Perşani Mountains. Romanian Journal of Petrology, 76, 101-107

Seghedi, I., Popa, R.G., Panaiotu, C.G., Szakács, A.\& Pécskay, Z. (2016). Short-lived eruptive episodes during the construction of a Na-alkalic basaltic field (Perșani Mountains, SE Transylvania, Romania, Bulletin of Volcanology, 78, 69 doi:10.1007/s00445-016-1063-y

Seghedi, I., Downes, H., Szakács, A., Mason, P.R.D., Thirlwall, M.F., Rosu, E., Pécskay, Z., Marton, E.\& Panaiotu, C. (2004). Neogene-Quaternary magmatism and geodinamics in the Carpathian-Pannonian region: a synthesis. Lithos, 72, 117-146.

Seghedi, I., Downes, H., Harangi, Sz., Mason, P.R.D. \& Pécskay, Z. (2005) Geochemical response of magmas to Neogene-Quaternary continental collision in the CarpathianPannonian region: A review. Tectonophysics, 410, 485 - 499, doi:10.1016/j.tecto.2004.09.015

Seghedi, I., Szakács, A., Udrescu, C., Stoian, M., Graban, G. (1987). Trace element geochemistry of the South Harghita volcanic (East Carpathians). Calc-alkaline and shoshinitic associations. Dari de Seama a Sedintelor Institutului Geologic si Geofizic, 72, 73, 1

Shaw, A.M., Hilton, D.R., Fischer, T.P., Walker, J.A. \& Alvarado, G.E. (2003).Contrasting $\mathrm{He}-\mathrm{C}$ relationships in Nicaragua and Costa Rica: Insights into $\mathrm{C}$ cycling through subduction zones.Earth and Planetary Science Letters, 214, 499-513, doi: 10.1016/S0012821X(03)00401-1 
Sherwood-Lollar, B., Ballentine, C.J., Onions, R.K. (1997). The fate of mantle-derived carbon in a continental sedimentary basin: intergration of $\mathrm{C}$ He relationships and isotope signatures. Geochimica et Cosmochimica Acta, 61, 11, 2295-2307, doi: 10.1016/S00167037(97) 00083-5

Shimizu, A., Sumino, H., Nagao, K., Notsu, K., Mitropoulos, P. (2005). Variation in noble gas isotopic composition of gas samples from the Aegean arc, Greece. Journal of Volcanology and Geothermal Research, 140, 321-339.

Snyder, G., Poreda, R., Hunt, A.\& Fehn, U. (2001).Regional variations in volatile composition: isotopic evidence for carbonate recycling in the Central American volcanic arc. Geochemistry, Geophysics, Geosystems, 2, 1057, doi: 10.1029/2001GC000163

Symonds, R.B., Poreda, R.J., Evans, W.C., Janik, C.J. \& Ritchie, B.E. (2003). Mantle and crustal sources of carbon, nitrogen and noble gases in Cascade-Range and Aleutian-Arc volcanic gases.US Geological Survey Open-File Report, 03-436

Sorey, M.L., Evans, W.C., Kennedy, B.M., Farrar, C.D., Hainsworth, L.J.\& Hausback, B.(1998). Carbon dioxide and helium emission from a reservoir of magmatic gas beneath Mammoth Mountain, California. Journal of Geophysical Research, Solid Earth, 103(7), $15303-15323$

Sparks, S., Cashman, K. (2017). Dynamic magma systems: implications for forecasting volcanic activity. Elements, 13, 1, 35-40, doi:10.2113/gselements.13.1.35

Sparks, R.S.J., Folkes, C.B., Humphreys, M.C.S., Barfod, D.N., Clavero, J., Sunagua, M.C., McNutt, S.R., \& Pritchard, M.E. (2008). Uturuncu volcano, Bolivia: Volcanic unrest due to mid-crustal magma intrusion. American Journal of Science, 308, 727-769, doi:10.2475/06.2008.01.

Sturchio, N.C., Williams, S.N. \&Sano, Y. (1993). The hydrothermal system of Volcan Purace, Colombia.Bulletin of Volcanology, 55, 289-296, doi:10.1007/BF00624356

Szakács A.\& Seghedi I. (1987). Base surge deposits in the Ciomadul Massif (South Harghita Mountains), Dari de Seama ale sedintelor Institutului Geologic Geofizic, 74(1), 175-180

Szakács A.\& Seghedi I.(1995). The Călimani-Gurghiu-Harghita volcanic chain, East Carpathians, Romania: volcanological features. Acta Volcanologica, 7, 145-153

Szakács, A., Seghedi, I. (2013). The relevance of volcanic hazard in Romania: is there any? Environmental Engineering and Management Journal. 12, 125-135. doi:

0,30638/eemj.2013.015

Szakács A., Seghedi I. \& Pécskay Z.(1993). Pecularities of South Harghita Mts. as terminal segment of the Carpathian Neogene to Quaternary volcanic chain, Rev. Roum de Géol., 37, $21-36$

Szakács A., Seghedi I., Pécskay Z. \& Mirea V. (2015). Eruptive history of a low-frequency and low-output rate Pleistocene volcano, Ciomadul, South Harghita Mts., Romania, Bulletin of Volcanology, 77(12), doi: 10.1007/s00445-014-0894-7 
Tassi, F., Aguilera, F., Benavente, O., Paonita, A., Chiodini, G., Caliro, S., Agusto, M., Gutierez, F., Capaccioni, B., Vaselli, O., Caselli, A.\& Saltori, O. (2016).Geochemistry of fluid discharges from Peteroa volcano (Argentina-Chile) in 2010-2015: insights into compositional changes related to the fluid source region(s), Chemical Geology, 432, 41-53, doi:10.1016/j.chemgeo.2016.04.007

Tassi F., Aguilera F., Darrah T., Vaselli O., Capaccioni B., Poreda R.J.\& Delgado Huertas A.(2010).Fluid geochemistry of hydrothermal systems in the Arica-Parinacota, Taracapa and Antofagasta regions (northern Chile).Journal of Volcanology and Geothermal Research, 192, 1-15, doi: 10.1016/j.jvolgeores.2010.02.006

Tassi, F., Aguilera, F., Vaselli, O. Darrah, T.\& Medina, E. (2011). Gas discharges from four remote volcanoes in Chile (Putana, Olca, Irruputuncu and Alitar): a geochemical survey. Annals of Geophysics, 54, doi: 10.4401/ag-5173

Tassi F., Nisi, B., Cardellini C., Capecchiacci F., Donnini M., Vaselli O., Avino R.\& Chiodini G. (2013). Diffuse soil emission of hydrothermal gases $\left(\mathrm{CO}_{2}, \mathrm{CH}_{4}, \mathrm{C}_{6} \mathrm{H}_{6}\right)$ at Solfatara crater (Campi Flegrei, Southern Italy), Applied Geochemistry, 35, 142-153, 10.1016/j.apgeochem.2013.03.020

Torgersen, T., Drenkard, S., Stute, M., Schlosser, P., Shapiro, A. (1995). Mantle Helium inGround Waters of Eastern North-America - Time and Space Constraints On Sources. Geology, 23(8), 675-678, doi: 10.1130/0091-7613(1995)023<0675:MHIGWO>2.3.CO;2

Trasatti, E., Marra, F., Polcari, M., Etiope, G., Ciotoli, G., Darrah, T. H., Tedesco, D., S. Stramondo, S., Florindo, F., \& Ventura, G. (2018). Coeval uplift and subsidence reveal magma recharging near Rome (Italy). Geochemistry, Geophysics, Geosystems, 19, 14841498. doi:10.1029/2017GC007303

Tedesco, D., Miele, G., Sano Y.\& Tardani, J.P. (1995).Helium isotopic ratio in Vulcano island fumaroles: temporal variations in shallow level mixing and deep magmatic supply.Journal of Volcanology and Geothermal Research, 64(1-2), 117-118 doi: 10.1016/0377-0273(94)00045-I

Túri, M., Palcsu, L. Papp, L., Horváth, A., Futó, I., Molnár, M., Rinyu, L., Janovics, R., Braun, M., Hubay, K., Kis, B.M., Koltai, G. (2016). Isotope characterization of the water and sediment in volcanic lake Saint Ana, East-Carpathians, Romania. Carpathian Journal of Earth and Environmental Sciences, 11, 2, 475-484

Van Soest,M., Hilton, D.\& Kreulen, R. (1998). Tracing crustal and slab contributions to arc magmatism in the Lesser Antilles island arc using helium and carbon relationships in geothermal fluids.Geochimica et Cosmochimica Acta, 62, 3323-3335, doi: 10.1016/S00167037(98)00241-5

Vaselli, O., Downes, H., Thirlwall, M.F., Dobosi, G., Coradossi, N., Seghedi, I., Szakács, A.\& Vannucci, R. (1995). Ultramafic xenoliths in Plio-Pleistocene alkali basalts from theEastern Transylvanian Basin: depletedmantle enriched by veinmetasomatism. Journalof Petrology, 36(1), 23-53, 10.1093/petrology/36.1.23 
Vaselli, O., Minissale, A., Tassi, F., Magro, G., Seghedi, I., Ioane, D.\& Szakács, A. (2002).Ageochemical traverse across the Eastern Carpathians (Romania): constraints on the origin andevolution of the mineral waters and gas discharge. Chemical Geology, 182(2-4), 637-654, 10.1016/S0009-2541(01)00348-5

Vinkler A.P., Harangi Sz., Ntaflos T, Szakács A. (2007). Petrology and geochemistry of pumices from the Ciomadul volcano (Eastern Carpathians)-implications for petrogenetic processes, Földtani Közlöny 137(1), 103-128, In Hungarian

Wei, F., Xu, J., Shangguan Z., Pan, S., Yu, H., Wei, W., Bai, X.\& Chen, Z.(2016). Helium and carbon isotopes in the hot spring of Changbaishan Volcano, northeastern China: A material connection between Changbaishan Volcano and the west Pacific plate.Journal of Volcanology and Geothermal Research, 327, 398-406, doi: 10.1016/j.jvolgeores.2016.09.005

Wenzel, F., Lorenz, F.P., Sperner, B.\& Oncescu, M.C. (1999). Seismotectonics of the Romanian Vrancea Area. In Wenzel, F., Lungu, D., Novak, O. (Eds.) Vrancea Earthquakes: tectonics, hazard and risk mitigation.(pp.15-25), Springer Netherlands

Werner, C., Evans, W.C., Poland, M., Tucker, D.\& Doukas, M. (2009). Long-term changes in quiescent degassing at Mount Baker Volcano, Washington, USA: Evidence for a staller intrusion in 1975 and connection to a deep magma source.Journal of Volcanology and Geothermal Research, 186, 379-389, doi: 10.1016/j.jvolgeores.2009.07.006

Varekamp, J., Kreulen, r., Poorter, R.\& Bergen, M. (1992). Carbon sources in arc volcanism, with implications for the carbon cycle. Terra nova, 4, 363-373, doi: 10.1111/j.13653121.1992.tb00825.x

Wortel, M.J.R.\& Spakman, W. (2000). Subduction and slab detachment in the Mediterranean-Carpathian Region, Science, 291(5503), 10.1126/science.290.5498.1910

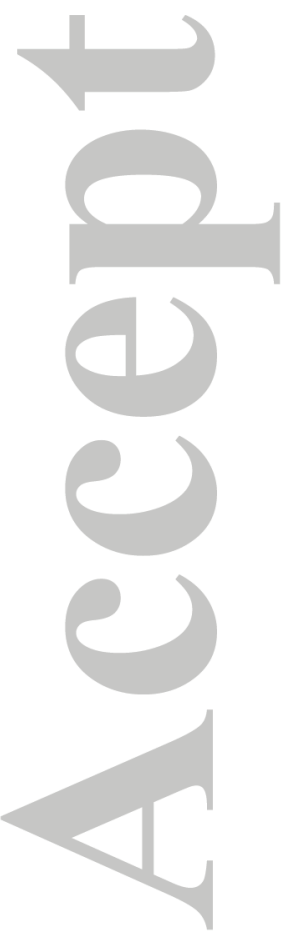


Table 1. List of the sites investigated including location names, geographical position (geographical coordinates in WGS84), type of manifestation (mofetta, bubbling pool, drilling), type of sample (free gas) and field data (temperature, pH and EC-expressed in $\mu \mathrm{S} / \mathrm{cm}$ ) where available.

\begin{tabular}{|c|c|c|c|c|c|c|c|c|}
\hline No. & Site & $\mathrm{N}$ & $\mathrm{E}$ & Type of manifestation & Sample type & $\mathrm{T}^{0} \mathrm{C}$ & $\mathrm{pH}$ & $\begin{array}{c}\mathrm{EC} \\
(\mu \mathrm{S} / \mathrm{cm})\end{array}$ \\
\hline 1 & Torjai Stinky Cave & 46.1198 & 25.9488 & mofetta & free gas & nd & nd & nd \\
\hline 2 & Timsós cave & 46.1191 & 25.9495 & mofetta & free gas & nd & nd & nd \\
\hline 3 & Gyilkos cave & 46.1218 & 25.9494 & mofetta & free gas & nd & nd & nd \\
\hline 4 & Buffogó peat bog pool & 46.1279 & 25.9504 & bubbling pool & free gas & 1 & 3 & 472 \\
\hline 5 & Buffogó peat bog & 46.1283 & 25.9504 & bubbling pool & free gas & nd & nd & nd \\
\hline 6 & Várpad - Ibolya pool & 46.1134 & 25.9600 & bubbling pool & free gas & 7.1 & 6.46 & 3220 \\
\hline $7 \mathrm{a}$ & Bálványos mofetta & 46.1118 & 25.9579 & bubbling pool & free gas & 9.7 & 4.99 & 3722 \\
\hline $7 \mathrm{~b}$ & Bálványos mofetta & 46.1118 & 25.9579 & bubbling pool & free gas & 9.7 & 4.99 & 3722 \\
\hline 8 & Bálványos pool & 46.1095 & 25.9590 & bubbling pool & free gas & 5 & 6.54 & 9360 \\
\hline 9 & $\begin{array}{c}\text { Csiszárfürdő - Iker pool } \\
\text { white }\end{array}$ & 46.1063 & 25.9514 & bubbling pool & free gas & 1.2 & 5.12 & 741 \\
\hline 10 & Csiszárfürdő - Hammas pool & 46.1065 & 25.9504 & bubbling pool & free gas & 3.6 & 5.29 & 2040 \\
\hline 11 & Csiszárfürdő - Timsós pool & 46.1063 & 25.9504 & bubbling pool & free gas & 4.7 & 5.9 & 1274 \\
\hline 12 & $\begin{array}{c}\text { Csiszárfürdő - Csokoládés } \\
\text { pool }\end{array}$ & 46.1059 & 25.9508 & bubbling pool & free gas & 2.7 & 4.2 & 837 \\
\hline 13 & Mikesfürdő - Vallató pool & 46.1170 & 25.9281 & bubbling pool & free gas & 5 & 6.16 & 2300 \\
\hline 14 & $\begin{array}{c}\text { Mikesfürdő - Vallató } \\
\text { mofetta }\end{array}$ & 46.1180 & 25.9283 & mofetta & free gas & 5 & 2.72 & 1620 \\
\hline 15 & Mikesfürdő - Hammas pool & 46.1168 & 25.9340 & bubbling pool & free gas & 1.9 & 2.96 & 968 \\
\hline 16 & Mikesfürdő - Bükkös pool & 46.1161 & 25.9349 & bubbling pool & free gas & 2.3 & 3.6 & 584 \\
\hline 17 & $\begin{array}{c}\text { Apor lányok feredeje - Small } \\
\text { pool }\end{array}$ & 46.1150 & 25.9496 & bubbling pool & free gas & 4.8 & 1.71 & 3620 \\
\hline 18 & $\begin{array}{c}\text { Apor lányok feredeje -spring } \\
\text { on fault } 2\end{array}$ & 46.1148 & 25.9496 & bubbling pool & free gas & 6.9 & 2.2 & 7100 \\
\hline 19 & $\begin{array}{c}\text { Apor lányok feredeje - } \\
\text { Szemvíz } 4\end{array}$ & 46.1148 & 25.9496 & bubbling pool & free gas & 4.2 & 2.6 & 2080 \\
\hline
\end{tabular}

(c) 2019 American Geophysical Union. All rights reserved. 


\begin{tabular}{|c|c|c|c|c|c|c|c|c|}
\hline 20 & Gyógyvizek & 46.1133 & 25.9504 & bubbling pool & free gas & 3.7 & 1.85 & 2780 \\
\hline 21 & Bálványos Sósmező drilling & 46.1159 & 25.9424 & drilling & free gas & nd & nd & nd \\
\hline 22 & $\begin{array}{c}\text { Bálványos Sósmező drilling } \\
2\end{array}$ & 46.1159 & 25.9424 & drilling & free gas & nd & nd & nd \\
\hline 23 & \begin{tabular}{|c} 
Bálványos Sósmezö drilling \\
3
\end{tabular} & 46.1159 & 25.9424 & drilling & free gas & nd & nd & nd \\
\hline 24 & St Anna crater rim & 46.1310 & 25.8936 & mofetta & free gas & nd & nd & nd \\
\hline 25 & Jajdon pool & 46.0701 & 25.9538 & bubbling pool & free gas & 4.6 & 7.3 & 1489 \\
\hline 26 & Jajdon mofetta & 46.0699 & 25.9538 & mofetta & free gas & nd & nd & nd \\
\hline 27 & Băile Tușnad mofetta & 46.1421 & 25.8518 & mofetta & free gas & nd & nd & nd \\
\hline 28 & Lăzărești Nyírfürdő mofetta & 46.1831 & 25.9520 & mofetta & free gas & nd & nd & nd \\
\hline 29 & Lăzărești Nyírfürdő pool & 46.1831 & 25.9518 & bubbling pool & free gas & 6.6 & 5.96 & 768 \\
\hline 30 & Lăzărești Nyírfürdő pool 2 & 46.1829 & 25.9519 & bubbling pool & free gas & nd & nd & nd \\
\hline 31 & Ciucsângeorgiu mofetta & 46.3363 & 25.9642 & mofetta & free gas & nd & nd & nd \\
\hline
\end{tabular}

Note. nd=not determined. 
Table 2.. Chemical composition of the different gas samples, expressed in \%.

\begin{tabular}{|c|c|c|c|c|c|c|c|c|c|c|c|c|c|}
\hline No. & Site & Campaign & Laboratory & $\mathrm{H}_{2} \mathrm{~S}$ & $\mathrm{He}$ & $\mathrm{Ne}$ & $\mathrm{H}_{2}$ & $\mathrm{CO}$ & $\mathrm{CH}_{4}$ & $\mathrm{~N}_{2}$ & $\mathrm{O}_{2}$ & $\mathrm{CO}_{2}$ & Source \\
\hline \multirow[t]{3}{*}{1} & $\begin{array}{c}\text { Torjai Stinky } \\
\text { Cave }\end{array}$ & $\begin{array}{c}1 \text { st } \\
\text { Campaign }\end{array}$ & Debrecen & nd & $6.3 \times 10-4$ & $3.5 \times 10-5$ & nd & nd & nd & nd & nd & nd & this work \\
\hline & $\begin{array}{c}\text { Torjai Stinky } \\
\text { Cave }\end{array}$ & & Rome & $5.2 \times 10-2$ & $7.0 \times 10-4$ & $4.0 \times 10-4$ & $2.0 \times 10-5$ & & $8.4 \times 10-1$ & $1.6 \times 101$ & $4.9 \mathrm{E}+00$ & 78.09 & this work \\
\hline & $\begin{array}{c}\text { Torjai Stinky } \\
\text { Cave }\end{array}$ & $\begin{array}{c}\text { 2nd } \\
\text { Campaign }\end{array}$ & Palermo & $1.8 \times 10-2$ & $6.1 \times 10-4$ & $6.4 \times 10-7$ & nd & $\begin{array}{c}5.0 \\
\times 10-4 \\
\end{array}$ & $8.9 \times 10-1$ & $1.2 \times 101$ & $2.9 \mathrm{E}+00$ & 82.68 & this work \\
\hline \multirow[t]{3}{*}{2} & Timsós cave & $\begin{array}{c}1 \text { st } \\
\text { Campaign }\end{array}$ & Debrecen & nd & $6.9 \times 10-4$ & $2.9 \times 10-5$ & nd & nd & nd & nd & nd & nd & this work \\
\hline & Timsós cave & & Rome & $6.8 \times 10-2$ & $7.0 \times 10-4$ & $3.0 \times 10-4$ & $3.0 \times 10-5$ & & $8.4 \times 10-1$ & $1.2 \times 101$ & $3.8 \mathrm{E}+00$ & 83.05 & this work \\
\hline & Timsós cave & $\begin{array}{c}\text { 2nd } \\
\text { Campaign }\end{array}$ & Palermo & nd & $6.3 \times 10-4$ & $4.8 \times 10-5$ & nd & $\begin{array}{c}1.0 \\
\times 10-4\end{array}$ & $9.3 \times 10-1$ & $2.1 \mathrm{E}+00$ & $7.3 \times 10-2$ & 95.24 & this work \\
\hline \multirow[t]{2}{*}{3} & Gyilkos cave & $\begin{array}{c}1 \text { st } \\
\text { Campaign }\end{array}$ & Debrecen & nd & $5.6 \times 10-4$ & $4.0 \times 10-4$ & nd & nd & nd & nd & nd & nd & this work \\
\hline & Gyilkos cave & & Rome & nd & $6.0 \times 10-4$ & $1.0 \times 10-3$ & $4.0 \times 10-5$ & nd & $1.1 \times 10-1$ & $3.8 \times 101$ & $9.5 \mathrm{E}+00$ & 52.54 & this work \\
\hline \multirow[t]{3}{*}{4} & $\begin{array}{c}\text { Buffogó peat } \\
\text { bog pool }\end{array}$ & $\begin{array}{c}1 \text { st } \\
\text { Campaign }\end{array}$ & Debrecen & nd & $6.7 \times 10-4$ & $8.8 \times 10-7$ & nd & nd & nd & nd & nd & 64.98 & this work \\
\hline & $\begin{array}{c}\text { Buffogó peat } \\
\text { bog pool }\end{array}$ & & Rome & nd & $8.0 \times 10-4$ & $5.0 \times 10-4$ & $4.0 \times 10-5$ & nd & $9.7 \times 10-1$ & $2.6 \times 101$ & $7.6 \mathrm{E}+00$ & 64.98 & this work \\
\hline & $\begin{array}{c}\text { Buffogó peat } \\
\text { bog pool }\end{array}$ & $\begin{array}{c}\text { 2nd } \\
\text { Campaign }\end{array}$ & Palermo & $5.0 \times 10-4$ & $7.1 \times 10-4$ & $7.9 \times 10-4$ & nd & nd & $1.3 \mathrm{E}+00$ & $1.9 \mathrm{E}+00$ & $1.5 \times 10-1$ & 95.50 & this work \\
\hline 5 & $\begin{array}{l}\text { Buffogó peat } \\
\text { bog }\end{array}$ & $\begin{array}{c}1 \text { st } \\
\text { Campaign }\end{array}$ & Debrecen & nd & $9.4 \times 10-4$ & $2.0 \times 10-6$ & nd & nd & nd & nd & nd & nd & this work \\
\hline \multirow[t]{2}{*}{6} & $\begin{array}{c}\text { Várpad - Ibolya } \\
\text { pool }\end{array}$ & $\begin{array}{c}1 \text { st } \\
\text { Campaign }\end{array}$ & Debrecen & nd & $5.9 \times 10-5$ & $1.4 \times 10-4$ & nd & nd & nd & nd & nd & 75.97 & this work \\
\hline & $\begin{array}{c}\text { Várpad - Ibolya } \\
\text { pool }\end{array}$ & & Rome & nd & $2.0 \times 10-4$ & $5.0 \times 10-4$ & $2.0 \times 10-5$ & nd & $2.2 \times 10-1$ & $1.8 \times 101$ & $5.7 \mathrm{E}+00$ & 75.97 & this work \\
\hline $7 \mathrm{a}$ & $\begin{array}{c}\text { Bálványos } \\
\text { mofetta }\end{array}$ & $\begin{array}{c}1 \text { st } \\
\text { Campaign }\end{array}$ & Debrecen & nd & $8.3 \times 10-4$ & $1.8 \times 10-6$ & nd & nd & nd & nd & nd & nd & this work \\
\hline \multirow[t]{3}{*}{$7 b$} & $\begin{array}{c}\text { Bálványos } \\
\text { mofetta }\end{array}$ & $\begin{array}{c}1 \text { st } \\
\text { Campaign }\end{array}$ & Debrecen & nd & $4.6 \times 10-4$ & $1.8 \times 10-4$ & nd & nd & nd & nd & nd & 94.87 & this work \\
\hline & $\begin{array}{c}\text { Bálványos } \\
\text { mofetta }\end{array}$ & & Rome & nd & $5.9 \times 10-3$ & $4.1 \times 10-3$ & $3.4 \times 10-2$ & nd & $6.4 \times 10-1$ & $3.7 \mathrm{E}+00$ & $8.2 \times 10-1$ & 94.87 & this work \\
\hline & Bálványos & 2nd & Palermo & nd & $1.0 \times 10-3$ & $2.5 \times 10-4$ & $1.4 \times 10-3$ & nd & $1.3 \mathrm{E}+00$ & $2.2 \times 101$ & $6.1 \mathrm{E}+00$ & 68.25 & this work \\
\hline
\end{tabular}

() 2019 American Geophysical Union. All rights reserved. 


\begin{tabular}{|c|c|c|c|c|c|c|c|c|c|c|c|c|c|}
\hline & mofetta & Campaign & & & & & & & & & & & \\
\hline \multirow[t]{2}{*}{8} & Bálványos pool & $\begin{array}{c}1 \text { st } \\
\text { Campaign }\end{array}$ & Debrecen & nd & $1.7 \times 10-3$ & $1.7 \times 10-4$ & nd & nd & nd & nd & nd & 63.84 & this work \\
\hline & Bálványos pool & & Rome & nd & $1.7 \times 10-2$ & $5.8 \times 10-3$ & $2.3 \times 10-1$ & nd & $1.7 \mathrm{E}+00$ & $2.6 \times 101$ & $8.4 \mathrm{E}+00$ & 63.84 & this work \\
\hline \multirow[t]{2}{*}{9} & $\begin{array}{l}\text { Csiszárfürdő - } \\
\text { Iker pool white }\end{array}$ & $\begin{array}{c}\text { 1st } \\
\text { Campaign }\end{array}$ & Debrecen & nd & $1.3 \times 10-3$ & $1.0 \times 10-5$ & nd & nd & nd & nd & nd & nd & this work \\
\hline & $\begin{array}{l}\text { Csiszárfürdő - } \\
\text { Iker pool white }\end{array}$ & $\begin{array}{c}\text { 2nd } \\
\text { Campaign }\end{array}$ & Palermo & nd & $9.5 \times 10-4$ & $1.1 \times 10-5$ & nd & nd & $1.7 \mathrm{E}+00$ & $1.8 \mathrm{E}+00$ & $1.7 \times 10-1$ & 94.73 & this work \\
\hline \multirow{2}{*}{10} & 11 & & Rome & $1.1 \times 10-1$ & $1.0 \times 10-2$ & $2.3 \times 10-3$ & $9.0 \times 10-4$ & nd & $1.2 \mathrm{E}+00$ & $9.8 \times 10-1$ & $3.5 \times 10-1$ & 96.72 & this work \\
\hline & $\begin{array}{l}\text { Csiszárfürdő - } \\
\text { Hammas pool }\end{array}$ & $\begin{array}{c}\text { 2nd } \\
\text { Campaign }\end{array}$ & Palermo & nd & $6.9 \times 10-4$ & $5.5 \times 10-6$ & nd & nd & $1.2 \mathrm{E}+00$ & $8.8 \times 10-1$ & $3.0 \times 10-2$ & 94.81 & this work \\
\hline \multirow[t]{2}{*}{11} & $\begin{array}{l}\text { Csiszárfürdő - } \\
\text { Timsós pool }\end{array}$ & $\begin{array}{c}1 \text { st } \\
\text { Campaign }\end{array}$ & Debrecen & nd & $1.1 \times 10-3$ & $1.2 \times 10-3$ & nd & nd & nd & nd & nd & 11.23 & this work \\
\hline & $\begin{array}{c}\text { Csiszárfürdö - } \\
\text { Timsós pool }\end{array}$ & & Rome & nd & $6.0 \times 10-4$ & $1.0 \times 10-3$ & $4.0 \times 10-5$ & nd & $1.7 \times 10-1$ & $7.0 \times 101$ & $1.9 \times 101$ & 11.23 & this work \\
\hline \multirow{2}{*}{12} & $\begin{array}{c}\text { Csiszárfürdő - } \\
\text { Csokoládés pool }\end{array}$ & & Rome & $1.7 \times 10-2$ & $1.3 \times 10-2$ & $4.6 \times 10-3$ & $2.3 \times 10-3$ & nd & $1.5 \mathrm{E}+00$ & 7.4 & $1.6 \mathrm{E}+00$ & 89.49 & this work \\
\hline & $\begin{array}{c}\text { Csiszárfürdő - } \\
\text { Csokoládés pool } \\
\end{array}$ & $\begin{array}{c}\text { 2nd } \\
\text { Campaign }\end{array}$ & Palermo & nd & $8.7 \times 10-4$ & $1.6 \times 10-5$ & nd & $\begin{array}{c}9.0 \\
\times 10-5 \\
\end{array}$ & $1.5 \mathrm{E}+00$ & $1.5 \mathrm{E}+00$ & $1.4 \times 10-1$ & 94.51 & this work \\
\hline \multirow[t]{3}{*}{13} & $\begin{array}{l}\text { Mikesfürdö - } \\
\text { Vallató pool }\end{array}$ & $\begin{array}{c}1 \text { st } \\
\text { Campaign }\end{array}$ & Debrecen & nd & $4.5 \times 10-4$ & $8.5 \times 10-6$ & nd & nd & nd & nd & nd & 41.34 & this work \\
\hline & $\begin{array}{l}\text { Mikesfürdő - } \\
\text { Vallató pool }\end{array}$ & & Rome & nd & $5.9 \times 10-3$ & nd & $6.0 \times 10-4$ & nd & $5.5 \mathrm{E}-01$ & $4.6 \times 101$ & $1.3 \times 101$ & 41.34 & this work \\
\hline & $\begin{array}{l}\text { Mikesfürdö - } \\
\text { Vallató pool }\end{array}$ & $\begin{array}{c}\text { 2nd } \\
\text { Campaign }\end{array}$ & Palermo & nd & $4.3 \times 10-4$ & $1.4 \times 10-5$ & nd & nd & $1.2 \mathrm{E}+00$ & $1.8 \mathrm{E}+00$ & $1.8 \times 10-1$ & 93.95 & this work \\
\hline \multirow[t]{2}{*}{14} & $\begin{array}{c}\text { Mikesfürdő - } \\
\text { Vallató mofetta }\end{array}$ & $\begin{array}{c}\text { 1st } \\
\text { Campaign }\end{array}$ & Debrecen & nd & $3.0 \times 10-4$ & $4.0 \times 10-5$ & nd & nd & nd & nd & nd & 91.86 & this work \\
\hline & $\begin{array}{c}\text { Mikesfürdö - } \\
\text { Vallató mofetta }\end{array}$ & & Rome & $2.7 \times 10-2$ & $3.0 \times 10-4$ & $2.0 \times 10-4$ & $1.0 \times 10-5$ & nd & $9.6 \times 10-1$ & $5.2 \mathrm{E}+00$ & $1.9 \mathrm{E}+00$ & 91.86 & this work \\
\hline \multirow[t]{2}{*}{15} & $\begin{array}{l}\text { Mikesfürdö - } \\
\text { Hammas pool }\end{array}$ & $\begin{array}{c}\text { 1st } \\
\text { Campaign } \\
\end{array}$ & Debrecen & nd & $7.2 \times 10-4$ & $2.7 \times 10-6$ & nd & nd & nd & nd & nd & 87.67 & this work \\
\hline & $\begin{array}{l}\text { Mikesfürdő - } \\
\text { Hammas pool }\end{array}$ & & Rome & nd & $7.0 \times 10-4$ & $2.0 \times 10-4$ & $4.0 \times 10-5$ & nd & $9.9 \times 10-1$ & $8.5 \mathrm{E}+00$ & $2.9 \mathrm{E}+00$ & 87.67 & this work \\
\hline
\end{tabular}

() 2019 American Geophysical Union. All rights reserved. 


\begin{tabular}{|c|c|c|c|c|c|c|c|c|c|c|c|c|c|}
\hline & $\begin{array}{c}\text { Mikesfürdö - } \\
\text { Hammas pool }\end{array}$ & $\begin{array}{c}\text { 2nd } \\
\text { Campaign }\end{array}$ & Palermo & nd & $5.9 \times 10-4$ & $7.9 \times 10-6$ & nd & nd & $1.1 \mathrm{E}+00$ & $1.1 \mathrm{E}+00$ & $2.0 \times 10-3$ & 94.83 & this work \\
\hline \multirow[t]{2}{*}{16} & $\begin{array}{l}\text { Mikesfürdö - } \\
\text { Bükkös pool }\end{array}$ & $\begin{array}{c}1 \text { st } \\
\text { Campaign }\end{array}$ & Debrecen & nd & $8.0 \times 10-4$ & $6.7 \times 10-4$ & nd & nd & nd & nd & nd & 82.58 & this work \\
\hline & $\begin{array}{l}\text { Mikesfürdö - } \\
\text { Bükkös pool }\end{array}$ & $\begin{array}{c}\text { 2nd } \\
\text { Campaign }\end{array}$ & Palermo & nd & $7.7 \times 10-4$ & $3.9 \times 10-4$ & nd & $\begin{array}{c}1.0 \\
\times 10-4 \\
\end{array}$ & $1.1 \mathrm{E}+00$ & $9.9 \mathrm{E}+00$ & $2.4 \mathrm{E}+00$ & 84.33 & this work \\
\hline \multirow[t]{2}{*}{17} & $\begin{array}{c}\text { Apor lányok } \\
\text { feredeje - Small } \\
\text { pool } \\
\end{array}$ & $\begin{array}{c}1 \text { st } \\
\text { Campaign }\end{array}$ & Debrecen & nd & $1.2 \times 10-3$ & $5.0 \times 10-6$ & nd & nd & nd & nd & nd & 58.09 & this work \\
\hline & $\begin{array}{c}\text { Apor lányok } \\
\text { feredeje - Small } \\
\text { pool }\end{array}$ & & Rome & nd & $8.0 \times 10-4$ & $7.0 \times 10-4$ & $3.0 \times 10-5$ & nd & $7.7 \times 10-1$ & $3.2 \times 101$ & $9.4 \mathrm{E}+00$ & 58.09 & this work \\
\hline 17 & $\begin{array}{c}\text { Apor lányok } \\
\text { feredeje - Small } \\
\text { pool }\end{array}$ & $\begin{array}{c}\text { 2nd } \\
\text { Campaign }\end{array}$ & Palermo & $2.7 \times 10-4$ & $8.3 \times 10-4$ & $6.5 \times 10-5$ & nd & $\begin{array}{c}9.0 \\
\times 10-5\end{array}$ & $1.2 \mathrm{E}+00$ & $1.1 \mathrm{E}+00$ & $2.8 \times 10-3$ & 97.15 & this work \\
\hline \multirow[t]{3}{*}{18} & $\begin{array}{l}\text { Apor lányok } \\
\text { feredeje -spring } \\
\text { on fault } 2\end{array}$ & $\begin{array}{c}1 \text { st } \\
\text { Campaign }\end{array}$ & Debrecen & nd & $7.8 \times 10-4$ & $6.6 \times 10-5$ & nd & nd & nd & nd & nd & 98.36 & this work \\
\hline & $\begin{array}{c}\text { Apor lányok } \\
\text { feredeje -spring } \\
\text { on fault } 2\end{array}$ & & Rome & $1.7 \times 10-1$ & $9.7 \times 10-3$ & $2.2 \times 10-3$ & $3.2 \times 10-3$ & nd & $1.2 \mathrm{E}+00$ & $1.5 \times 10-1$ & $1.2 \times 10-1$ & 98.36 & this work \\
\hline & $\begin{array}{c}\text { Apor lányok } \\
\text { feredeje -spring } \\
\text { on fault } 2\end{array}$ & $\begin{array}{c}\text { 2nd } \\
\text { Campaign }\end{array}$ & Palermo & $3.5 \times 10-4$ & $6.5 \times 10-4$ & $7.8 \times 10-7$ & nd & nd & $1.2 \mathrm{E}+00$ & $8.6 \times 10-1$ & nd & 96.38 & this work \\
\hline \multirow[t]{3}{*}{19} & $\begin{array}{l}\text { Apor lányok } \\
\text { feredeje - } \\
\text { Szemvíz } 4\end{array}$ & $\begin{array}{c}1 \text { st } \\
\text { Campaign }\end{array}$ & Debrecen & nd & $1.2 \times 10-3$ & $2.8 \times 10-6$ & nd & nd & nd & nd & nd & 36.24 & this work \\
\hline & $\begin{array}{l}\text { Apor lányok } \\
\text { feredeje - } \\
\text { Szemvíz } 4\end{array}$ & & Rome & $2.0 \times 10-2$ & $7.0 \times 10-4$ & $1.0 \times 10-3$ & $2.0 \times 10-4$ & nd & $4.4 \times 10-1$ & $5.0 \mathrm{E}+01$ & 1.4 x 101 & 36.24 & this work \\
\hline & $\begin{array}{l}\text { Apor lányok } \\
\text { feredeje - } \\
\text { Szemvíz } 4 \\
\end{array}$ & $\begin{array}{c}\text { 2nd } \\
\text { Campaign }\end{array}$ & Palermo & nd & nd & nd & nd & $\begin{array}{c}6.0 \\
\times 10-5\end{array}$ & $9.2 \times 10-1$ & $2.0 \mathrm{E}+01$ & $5.0 \mathrm{E}+00$ & 74.99 & this work \\
\hline 20 & Gyógyvizek & $\begin{array}{c}1 \text { st } \\
\text { Campaign }\end{array}$ & Debrecen & nd & $8.1 \times 10-4$ & $1.6 \times 10-6$ & nd & nd & nd & nd & nd & 97.62 & this work \\
\hline
\end{tabular}

(C) 2019 American Geophysical Union. All rights reserved. 


\begin{tabular}{|c|c|c|c|c|c|c|c|c|c|c|c|c|c|}
\hline & Gyógyvizek & $\begin{array}{c}\text { 2nd } \\
\text { Campaign }\end{array}$ & Palermo & nd & $7.5 \times 10-4$ & $8.6 \times 10-4$ & $2.0 \times 10-3$ & $\begin{array}{l}1.5 \\
\times 10-4\end{array}$ & $8.9 \times 10-1$ & $1.4 \times 101$ & $3.5 \mathrm{E}+00$ & 78.42 & this work \\
\hline \multirow[t]{2}{*}{21} & $\begin{array}{l}\text { Bálványos } \\
\text { Sósmező } \\
\text { drilling } 1\end{array}$ & $\begin{array}{c}1 \text { st } \\
\text { Campaign }\end{array}$ & Debrecen & nd & $2.6 \times 10-4$ & $6.4 \times 10-4$ & nd & nd & nd & nd & nd & 79.78 & this work \\
\hline & $\begin{array}{l}\text { Bálványos } \\
\text { Sósmező } \\
\text { drilling } 1\end{array}$ & & Rome & nd & $2.0 \times 10-4$ & $5.0 \times 10-4$ & $3.0 \times 10-5$ & nd & $3.5 \times 10-2$ & $1.5 \times 101$ & $4.9 \mathrm{E}+00$ & 79.78 & this work \\
\hline \multirow[t]{2}{*}{22} & $\begin{array}{l}\text { Bálványos } \\
\text { Sósmező } \\
\text { drilling } 2\end{array}$ & $\begin{array}{c}1 \text { st } \\
\text { Campaign }\end{array}$ & Debrecen & nd & $4.4 \times 10-4$ & $5.4 \times 10-4$ & nd & nd & nd & nd & nd & 80.62 & this work \\
\hline & $\begin{array}{l}\text { Bálványos } \\
\text { Sósmezö } \\
\text { drilling } 2\end{array}$ & & Rome & nd & $2.0 \times 10-4$ & $4.0 \times 10-4$ & $3.0 \times 10-5$ & nd & $8.9 \times 10-2$ & 1.5 x101 & $4.6 \mathrm{E}+00$ & 80.62 & this work \\
\hline 23 & $\begin{array}{l}\text { Bálványos } \\
\text { Sósmező } \\
\text { drilling } 3\end{array}$ & $\begin{array}{c}1 \text { st } \\
\text { Campaign }\end{array}$ & Debrecen & nd & $6.2 \times 10-4$ & $4.7 \times 10-4$ & nd & nd & nd & nd & nd & nd & this work \\
\hline \multirow[t]{2}{*}{24} & $\begin{array}{l}\text { St Anna crater } \\
\text { rim }\end{array}$ & $\begin{array}{c}1 \text { st } \\
\text { Campaign }\end{array}$ & Debrecen & nd & $8.2 \times 10-4$ & $1.0 \times 10-3$ & nd & nd & nd & nd & nd & 22.74 & this work \\
\hline & $\begin{array}{l}\text { St Anna crater } \\
\text { rim }\end{array}$ & & Rome & nd & $6.0 \times 10-4$ & $1.0 \times 10-3$ & $4.0 \times 10-5$ & nd & $1.1 \times 10-1$ & $6.1 \times 101$ & 1.6 x101 & 22.74 & this work \\
\hline \multirow[t]{2}{*}{25} & Jajdon pool & $\begin{array}{c}1 \mathrm{st} \\
\text { Campaign }\end{array}$ & Debrecen & nd & $1.0 \times 10-3$ & $1.1 \times 10-3$ & nd & nd & nd & nd & nd & 20.50 & this work \\
\hline & Jajdon pool & & Rome & $4.1 \times 10-2$ & $8.6 \times 10-3$ & nd & $4.0 \times 10-4$ & nd & $4.0 \times 10-1$ & $6.2 \times 101$ & $1.7 \times 101$ & 20.50 & this work \\
\hline \multirow[t]{2}{*}{26} & Jajdon mofetta & $\begin{array}{c}\text { 1st } \\
\text { Campaign }\end{array}$ & Debrecen & nd & $5.9 \times 10-4$ & $1.7 \times 10-3$ & nd & nd & nd & nd & nd & 12.11 & this work \\
\hline & Jajdon mofetta & & Rome & nd & $5.8 \times 10-3$ & nd & $5.0 \times 10-4$ & nd & $1.3 \times 10-1$ & $6.9 \times 101$ & $1.9 \times 101$ & 12.11 & this work \\
\hline \multirow[t]{2}{*}{27} & $\begin{array}{l}\text { Băile Tușnad } \\
\text { mofetta }\end{array}$ & $\begin{array}{c}1 \text { st } \\
\text { Campaign }\end{array}$ & Debrecen & nd & $4.1 \times 10-4$ & $3.2 \times 10-4$ & nd & nd & nd & nd & nd & 97.97 & this work \\
\hline & $\begin{array}{l}\text { Băile Tuşnad } \\
\text { mofetta }\end{array}$ & & Rome & nd & $4.1 \times 10-3$ & $2.7 \times 10-3$ & $7.0 \times 10-4$ & nd & $5.9 \times 10-1$ & $9.2 \times 10-1$ & $5.2 \times 10-1$ & 97.97 & this work \\
\hline \multirow[t]{2}{*}{28} & $\begin{array}{l}\text { Lăzărești } \\
\text { Nyírfürdő } \\
\text { mofetta }\end{array}$ & $\begin{array}{c}1 \text { st } \\
\text { Campaign }\end{array}$ & Debrecen & nd & $1.3 \times 10-4$ & $2.0 \times 10-5$ & nd & nd & nd & nd & nd & 97.99 & this work \\
\hline & $\begin{array}{c}\text { Lăzărești } \\
\text { Nyírfürdő } \\
\text { mofetta }\end{array}$ & & Rome & $8.4 \times 10-2$ & $2.2 \times 10-3$ & $2.4 \times 10-3$ & $2.0 \times 10-4$ & nd & $7.8 \times 10-1$ & $7.1 \times 10-1$ & $4.3 \times 10-1$ & 97.99 & this work \\
\hline
\end{tabular}

(c) 2019 American Geophysical Union. All rights reserved. 


\begin{tabular}{|c|c|c|c|c|c|c|c|c|c|c|c|c|c|}
\hline 29 & $\begin{array}{c}\text { Lăzărești } \\
\text { Nyírfürdő pool }\end{array}$ & $\begin{array}{c}1 \text { st } \\
\text { Campaign }\end{array}$ & Debrecen & nd & $3.7 \times 10-4$ & $9.7 \times 10-4$ & nd & nd & nd & nd & nd & 93.14 & this work \\
\hline & $\begin{array}{c}\text { Lăzărești } \\
\text { Nyírfürdő pool }\end{array}$ & & Rome & $5.0 \times 10-3$ & $3.7 \times 10-3$ & $4.0 \times 10-3$ & $1.4 \times 10-3$ & nd & $1.3 \mathrm{E}+00$ & $4.8 \mathrm{E}+00$ & $7.3 \times 10-1$ & 93.14 & this work \\
\hline & $\begin{array}{c}\text { Lăzărești } \\
\text { Nyírfürdő pool } \\
\end{array}$ & $\begin{array}{c}\text { 2nd } \\
\text { Campaign }\end{array}$ & Palermo & nd & $1.1 \times 10-4$ & $2.7 \times 10-6$ & nd & nd & $8.1 \times 10-1$ & $1.7 \mathrm{E}+00$ & $5.0 \times 10-2$ & 96.71 & this work \\
\hline \multirow[t]{2}{*}{30} & $\begin{array}{l}\text { Lăzărești } \\
\text { Nyírfürdő pool } \\
2\end{array}$ & $\begin{array}{c}1 \text { st } \\
\text { Campaign }\end{array}$ & Debrecen & nd & $1.3 \times 10-4$ & $2.7 \times 10-5$ & nd & nd & nd & nd & nd & 97.66 & this work \\
\hline & $\begin{array}{c}\text { Lăzărești } \\
\text { Nyírfürdő pool } \\
2\end{array}$ & & Rome & $5.9 \times 10-2$ & $1.9 \times 10-3$ & $2.9 \times 10-3$ & $9.0 \times 10-4$ & nd & $7.9 \times 10-1$ & $8.6 \times 10-1$ & $6.2 \times 10-1$ & 97.66 & this work \\
\hline \multirow[t]{2}{*}{31} & $\begin{array}{c}\text { Ciucsângeorgiu } \\
\text { mofetta }\end{array}$ & $\begin{array}{c}1 \mathrm{st} \\
\text { Campaign }\end{array}$ & Debrecen & nd & $5.9 \times 10-4$ & $1.5 \times 10-3$ & nd & nd & nd & nd & nd & 6.40 & this work \\
\hline & $\begin{array}{c}\text { Ciucsângeorgiu } \\
\text { mofetta }\end{array}$ & & Rome & nd & $5.4 \times 10-3$ & nd & $5.0 \times 10-4$ & nd & $6.4 \times 10-2$ & $7.5 \times 101$ & $1.9 \times 101$ & 6.40 & this work \\
\hline 32 & $\begin{array}{l}\text { Csiszárfürdő } \\
\text { Băile Reci }\end{array}$ & & & nd & $2.3 \times 10-3$ & $2.3 \times 10-3$ & nd & nd & $8.0 \times 10-3$ & nd & nd & 99.99 & Frunzeti, 2013 \\
\hline 33 & $\begin{array}{c}\text { Gyógyvizek } \\
\text { Izvoarele } \\
\text { Tămăduitoare }\end{array}$ & & & nd & $3.5 \times 10-3$ & $4.6 \times 10-6$ & nd & nd & $1.3 \mathrm{E}+00$ & $1.4 \mathrm{E}+00$ & nd & 97.24 & Frunzeti, 2013 \\
\hline 34 & $\begin{array}{c}\text { Apor lányok } \\
\text { feredeje }\end{array}$ & & & nd & $3.5 \times 10-3$ & $1.3 \times 10-6$ & nd & nd & $1.3 \mathrm{E}+00$ & $1.9 \mathrm{E}+00$ & nd & 96.76 & Frunzeti, 2013 \\
\hline 35 & $\begin{array}{c}\text { Torjai Büdös } \\
\text { Cave (Stinky } \\
\text { Cave) }\end{array}$ & & & nd & $2.7 \times 10-3$ & $4.6 \times 10-6$ & nd & nd & $1.2 \mathrm{E}+00$ & $2.1 \mathrm{E}+00$ & nd & 96.80 & Frunzeti, 2013 \\
\hline 36 & $\begin{array}{c}\text { Mikesfürdő- } \\
\text { Hammas }\end{array}$ & & & nd & $3.3 \times 10-3$ & $5.0 \times 10-6$ & nd & nd & $1.3 \mathrm{E}+00$ & $1.5 \mathrm{E}+00$ & nd & 97.17 & Frunzeti, 2013 \\
\hline 37 & $\begin{array}{l}\text { Buffogó peat } \\
\text { bog }\end{array}$ & & & nd & $3.7 \times 10-3$ & $1.4 \times 10-6$ & nd & nd & $1.6 \mathrm{E}+00$ & $1.6 \mathrm{E}+00$ & nd & 96.80 & Frunzeti, 2013 \\
\hline 38 & Tusnad & & & nd & $5.3 \times 10-5$ & $7.3 \times 10-6$ & nd & nd & $3.0 \times 10-3$ & $4.4 \mathrm{E}+00$ & nd & 95.70 & Frunzeti, 2013 \\
\hline 39 & Tusnad Nadas & & & nd & $6.0 \times 10-6$ & nd & $3.4 \times 10-5$ & nd & $3.8 \times 10-3$ & $3.2 \times 10-1$ & $1.1 \times 10-1$ & 99.56 & $\begin{array}{l}\text { Vaselli et al., } \\
2002 \\
\end{array}$ \\
\hline 40 & Lăzărești Nyir & & & $5.0 \times 10-3$ & $7.8 \times 10-4$ & nd & $4.0 \times 10-5$ & $\begin{array}{r}2.2 \\
\times 10-5 \\
\end{array}$ & $3.4 \mathrm{E}+00$ & $7.4 \mathrm{E}+00$ & $1.4 \times 10-2$ & 89.11 & $\begin{array}{l}\text { Vaselli et al., } \\
2002\end{array}$ \\
\hline 41 & Sf Ana & & & nd & $6.9 \times 10-4$ & nd & $5.0 \times 10-6$ & $\begin{array}{r}7.0 \\
\times 10-6 \\
\end{array}$ & $6.5 \times 10-1$ & $1.6 \mathrm{E}+00$ & $4.2 \times 10-2$ & 97.69 & $\begin{array}{l}\text { Vaselli et al., } \\
2002 \\
\end{array}$ \\
\hline
\end{tabular}

(c) 2019 American Geophysical Union. All rights reserved. 


\begin{tabular}{|c|c|c|c|c|c|c|c|c|c|c|c|}
\hline 42 & Puturosul & $1.2 \times 10-2$ & $4.1 \times 10-4$ & nd & $3.7 \times 10-5$ & nd & $7.8 \times 10-1$ & $9.0 \times 10-1$ & $4.2 \times 10-2$ & 98.26 & $\begin{array}{c}\text { Vaselli et al., } \\
2002\end{array}$ \\
\hline 43 & Puturosul Sud & nd & $1.4 \times 10-3$ & nd & $9.0 \times 10-6$ & $\begin{array}{c}9.0 \\
\times 10-6\end{array}$ & $2.4 \mathrm{E}+00$ & $2.0 \mathrm{E}+00$ & $3.0 \times 10-2$ & 95.63 & $\begin{array}{c}\text { Vaselli et al., } \\
2002\end{array}$ \\
\hline 44 & Bálványos & $6.0 \times 10-3$ & $6.3 \times 10-4$ & nd & $1.5 \times 10-4$ & $\begin{array}{c}4.0 \\
\times 10-6\end{array}$ & $1.1 \mathrm{E}+00$ & $8.9 \times 10-1$ & $4.4 \times 10-2$ & 97.97 & $\begin{array}{c}\text { Vaselli et al., } \\
2002\end{array}$ \\
\hline 45 & $\begin{array}{c}\text { Torjai Büdös } \\
\text { Cave (Stinky } \\
\text { Cave) }\end{array}$ & nd & $1.1 \times 10-3$ & nd & nd & nd & $8.0 \times 10-1$ & $9.7 \times 10-1$ & $6.0 \times 10-2$ & 98.20 & $\begin{array}{c}\text { Althaus et al., } \\
2000\end{array}$ \\
\hline 46 & $\begin{array}{c}\text { Apor lányok } \\
\text { feredeje-Upper } \\
\text { pool }\end{array}$ & nd & $1.3 \times 10-3$ & nd & nd & nd & $1.2 \mathrm{E}+00$ & $1.5 \mathrm{E}+00$ & $1.8 \times 10-1$ & 97.75 & $\begin{array}{c}\text { Althaus et al., } \\
2000\end{array}$ \\
\hline 47 & $\begin{array}{c}\text { Apor lányok } \\
\text { feredeje-Lower } \\
\text { pool }\end{array}$ & nd & $1.3 \times 10-3$ & nd & nd & nd & $9.4 \times 10-1$ & $7.3 \times 10-1$ & $2.0 \times 10-2$ & 98.16 & $\begin{array}{c}\text { Althaus et al., } \\
2000\end{array}$ \\
\hline 48 & Bixad & nd & nd & nd & nd & nd & $2.3 \times 10-1$ & $8.9 \times 10-1$ & $2.7 \times 10-1$ & 99.00 & $\begin{array}{c}\text { Althaus et al., } \\
2000\end{array}$ \\
\hline 49 & Bixad & nd & nd & nd & nd & nd & nd & nd & nd & nd & $\begin{array}{c}\text { Althaus et al., } \\
2000\end{array}$ \\
\hline 50 & Tusnad Nagy & nd & nd & nd & nd & nd & nd & nd & nd & nd & $\begin{array}{c}\text { Althaus et al., } \\
2000\end{array}$ \\
\hline 51 & $\begin{array}{c}\text { Balvanyos } \\
\text { Carpatii }\end{array}$ & nd & nd & nd & nd & nd & nd & nd & nd & nd & $\begin{array}{c}\text { Althaus et al., } \\
2000\end{array}$ \\
\hline 52 & Gyógyvizek & nd & nd & nd & nd & nd & nd & nd & nd & nd & $\begin{array}{c}\text { Unpublished } \\
\text { data }\end{array}$ \\
\hline 53 & Bancu & nd & nd & nd & nd & $\begin{array}{c}1.0 \\
\times 10-5\end{array}$ & $7.0 \times 10-1$ & $2.4 \mathrm{E}+00$ & $2.0 \times 10-1$ & 95.88 & $\begin{array}{c}\text { Unpublished } \\
\text { data }\end{array}$ \\
\hline 54 & Lazaresti & nd & nd & nd & nd & nd & $8.5 \times 10-1$ & $2.0 \mathrm{E}+00$ & $1.8 \times 10-1$ & 96.4 & $\begin{array}{c}\text { Unpublished } \\
\text { data }\end{array}$ \\
\hline
\end{tabular}

Note. $\mathrm{Nd}=$ not determined

(C) 2019 American Geophysical Union. All rights reserved. 
Table 3. Isotopic composition of the gas samples.

\begin{tabular}{|c|c|c|c|c|c|c|c|c|c|c|}
\hline No. & Site & Campaign & Laboratory & $\begin{array}{c}\mathrm{R} / \mathrm{Ra} \\
\text { measured }\end{array}$ & $\begin{array}{c}\mathrm{R} / \mathrm{Ra} \\
\text { corrected }\end{array}$ & $4 \mathrm{He} / 20 \mathrm{Ne}$ & $\delta 13 \mathrm{C}-\mathrm{CO}_{2}$ & $\delta 18 \mathrm{O}-\mathrm{CO}_{2}$ & $\mathrm{CO}_{2} / 3 \mathrm{He}$ & Source \\
\hline \multirow[t]{2}{*}{1} & $\begin{array}{l}\text { Torjai Stinky } \\
\text { Cave }\end{array}$ & 1st Campaign & Debrecen & 2.67 & 2.69 & 18.07 & -3.24 & -6.74 & $3.29 \mathrm{E}+10$ & this work \\
\hline & 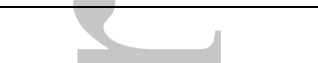 & 2nd Campaign & Palermo & 3.01 & 3.01 & 955.55 & -3.09 & nd & $3.24 \mathrm{E}+10$ & this work \\
\hline \multirow[t]{2}{*}{2} & Timsós cave & 1st Campaign & Debrecen & 2.71 & 2.73 & 23.83 & -3.36 & -6.08 & $3.17 \mathrm{E}+10$ & this work \\
\hline & 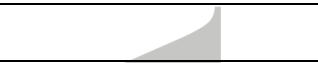 & 2nd Campaign & Palermo & 2.90 & 2.95 & 13.20 & -3.47 & nd & $3.69 \mathrm{E}+10$ & this work \\
\hline 3 & Gyilkos cave & 1st Campaign & Debrecen & 2.12 & 2.40 & 1.40 & -3.22 & -6.63 & nd & this work \\
\hline \multirow[t]{2}{*}{4} & $\begin{array}{c}\text { Buffogó peat bog } \\
\text { pool }\end{array}$ & 1st Campaign & Debrecen & 2.86 & 2.86 & 758.43 & -2.70 & -9.00 & $2.45 \mathrm{E}+10$ & this work \\
\hline & & 2nd Campaign & Palermo & 2.27 & 2.95 & 0.90 & -3.15 & nd & $3.27 \mathrm{E}+10$ & this work \\
\hline 5 & Buffogó peat bog & 1st Campaign & Debrecen & 1.78 & 1.78 & 477.09 & nd & nd & nd & this work \\
\hline 6 & $\begin{array}{c}\text { Várpad - Ibolya } \\
\text { pool }\end{array}$ & 1st Campaign & Debrecen & 1.49 & 2.43 & 0.44 & -3.13 & nd & $3.81 \mathrm{E}+11$ & this work \\
\hline $7 \mathrm{a}$ & $\begin{array}{c}\text { Bálványos } \\
\text { mofetta }\end{array}$ & 1st Campaign & Debrecen & 1.13 & 1.13 & 456.45 & nd & nd & nd & this work \\
\hline \multirow[t]{2}{*}{$7 b$} & $\begin{array}{c}\text { Bálványos } \\
\text { mofetta }\end{array}$ & 1st Campaign & Debrecen & 2.06 & 2.19 & 2.62 & -4.20 & nd & $6.71 \mathrm{E}+10$ & this work \\
\hline & 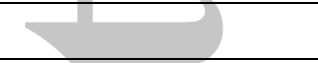 & 2nd Campaign & Palermo & 2.06 & 2.15 & 4.0 & -17.20 & nd & nd & this work \\
\hline 8 & Bálványos pool & 1st Campaign & Debrecen & 2.14 & 2.17 & 9.75 & -2.84 & nd & $1.26 \mathrm{E}+10$ & this work \\
\hline \multirow[t]{2}{*}{9} & $\begin{array}{l}\text { Csiszárfürdö - } \\
\text { Iker pool white }\end{array}$ & 1st Campaign & Debrecen & 2.43 & 2.44 & 127.86 & -3.06 & -7.44 & nd & this work \\
\hline & 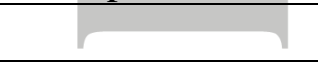 & 2nd Campaign & Palermo & 2.81 & 2.82 & 90.4 & nd & nd & $2.53 \mathrm{E}+10$ & this work \\
\hline 10 & $\begin{array}{l}\text { Csiszárfürdő - } \\
\text { Hammas pool }\end{array}$ & 1st Campaign & Debrecen & 1.97 & 1.97 & 1695.21 & -3.59 & -8.40 & $3.23 \mathrm{E}+10$ & this work \\
\hline 10 & & 2nd Campaign & Palermo & 2.90 & 2.90 & 123.8 & -3.20 & nd & $3.43 \mathrm{E}+10$ & this work \\
\hline 11 & $\begin{array}{l}\text { Csiszárfürdő - } \\
\text { Timsós pool }\end{array}$ & 1st Campaign & Debrecen & 2.46 & 3.09 & 0.95 & -2.47 & nd & $2.33 \mathrm{E}+09$ & this work \\
\hline 12 & Csiszárfürdő - & 1st Campaign & Debrecen & 2.44 & 2.90 & 1.21 & -3.40 & nd & $2.37 \mathrm{E}+10$ & this work \\
\hline
\end{tabular}

(c) 2019 American Geophysical Union. All rights reserved. 


\begin{tabular}{|c|c|c|c|c|c|c|c|c|c|c|}
\hline & Csokoládés pool & & & & & & & & & \\
\hline 12 & 0 & 2nd Campaign & Palermo & 2.90 & 2.91 & 55.00 & -2.60 & nd & $2.68 \mathrm{E}+10$ & this work \\
\hline 13 & $\begin{array}{l}\text { Mikesfürdő - } \\
\text { Vallató pool }\end{array}$ & 1st Campaign & Debrecen & 2.72 & 2.73 & 52.98 & -2.28 & -6.87 & $2.42 \mathrm{E}+10$ & this work \\
\hline 13 & 8 & 2nd Campaign & Palermo & 2.55 & 2.57 & 31.4 & -2.30 & nd & $6.18 \mathrm{E}+10$ & this work \\
\hline 14 & $\begin{array}{c}\text { Mikesfürdő - } \\
\text { Vallató mofetta }\end{array}$ & 1st Campaign & Debrecen & 2.21 & 2.25 & 7.43 & -2.45 & -6.37 & $9.87 \mathrm{E}+10$ & this work \\
\hline 15 & $\begin{array}{l}\text { Mikesfürdő - } \\
\text { Hammas pool }\end{array}$ & 1st Campaign & Debrecen & 2.74 & 2.74 & 266.70 & -3.35 & -7.09 & $3.19 \mathrm{E}+10$ & this work \\
\hline 15 & $<>1$ & 2nd Campaign & Palermo & 3.02 & 3.03 & 74.0 & -2.90 & nd & $3.85 \mathrm{E}+10$ & this work \\
\hline 16 & $\begin{array}{l}\text { Mikesfürdö - } \\
\text { Bükkös pool }\end{array}$ & 1st Campaign & Debrecen & 2.46 & 2.93 & 1.19 & -2.65 & nd & $2.52 \mathrm{E}+10$ & this work \\
\hline 16 & & 2nd Campaign & Palermo & 1.98 & 2.16 & 2.0 & -3.20 & nd & $3.64 \mathrm{E}+10$ & this work \\
\hline 17 & $\begin{array}{c}\text { Apor lányok } \\
\text { feredeje - Small } \\
\text { pool }\end{array}$ & 1st Campaign & Debrecen & 1.99 & 1.99 & 233.48 & -3.09 & -5.13 & $1.81 \mathrm{E}+10$ & this work \\
\hline 17 & $\square$ & 2nd Campaign & Palermo & 2.81 & 2.86 & 12.8 & nd & nd & $2.95 \mathrm{E}+10$ & this work \\
\hline 18 & $\begin{array}{l}\text { Apor lányok } \\
\text { feredeje -spring } \\
\text { on fault } 2\end{array}$ & 1st Campaign & Debrecen & 3.10 & 3.15 & 11.80 & -3.85 & nd & $2.87 \mathrm{E}+10$ & this work \\
\hline 18 & $Y$ & 2nd Campaign & Palermo & 2.90 & 2.90 & 836.3 & -4.00 & nd & $3.68 \mathrm{E}+10$ & this work \\
\hline 19 & $\begin{array}{c}\text { Apor lányok } \\
\text { feredeje -Szemvíz } \\
4 \\
\end{array}$ & 1st Campaign & Debrecen & 1.85 & 1.85 & 425.84 & -3.52 & -2.79 & $1.20 \mathrm{E}+10$ & this work \\
\hline 19 & $\square$ & 2nd Campaign & Palermo & 1.34 & 1.50 & 1.00 & -2.60 & nd & nd & this work \\
\hline 20 & Gyógyvizek & 1st Campaign & Debrecen & 2.73 & 2.73 & 497.01 & -3.42 & -4.58 & $3.17 \mathrm{E}+10$ & this work \\
\hline 20 & & 2nd Campaign & Palermo & 1.46 & 1.73 & 0.9 & -3.30 & nd & $4.37 \mathrm{E}+10$ & this work \\
\hline 21 & $\begin{array}{c}\text { Bálványos } \\
\text { Sósmező drilling } \\
1\end{array}$ & 1st Campaign & Debrecen & 0.78 & 0.27 & 0.41 & -4.61 & -5.44 & $8.13 \mathrm{E}+11$ & this work \\
\hline
\end{tabular}

(c) 2019 American Geophysical Union. All rights reserved. 


\begin{tabular}{|c|c|c|c|c|c|c|c|c|c|c|}
\hline 22 & $\begin{array}{c}\text { Bálványos } \\
\text { Sósmező drilling } \\
2\end{array}$ & 1st Campaign & Debrecen & 0.82 & 0.72 & 0.82 & -4.37 & -5.30 & $1.82 \mathrm{E}+11$ & this work \\
\hline 23 & $\begin{array}{c}\text { Bálványos } \\
\text { Sósmező drilling } \\
3 \\
\end{array}$ & 1st Campaign & Debrecen & 2.43 & 2.83 & 1.32 & -3.92 & nd & nd & this work \\
\hline 24 & St Anna crater rim & 1st Campaign & Debrecen & 1.99 & 2.58 & 0.78 & -2.80 & -9.05 & $7.78 \mathrm{E}+09$ & this work \\
\hline 25 & Jajdon pool & 1st Campaign & Debrecen & 2.30 & 2.83 & 0.99 & -3.41 & nd & $5.02 \mathrm{E}+09$ & this work \\
\hline 26 & Jajdon mofetta & 1st Campaign & Debrecen & 1.45 & 3.25 & 0.36 & -3.96 & nd & $4.51 \mathrm{E}+09$ & this work \\
\hline 27 & $\begin{array}{l}\text { Băile Tuşnad } \\
\text { mofetta }\end{array}$ & 1st Campaign & Debrecen & 2.02 & 2.32 & 1.28 & -1.50 & nd & $7.48 \mathrm{E}+10$ & this work \\
\hline 28 & $\begin{array}{c}\text { Lăzărești } \\
\text { Nyírfürdő mofetta }\end{array}$ & 1st Campaign & Debrecen & 1.43 & 1.45 & 6.50 & -2.08 & nd & $3.84 \mathrm{E}+11$ & this work \\
\hline 29 & $\begin{array}{c}\text { Lăzăressti } \\
\text { Nyírfürdő pool }\end{array}$ & 1st Campaign & Debrecen & 1.11 & 1.46 & 0.38 & -1.40 & nd & $1.24 \mathrm{E}+11$ & this work \\
\hline 29 & 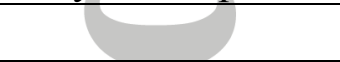 & 2nd Campaign & Palermo & 1.01 & 1.01 & 40.2 & -1.50 & nd & $6.45 \mathrm{E}+11$ & this work \\
\hline 30 & $\begin{array}{c}\text { Lăzărești } \\
\text { Nyírfürdő pool } 2 \\
\end{array}$ & 1st Campaign & Debrecen & 1.30 & 1.32 & 4.69 & -1.91 & nd & $4.13 \mathrm{E}+11$ & this work \\
\hline 31 & $\begin{array}{l}\text { Ciucsângeorgiu } \\
\text { mofetta }\end{array}$ & 1st Campaign & Debrecen & 0.77 & 0.14 & 0.39 & -2.95 & nd & $5.50 \mathrm{E}+10$ & this work \\
\hline 32 & $\begin{array}{c}\text { Csiszárfürdő Băile } \\
\text { Reci }\end{array}$ & & & 0.796 & 0.796 & 0.99 & nd & nd & $3.89 \mathrm{E}+10$ & $\begin{array}{c}\text { Frunzeti, } \\
2013 \\
\end{array}$ \\
\hline 33 & $\begin{array}{c}\text { Gyógyvizek } \\
\text { Izvoarele } \\
\text { Tămăduitoare }\end{array}$ & & & 2.302 & 2.302 & 766.09 & -3.25 & -7.43 & $8.62 \mathrm{E}+09$ & $\begin{array}{c}\text { Frunzeti, } \\
2013\end{array}$ \\
\hline 34 & $\begin{array}{l}\text { Apor lányok } \\
\text { feredeje }\end{array}$ & & & 2.438 & 2.438 & 2686.92 & -3.72 & -4.92 & $8.17 \mathrm{E}+09$ & $\begin{array}{c}\text { Frunzeti, } \\
2013 \\
\end{array}$ \\
\hline 35 & $\begin{array}{c}\text { Torjai Büdös } \\
\text { Cave (Stinky } \\
\text { Cave) }\end{array}$ & & & 2.199 & 2.199 & 583.84 & -3.15 & -7.48 & $1.17 \mathrm{E}+10$ & $\begin{array}{c}\text { Frunzeti, } \\
2013\end{array}$ \\
\hline 36 & Mikesfürdő- & & & 2.242 & 2.242 & 656.89 & -3.16 & -9.87 & $9.47 \mathrm{E}+09$ & Frunzeti, \\
\hline
\end{tabular}

() 2019 American Geophysical Union. All rights reserved. 


\begin{tabular}{|c|c|c|c|c|c|c|c|c|}
\hline & Hammas & & & & & & & 2013 \\
\hline 37 & Buffogó peat bog & 2.274 & 2.274 & 2711.03 & -2.77 & -9.21 & $8.31 \mathrm{E}+09$ & $\begin{array}{c}\text { Frunzeti, } \\
2013\end{array}$ \\
\hline 38 & Tusnad & 0.724 & 0.724 & 9.79 & -4.7 & -8.2 & $1.79 \mathrm{E}+12$ & $\begin{array}{c}\text { Frunzeti, } \\
2013\end{array}$ \\
\hline 39 & Tusnad Nadas & 1.66 & 1.66 & 1.28 & -4.42 & nd & $7.19 \mathrm{E}+12$ & $\begin{array}{l}\text { Vaselli et } \\
\text { al., } 2002\end{array}$ \\
\hline 40 & Lăzărești Nyir & 2.95 & 2.95 & 7.7 & nd & nd & $2.79 \mathrm{E}+10$ & $\begin{array}{l}\text { Vaselli et } \\
\text { al., } 2002\end{array}$ \\
\hline 41 & Sf Anna & 3.18 & 3.18 & 25 & nd & nd & $3.20 \mathrm{E}+10$ & $\begin{array}{l}\text { Vaselli et } \\
\text { al., } 2002\end{array}$ \\
\hline 42 & Puturosul & 2.29 & 2.29 & 10.11 & nd & nd & $7.53 \mathrm{E}+10$ & $\begin{array}{l}\text { Vaselli et } \\
\text { al., } 2002\end{array}$ \\
\hline 43 & Puturosul Sud & nd & nd & nd & -4.7 & nd & nd & $\begin{array}{l}\text { Vaselli et } \\
\text { al., } 2002\end{array}$ \\
\hline 44 & Bálványos & 4.48 & 4.48 & 163 & nd & nd & $2.52 \mathrm{E}+10$ & $\begin{array}{l}\text { Vaselli et } \\
\text { al., } 2002\end{array}$ \\
\hline 45 & $\begin{array}{c}\text { Torjai Büdös } \\
\text { Cave (Stinky } \\
\text { Cave) }\end{array}$ & 3.1 & 3.100 & 47.3 & nd & nd & $2.07 \mathrm{E}+10$ & $\begin{array}{l}\text { Althaus et } \\
\text { al., } 2000\end{array}$ \\
\hline 46 & $\begin{array}{c}\text { Apor lányok } \\
\text { feredeje-Upper } \\
\text { pool }\end{array}$ & 3.12 & 3.120 & 151 & nd & nd & $1.72 \mathrm{E}+10$ & $\begin{array}{l}\text { Althaus et } \\
\text { al., } 2000\end{array}$ \\
\hline 47 & $\begin{array}{c}\text { Apor lányok } \\
\text { feredeje-Lower } \\
\text { pool }\end{array}$ & 3.19 & 3.190 & 712 & nd & nd & $1.70 \mathrm{E}+10$ & $\begin{array}{l}\text { Althaus et } \\
\text { al., } 2000\end{array}$ \\
\hline 48 & Bixad & 1.47 & 1.470 & 0.67 & nd & nd & nd & $\begin{array}{l}\text { Althaus et } \\
\text { al., } 2000\end{array}$ \\
\hline 49 & Bixad & 0.8 & 0.8 & 1.3 & nd & nd & nd & $\begin{array}{c}\text { Althaus et } \\
\text { al., } 2000\end{array}$ \\
\hline 50 & Tusnad Nagy & 1.2 & 1.2 & 6.44 & nd & nd & nd & Althaus et \\
\hline
\end{tabular}

(c) 2019 American Geophysical Union. All rights reserved. 


\begin{tabular}{|c|c|c|c|c|c|c|c|c|}
\hline & & & & & & & & al., 2000 \\
\hline 51 & $\begin{array}{c}\text { Balvanyos } \\
\text { Carpatii }\end{array}$ & 3.04 & 3.04 & 1.06 & nd & nd & nd & $\begin{array}{c}\text { Althaus et } \\
\text { al., } 2000\end{array}$ \\
\hline
\end{tabular}

Note. ${ }^{3} \mathrm{He} /{ }^{4} \mathrm{He}$ ratios are normalized to the atmosphere and listed as $\mathrm{R} / \mathrm{R}_{\mathrm{a}}$ values corrected for the atmospheric He contamination $\left(\mathrm{R} / \mathrm{R}_{\mathrm{ac}}\right)$ considering the ${ }^{4} \mathrm{He} /{ }^{20} \mathrm{Ne}$ ratio; $\delta^{13} \mathrm{C}$ $\mathrm{CO}_{2}$ and $\delta^{18} \mathrm{O}-\mathrm{CO}_{2}$ are expressed in \%o vs. VPDB. $\mathrm{Nd}=$ not determined

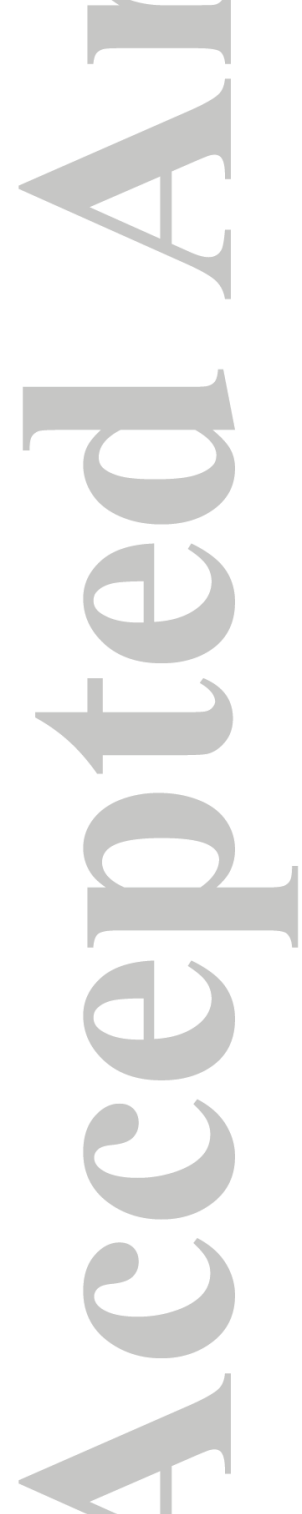


Table 4. Isotopic composition of Persani clinopyroxene.

\begin{tabular}{|l|l|l|l|l|l|l|}
\hline Sample & {$[\mathrm{He}] \mathrm{mol} / \mathrm{g}$} & {$[\mathrm{Ne}] \mathrm{mol} / \mathrm{g}$} & $\mathrm{He} / \mathrm{Ar}$ & ${ }^{4} \mathrm{He} /{ }^{20} \mathrm{Ne}$ & $\mathrm{R} / \mathrm{Ra}$ & $\mathrm{R} / \mathrm{Ra} \mathrm{c}$ \\
\hline Cpx xenolith & $4.06 \mathrm{E}-12$ & $2.00 \mathrm{E}-15$ & 0.92 & 2030.46 & 5.96 & 5.96 \\
\hline Cpx xenolith 2 & $3.81 \mathrm{E}-12$ & $2.74 \mathrm{E}-15$ & 0.91 & 1389.41 & 5.94 & 5.94 \\
\hline
\end{tabular}

Note. ${ }^{3} \mathrm{He} /{ }^{4} \mathrm{He}$ ratios are normalized to the atmosphere and listed as $\mathrm{R} / \mathrm{R}_{\mathrm{a}}$ values $\left(\mathrm{R}={ }^{3} \mathrm{He} /{ }^{4} \mathrm{He}\right.$ isotopic ratio of the sample, $\left.\mathrm{R}_{\mathrm{a}}=\mathrm{atmospheric}{ }^{3} \mathrm{He} /{ }^{4} \mathrm{He}=1.382 \times 10^{-6}\right)$ and corrected for the atmospheric helium contamination $\left(\mathrm{R} / \mathrm{R}_{\mathrm{ac}}\right)$ considering the ${ }^{4} \mathrm{He} /{ }^{20} \mathrm{Ne}$ ratio;

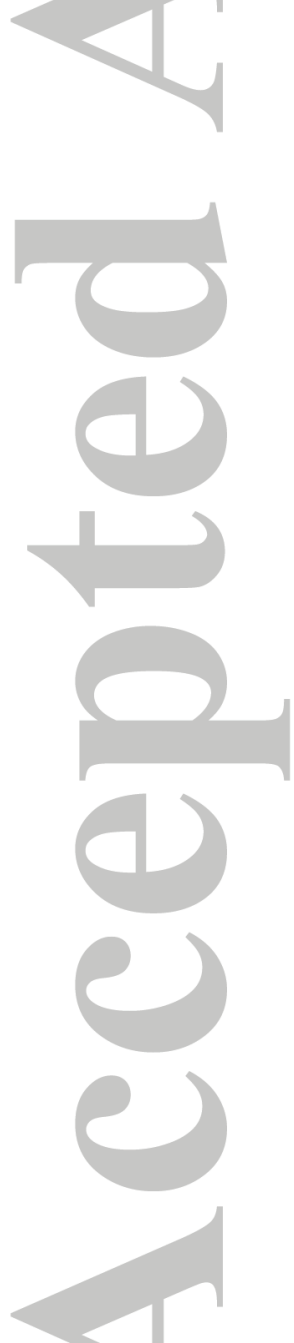



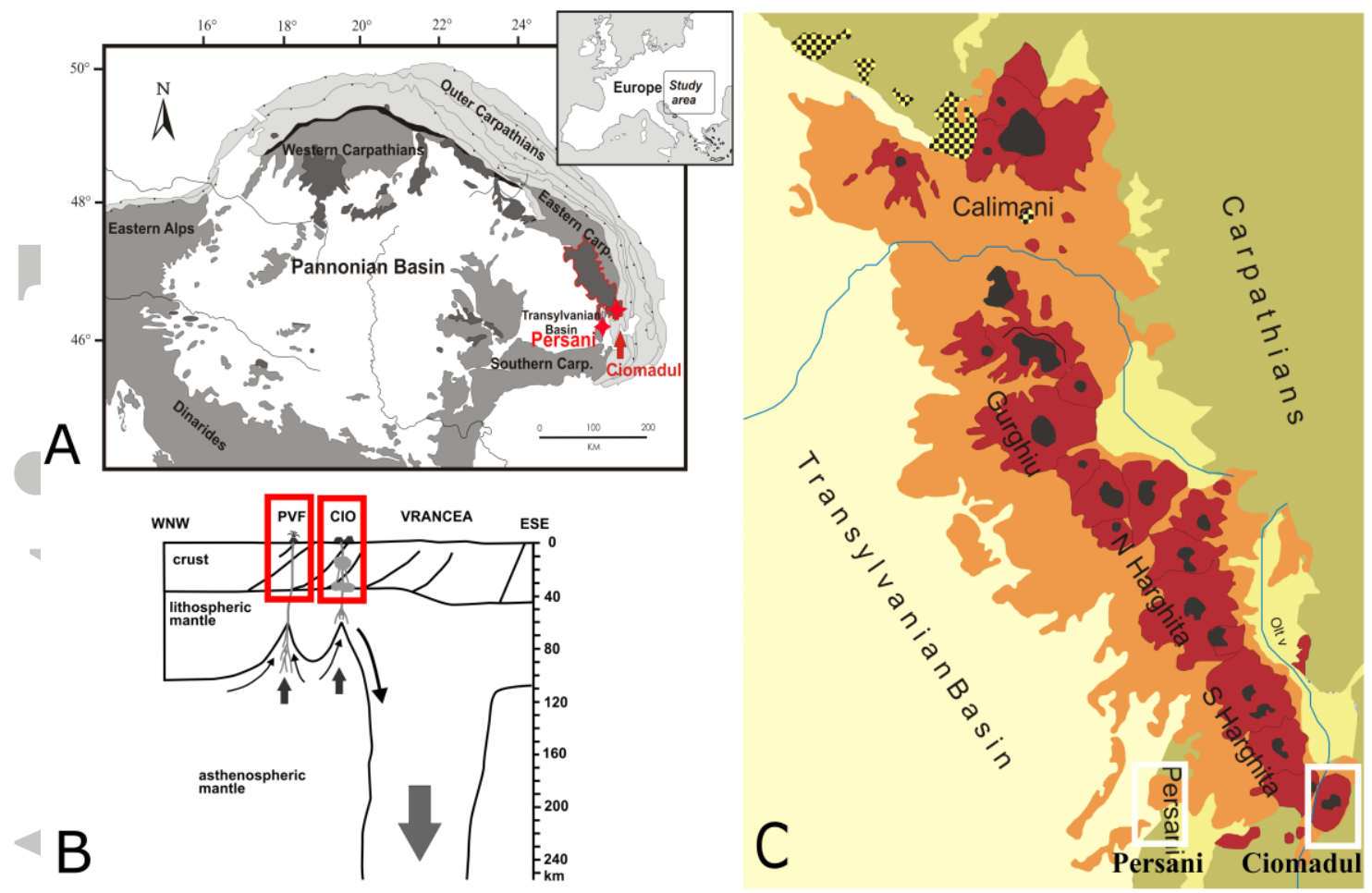

B

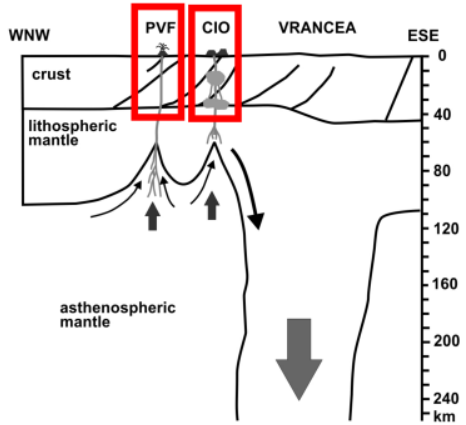

Persāni Ciomadul

Figure 1a: Location of Ciomadul and Persani volcanoes in the southeastern Carpathian area of the CarpathianPannonian Region (after Harangi et al., 2013), 1b: Geotectonic model of the Persani and Ciomadul volcanic areas, PVF=Persani Volcanic Field, CIO=Ciomadul (after Harangi et al., 2013), 1c: Location of Ciomadul and Persani volcanoes in the volcanic range of the Eastern Carpathians (modified after Szakács \& Seghedi, 1995) 


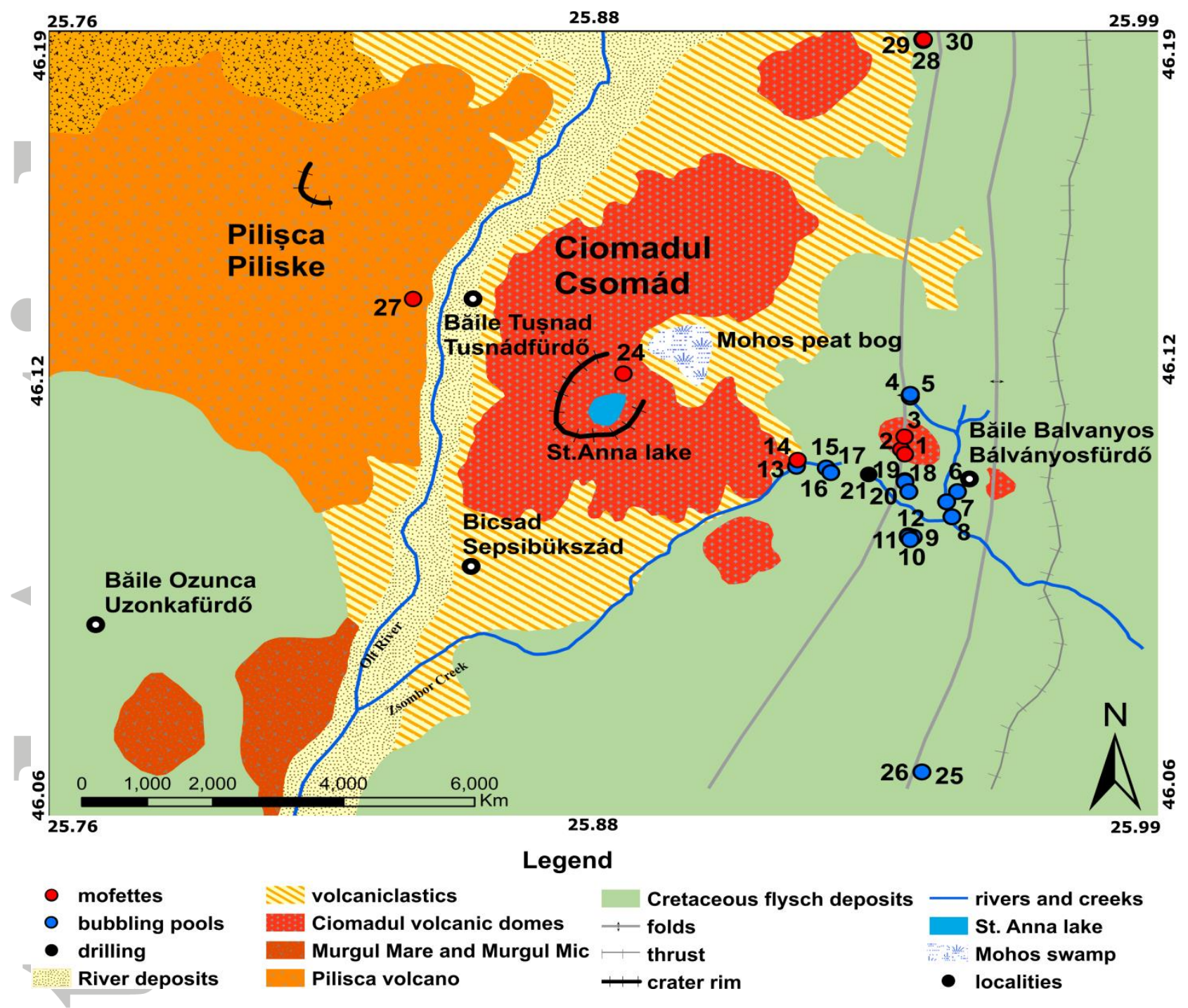

Figure 2: Geological sketch map of the study area. The red, black and blue dots indicate the type of the sampling points: mofette, drilling and bubbling pool respectively. The numbers on the sampling sites are the same as in Tables 1. (Geological map is modified after Ianovici \& Radulescu, 1968) 


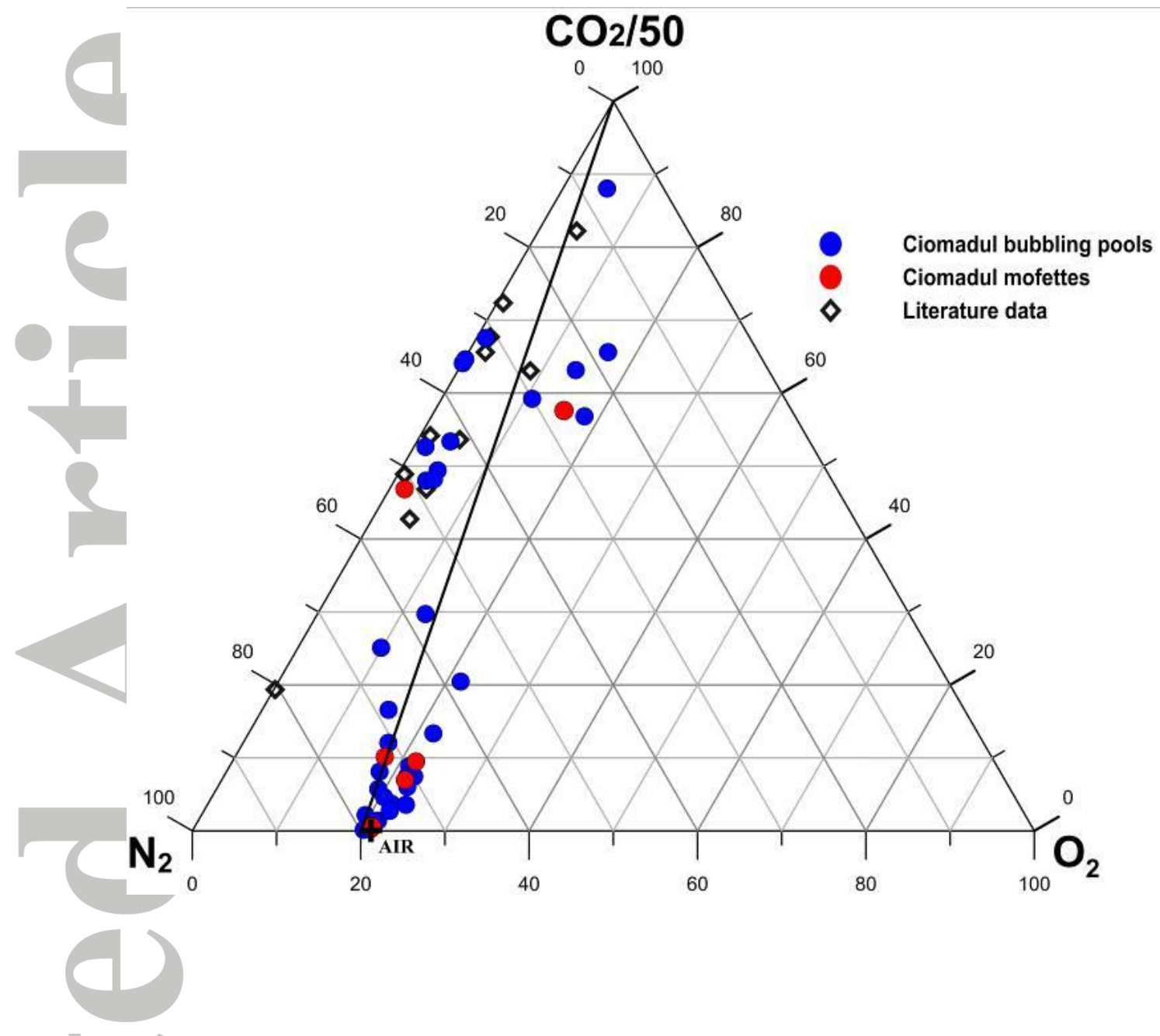

Figure 3: $\mathrm{CO}_{2} / 50-\mathrm{O}_{2}-\mathrm{N}_{2}$ triangular diagram showing the relative contents of components. The samples distribution highlights mixing between $\mathrm{CO}_{2}$ and atmospheric gas species. Literature data from Ciomadul area is represented by data from Althaus et al., 2000; Vaselli et al., 2002; Frunzeti, 2013). 


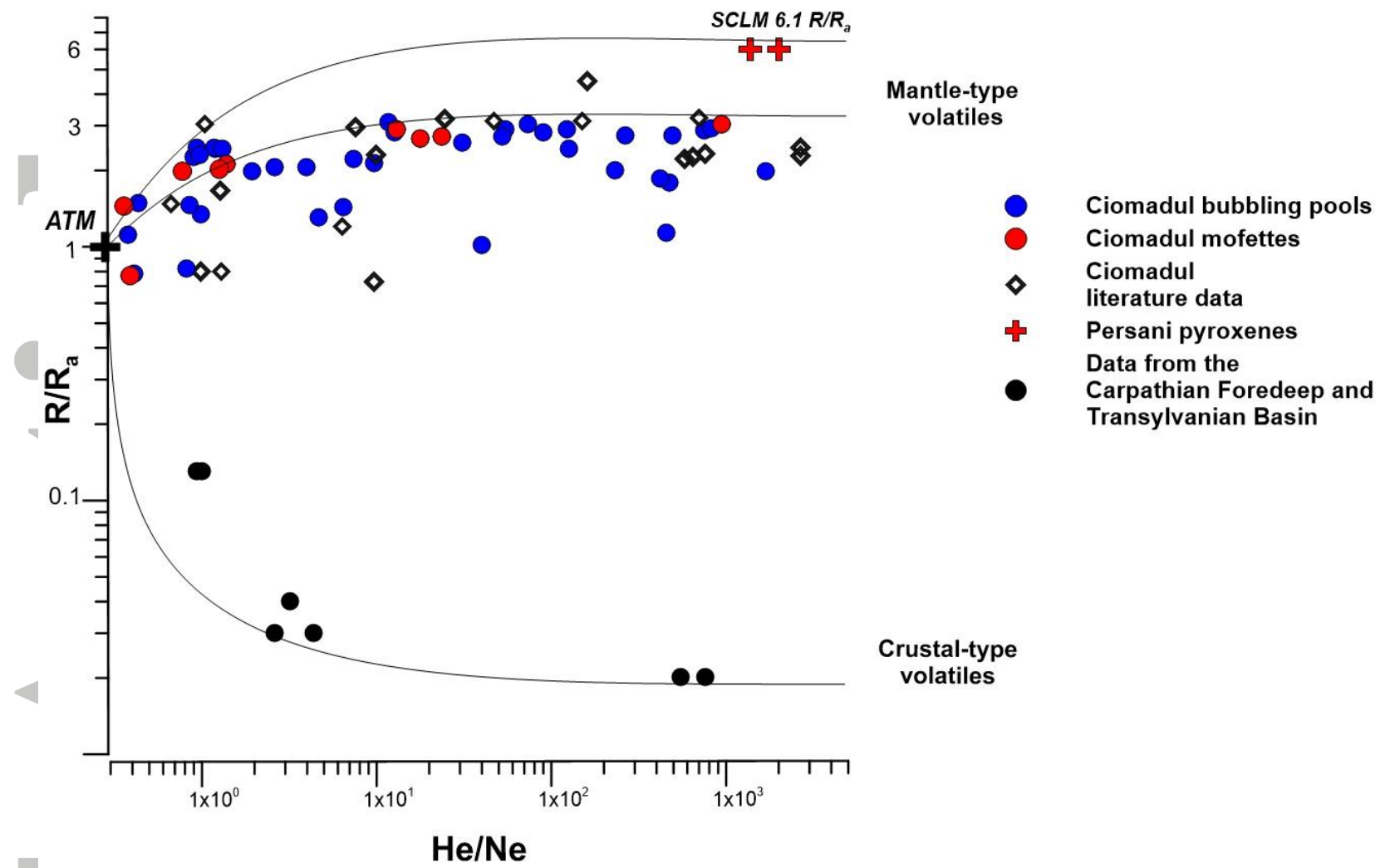

Figure 4: Helium isotopic ratios $\left(\mathrm{R} / \mathrm{R}_{\mathrm{a}}\right.$ values) and ${ }^{4} \mathrm{He} /{ }^{20} \mathrm{Ne}$ relationships. The theoretical lines represent binary mixings of atmospheric He with mantle-originated and crustal He (Pik \& Marty, 2008). The assumed end members for He-isotopic ratios and ${ }^{4} \mathrm{He} /{ }^{20} \mathrm{Ne}$ ratios are: $\mathrm{ATM}\left(1 \mathrm{R}_{\mathrm{a}}, \mathrm{He} / \mathrm{Ne}=0.318\right.$, Sano and Wakita 1985).; Subcontinental European Mantle $\left(6.1 \pm 0.9 \mathrm{R}_{\mathrm{a}}\right.$ and ${ }^{4} \mathrm{He} /{ }^{20} \mathrm{Ne}$ ratio=1000; Gautheron and Moreira, 2002); typical crustal end-member is $0.02 \mathrm{R}_{\mathrm{a}}$ and ${ }^{4} \mathrm{He} /{ }^{20} \mathrm{Ne}$ ratio $=1000$ (Sano and Marty, 1995). Literature data for comparison: data after Althaus et al. 2000; Vaselli et al. 2002; Baciu et al., 2007; 2017; Frunzeti et al., 2013). 


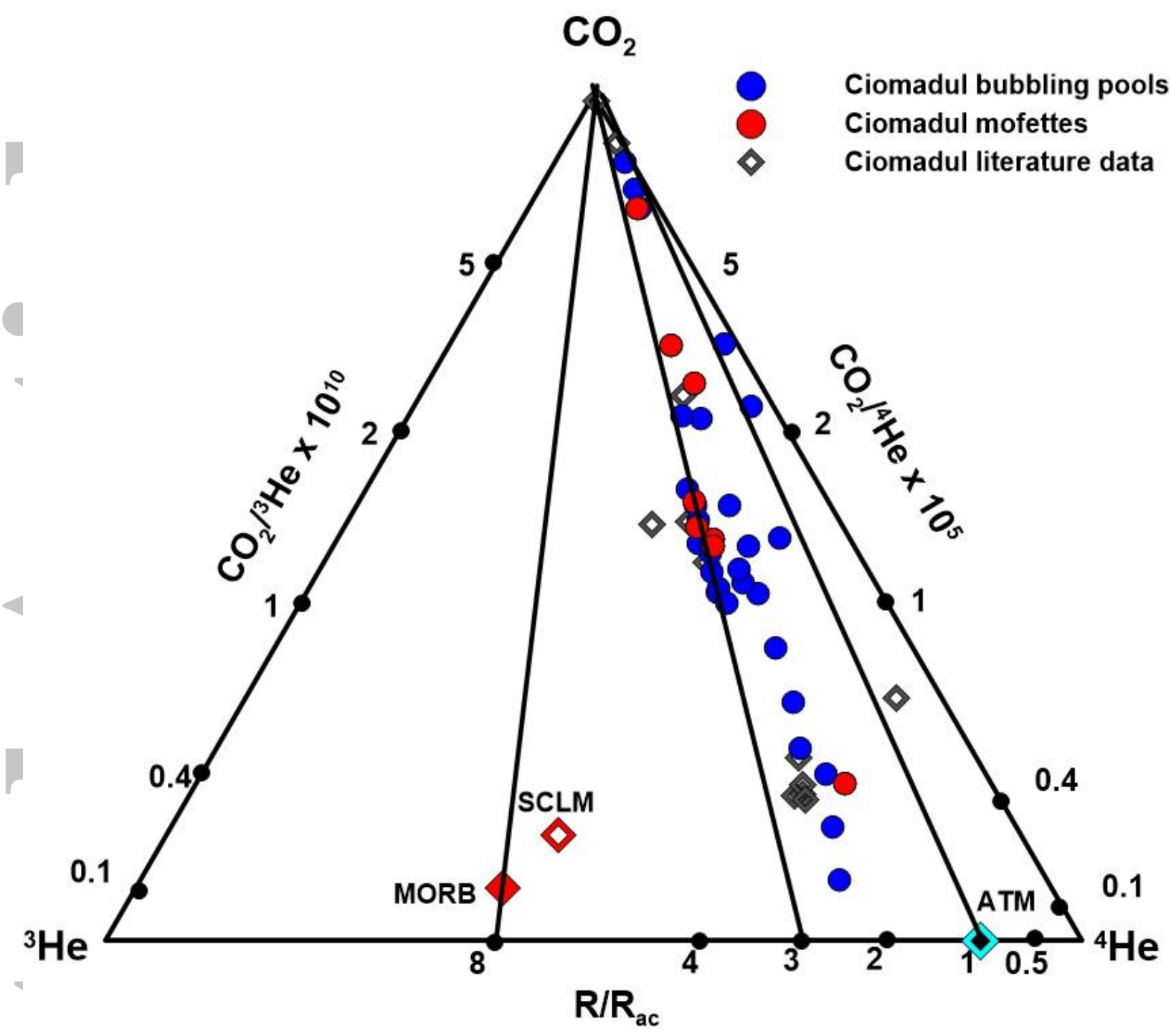

Figure 5: Ternary $\mathrm{CO}_{2}-{ }^{3} \mathrm{He}-{ }^{4} \mathrm{He}$ diagram of Ciomadul gas samples.Ciomadul literature data after Althaus et al. 2000, Vaselli et al. 2002, Frunzeti et al., 2013. For reference, we have plotted the MORB (Marty \& Jambon, 1987 ) and SCLM values (Gautheron and Moreira, 2002) 


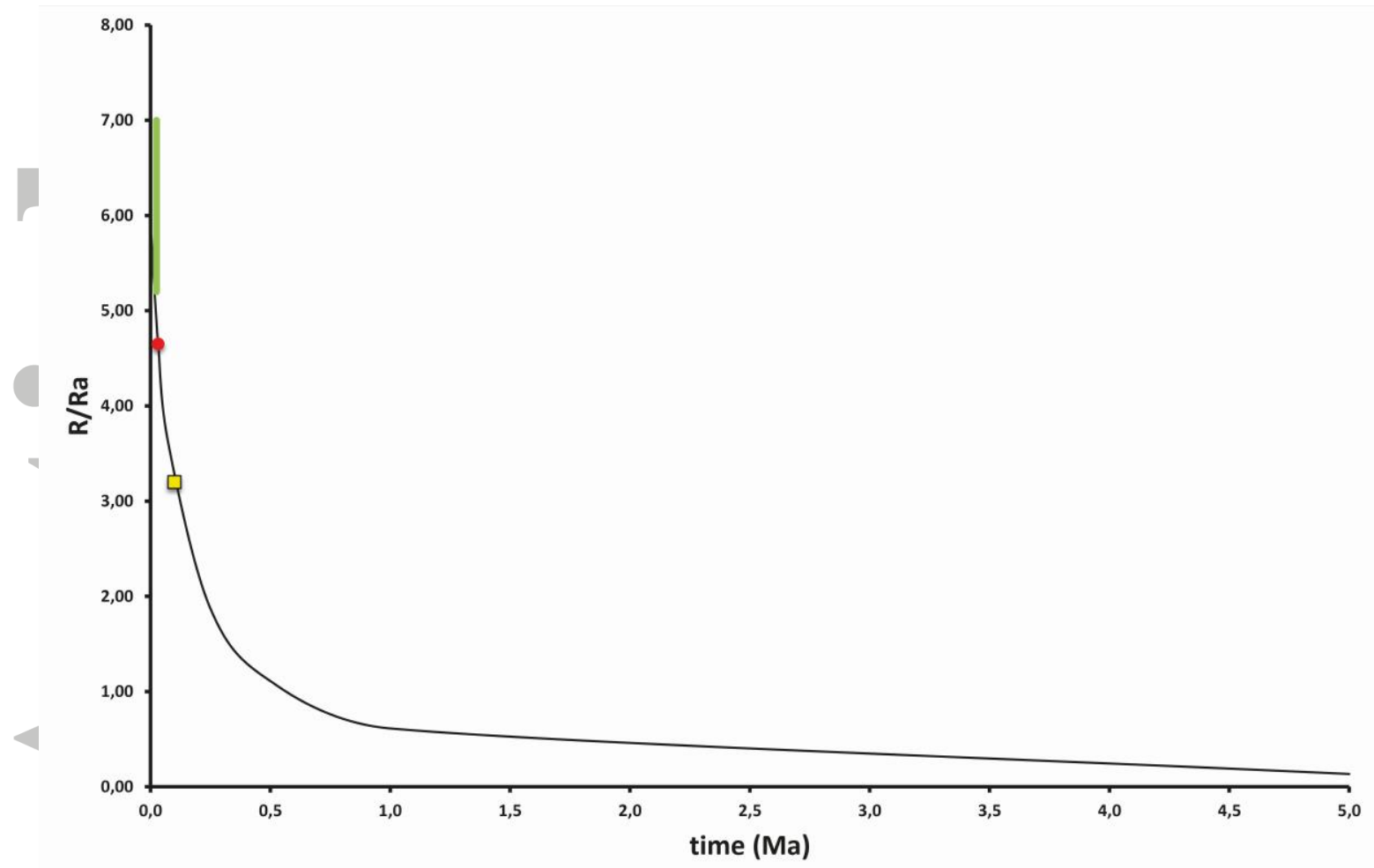

Figure 6 Magma aging evolution over time of the He isotopic signature (as $\left.R / R_{a}\right)$. The green bar is the range of the SCLM He isotopic ratio (6.1 \pm 0.9 ; Gautheron and Moreira, 2002). The red circle is the value or the ${ }^{3} \mathrm{He} /{ }^{4} \mathrm{He}$ (4.65Ra) at $30 \mathrm{ka}$ for the magma aging evolution. ${ }^{3} \mathrm{He} /{ }^{4} \mathrm{He}=3.2$ is at $100 \mathrm{ka}$ (yellow square). 


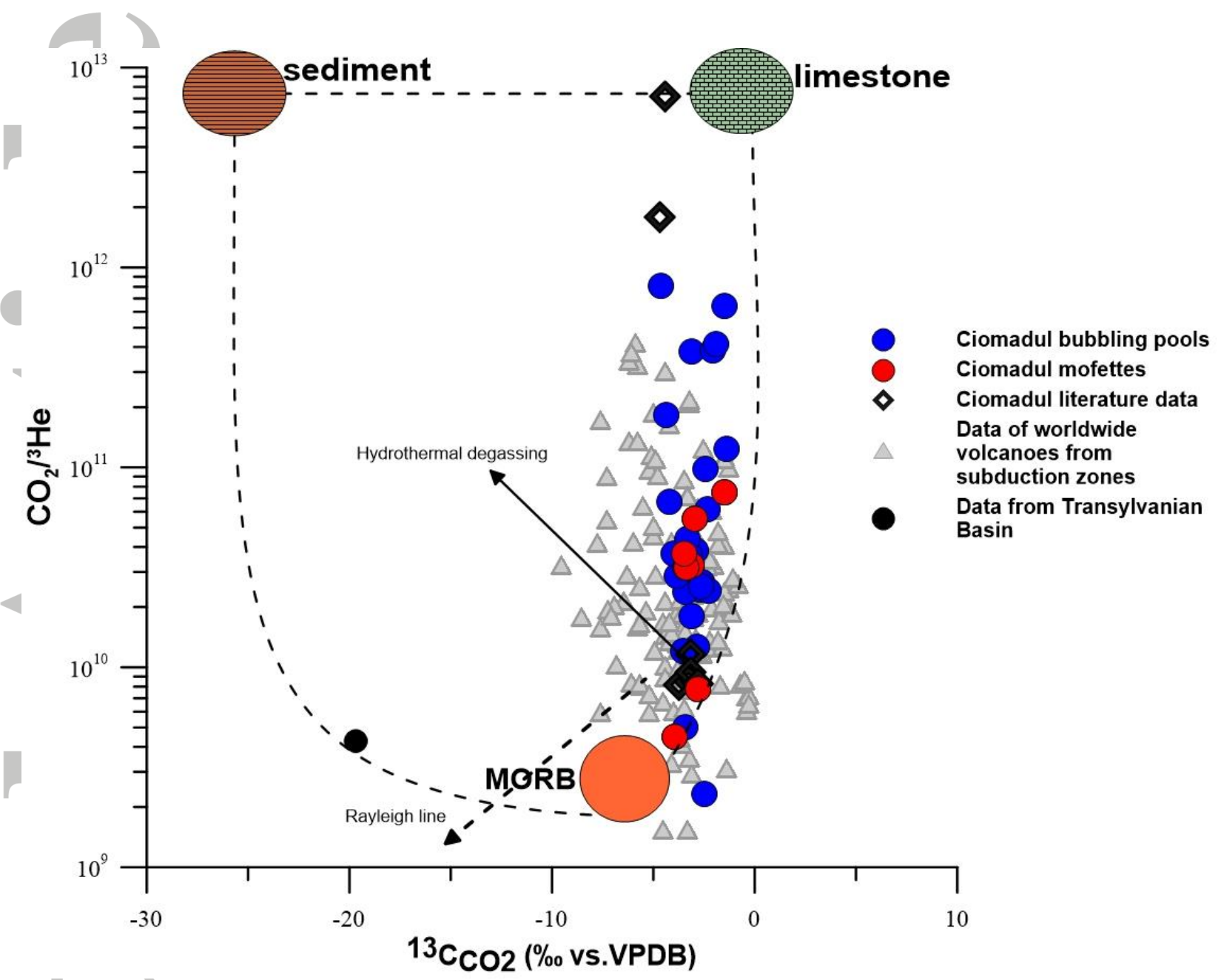

Figure 7: Correlation diagram of Sano and Marty (1995) plotting $\mathrm{CO}_{2} /{ }^{3} \mathrm{He}$ vs. ${ }^{13} \mathrm{C}_{\mathrm{CO} 2}$ (VPDB) of Ciomadul gas emissions. Lines show the theoretical mixing between a mantle end-member and a crustal end-member represented by marine limestone and organic sediment carbon. Ciomadul samples are showing a trend of mixing between fluids of mantle origin and fluids originating from limestone. Literature data for comparison: data after Althaus et al. 2000; Vaselli et al. 2002; Baciu et al., 2007; 2017; Frunzeti et al., 2013.

Data on individual volcanoes worldwide based on the compilation of Mason et al. (2017), by Allard, 1983; Marty \& Giggenbach, 1990; Poorter et al., 1991; Varekamp et a., 1992; Sturchio et al., 1993; Sano et al., 1994; Sano \& Marty, 1995; Tedesco et al., 1995;Hilton, 1996;Sano\&Williams, 1996; Allard et al., 1997; Fischer et al., 1998; Van Soest et al., 1998; Pedroni et al., 1999; Lewicki et al., 2000; Parello et al., 2000; Favara et al., 2001; Snyder et al., 2001; Shaw et al., 2003; Symonds et al., 2003; Jaffe et al., 2004; Capasso et al, 2005b; Carapezza et al., 2007; de Leeuw et a., 2007; Werner et al., 2009; Capaccioni et al., 2011; Tassi et al., 2011; Aguilera. et al., 2012; Melian et al., 2012; Caracausi et al., 2013.

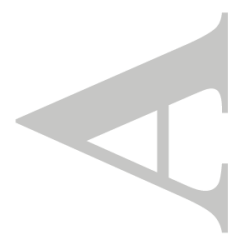



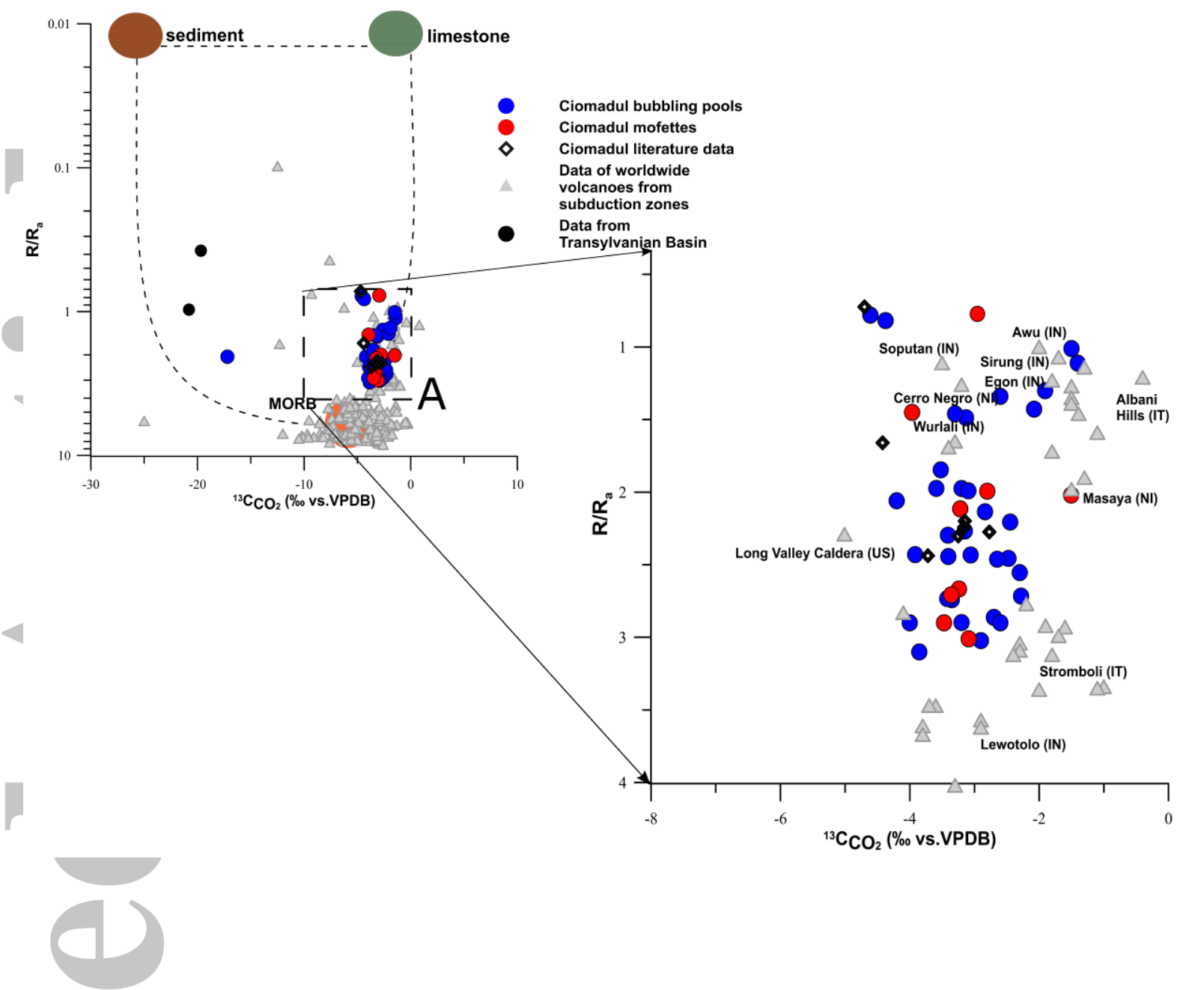

Figure 8a and b Correlation diagram (Ciotoli et al., 2013) plotting He isotopic ratios (R/R $\left.\mathrm{R}_{\mathrm{a}}\right) \mathrm{vs} .{ }^{13} \mathrm{C}_{\mathrm{CO} 2}(\mathrm{VPDB})$ of Ciomadul gas emissions. Lines show the theoretical mixing between a mantle end-member (MORB) and a crustal end-member represented by marine limestone and organic sediment carbon (Sano \& Marty, 1995, Sherwood Lollar, 1997). Literature data for comparison: data after Althaus et al. 2000; Vaselli et al. 2002; Baciu et al., 2007, 2017; Frunzeti et al., 2013. Data on individual volcanoes worldwide based on the compilation of Mason et al. (2017) from the data presented by Allard,., 1983; Marty \& Giggenbach, 1990; Poorter et al., 1991; Varekamp et al., 1992; Sturchio et al., 1993; Sano et al., 1994; Sano \& Marty, 1995; Tedesco et al., 1995; Hilton, 1996; Sano \&Williams, 1996; Allard et al., 1997; Fischer et al., 1998; Van Soest et al., 1998; Pedroni et al., 1999; Lewicki et al., 2000; Parello et al., 2000; Favara et al., 2001; Snyder et al., 2001; Shaw et al., 2003; Symonds et al., 2003; Jaffe et al., 2004; Capasso et al, 2005b; Carapezza et al., 2007; de Leeuw et al., 2007; Werner et al., 2009; Capaccioni et al., 2011; Tassi et al., 2011; Aguilera et al., 2012; Melian et al., 2012; Caracausi et al., 2013.

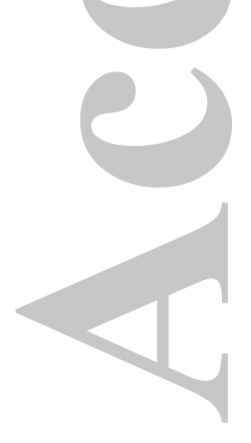

